\title{
Od przedstawień figuralnych do heraldycznych. Opaci lubiąscy i ich pieczęcie od schyłku średniowiecza do sekularyzacji klasztoru w 1810 roku*
}

Zarys treści: W niniejszym tekście przedstawiono analizę pieczęci opatów lubiąskich od schyłku średniowiecza do 1810 r. Zwrócono uwagę na stronę wizualną poszczególnych pieczęci opackich oraz funkcje, jakie pełniły one w działalności opatów w lokalnych wspólnotach oraz na zewnątrz. Artykuł został podzielony na część analityczną oraz inwentarz pieczęci opatów, w którym zestawiono wszystkie znane typariusze i odciski pieczętne z badanego okresu.

\begin{abstract}
The article presents an analysis of the seals of the Lubiąż (Leubus) abbots from the period between the end of the Middle Ages to 1810. Attention was paid to the visual aspects of individual abbot seals and the functions performed by the seals in the abbots' activity in both within the local communities and outside. The article is divided into an analytical part and an inventory of abbot seals, in which all known seal matrices and seals from the examined period are summarised.
\end{abstract}

Słowa kluczowe: pieczęcie opatów, cystersi, Lubiąż, Śląsk, sfragistyka kościelna, heraldyka kościelna

Keywords: abbatial seals, Cistercians, Lubiąż (Leubus), Silesia, ecclesiastical sigillography, ecclesiastical heraldry

Zdolność pieczęci do reprezentacji poprzez wprowadzenie wizerunku figuralnego albo bardziej symbolicznie poprzez herby pozwalała na tworzenie pożądanych wizerunków jednostek oraz poszczególnych grup społecznych. Pieczęcie przyczyniały się także do konstruowania ich tożsamości ${ }^{1}$.

W niniejszym tekście podjąłem się zbadania, w jaki sposób przedstawiano opatów cysterskich w Lubiążu na obrazach napieczętnych, ale także, do jakich celów te wizerunki służyły od późnego średniowiecza do czasów sekularyzacji klasztoru w 1810 r. Prześledziłem również okoliczności wprowadzenia pieczęci po wyborze nowego opata. Ważne było też ustalenie, czy wszystkie typariusze były każdorazowo wymieniane przez kolejnych opatów oraz jaki był czas ich stosowania. W pierwszej kolejności przeanalizowałem statuty kapituły generalnej z okresu nowożytnego, które mogły wpłynąć na

\footnotetext{
* Praca jest efektem pobytu stypendialnego DAAD w Uniwersytecie Alexandra von Humboldta w Berlinie w 2016 r. oraz realizacji projektu badawczego o $\mathrm{nr}$ 2017/01/X/HS3/00268 finansowanego ze środków Narodowego Centrum Nauki w latach 2017-2018.

${ }^{1}$ Omówienie badań w języku polskim w tym zakresie zob. T. Kałuski, Badania nad wizualnościa pieczęci w Europie Zachodniej $i$ w Polsce. Główne kierunki i nowe możliwości interpretacji, „Сфрагістичний щорічник”, 3, 2012, s. 262-270; tenże, Pieczęcie cechów na ziemiach księstwa głogowskiego do połowy XIX wieku. Geneza i symbolika, Warszawa 2013, s. 55-59.
} 
kształtowanie się obrazu opata ${ }^{2}$, podobnie jak to miało miejsce w średniowieczu ${ }^{3}$. W statutach podejmowano jednak tylko kwestie związane ze sprawowaniem pieczy nad pieczęciami opatów i konwentów oraz właściwego ich zastosowania przy dokumentach ${ }^{4}$. Uchwała opata generalnego Andochiusza Pernota z 1733 r. skierowana do opatów śląskich dotyczyła również m.in. losów pieczęci po zmarłym opacie $^{5}$. W mniejszym stopniu zatem niż dla okresu średniowiecza można wykorzystać wymienione postanowienia do badań nad obrazem napieczętnym.

Nowożytne pieczęcie opatów lubiąskich nie doczekały się do tej pory szczegółowego omówienia. Wybór klasztoru lubiąskiego na przedmiot analiz jest też istotny jako zasadniczy krok w kierunku przedstawienia w przyszłych badaniach wzajemnych relacji na płaszczyźnie wizualnej między wymienionym klasztorem a jego filiami, m.in. w odniesieniu do pieczęci opatów w późnym średniowieczu oraz w czasach nowożytnych. Powinno to zaowocować wnioskami równie interesującymi jak podjęte już przeze mnie w innym miejscu rozważania dotyczące pieczęci opatów z klasztoru lubiąskiego i przełożonych jego filii oraz innych klasztorów cysterskich na Śląsku w średniowieczu'.

W przeprowadzonych do tej pory badaniach nad pieczęciami cysterskimi, w tym śląskimi, przeanalizowano w znacznej mierze pieczęcie w zakresie ich ikonografii z okresu średniowiecza, mniej miejsca poświęcono pieczęciom z okresu nowożytnego. Refleksją objęto również zagadnienia związane z heraldyką wybranych klasztorów. Często opierano się jednak na fragmentarycznej podstawie źródłowej, co prowadziło do częściowego jedynie rozpoznania pieczęci stosowanych $\mathrm{w}$ danym opactwie oraz ich ikonografii, a także funkcjonujących w danej wspólnocie herbów?

Podstawę rozważań w niniejszym tekście stanowią źródła zachowane w przeważającej liczbie w Archiwum Państwowym we Wrocławiu [dalej: AP Wrocław], Archiwum Archidiecezjalnym we Wrocławiu [dalej: AA Wrocław] oraz Muzeum Narodowym we Wrocławiu [dalej: MN Wrocław]. Istotne z punktu widzenia niniejszych badań są także pojedyncze pieczęcie z zasobu Geheimes Staatsarchiv Preussisches Kulturbesitz w Berlinie [dalej: GStA PK], Národního archivu w Pradze oraz Archiwum Państwowego we Wrocławiu Oddziału w Legnicy. W wyniku przeprowadzonych badań zebrałem informacje o 61 typach pieczęci stosowanych przez opatów od schyłku średniowiecza do $1810 \mathrm{r}$. Z tej liczby tylko 9 pieczęci zostało opublikowanych w postaci zdjęć i opisów we wcześniejszej literaturze przedmiotu

\section{Opat wobec wspólnoty klasztornej}

Opat przewodzący wspólnocie zakonnej w klasztorach cysterskich dysponował władzą duchową i świecką. Jego pozycja ulegała zmianom na przestrzeni czasu, co jest szczególnie widoczne w późnym średniowieczu. Urząd opata stał się wówczas bardziej wyodrębniony ze wspólnoty mnichów. Na taką

\footnotetext{
2 Na istotną rolę badania ustawodawstwa zakonnego w kontekście pieczęci zwróciła ostatnio uwagę B.M. Bedos-Rezak, When Ego Was Imago. Signs of Identity in the Middle Ages, Leiden-Boston 2011, s. 250, przyp. 60.

${ }_{3}$ T.A. Heslop, Cistercian Seals in England and Wales, w: Cistercian Art and Architecture in the British Isles, red. Ch. Norton, D. Park, Cambridge 1986, s. 282; P. Stróżyk, Pieczęcie cysterskie z opactwa w Leknie-Wagrowcu (cz. II), „Studia i Materiały do Dziejów Pałuk”, 6, 2006, s. 145-148; T. Kałuski, Imago abbatis na pieczęciach ślaskich cystersów w średniowieczu, w: Dzieje i kultura cystersów w Polsce 2, red. M. Starzyński, D. Tabor, Kraków 2018, s. 397-398, 402-403.

${ }^{4}$ Statuta capitulorum generalium ordinis cisterciensis ab anno 1116 ad annum 1786, t. 7: Ab anno 1546 ad annum 1786, wyd. J.-M. Canivez, Louvain 1939: 1567/11, 1601/cap. XI/12, 1601/cap. XXVI/9, 1601/Cap. XXXIV/2, 1605/63; Constitutio Alexandri Papae VII pro Generali Ordinis Cisterciensis Reformatione, w: tamże, s. 427, pkt 2, s. 432, pkt 27, $1738 / 69$.

5 AP Wrocław, Rep. 83, nr 903; zob. też H. Grüger, Heinrichau. Geschichte eines schlesischen Zisterzienserklosters 1227-1977, Köln 1978, s. 189.

${ }_{6}^{6}$ T. Kałuski, Imago abbatis, s. 395-415, 665-667.

${ }^{7}$ Zob. zestawienie podstawowej literatury: M. Szymoniak, Średniowieczne pieczęcie cysterskie z diecezji krakowskiej jako źródto badań nad zakresem władzy opatów i konwentów, „Zeszyty Naukowe Towarzystwa Doktorantów Uniwersytetu Jagiellońskiego. Nauki Społeczne”, 9, 2014, nr 2, s. 147-148; T. Kałuski, Imago abbatis, s. 396; A. Bojęś-Białasik, M. Zdanek, Badania nad cystersami w Polsce po 1989 r., w: Dzieje i kultura cystersów w Polsce 2, s. 545-546.

${ }^{8}$ Pełne zestawienie pieczęci z podanym miejscem ich przechowywania zob. Inwentarz pieczęci opatów lubiąskich (XV/XVI$-X I X$ w.) zamieszczony w drugiej części pracy [dalej: Inwentarz].
} 
sytuację wpłynęły zarówno czynniki zewnętrzne, jak np. kontakty z władzą świecką, które wymagały częstej nieobecności w klasztorze, ale także zmiany zachodzące w łonie wspólnot cysterskich i samego zakonu. Wyższe wykształcenie umożliwiało szybsze uzyskanie urzędu opata i podejmowanie różnych działań na rzecz klasztoru w celu obrony jego praw oraz życia monastycznego. Niektórzy z opatów zostali też włączeni w misje reformatorskie na rzecz innych klasztorów. Emilia Jamroziak zwróciła uwagę, że skutkiem zmiany charakteru urzędu opackiego był fakt, że na poziomie reprezentacji zbliżyli się oni do innych dostojników kościelnych, szczególnie biskupów. Opaci podkreślali swoją pozycję poprzez działalność fundacyjną, oddzielne rezydencje, zasiadanie na tronie, używanie pontyfikaliów, ale także, co jest szczególnie istotne, posiadanie własnych pieczęci i herbów9.

W klasztorze lubiąskim zmiana pozycji opata zachodziła w podobny sposób, szczególnie od późnego średniowiecza ${ }^{10}$, i była manifestowana również na porównywalnych płaszczyznach. Niektórzy opaci podejmowali aktywność fundatorską. W jej ramach odbudowano klasztor, w tym wzniesiono dom opata, wyposażono kościół klasztorny, część z nich była też darczyńcami książek do biblioteki klasztornej ${ }^{11}$. Opaci w Lubiążu pozyskali także u schyłku średniowiecza pontyfikalia. Stosowali też herb odnoszący się do ich urzędu, podkreślając jego odrębność. Herb klasztoru pozostający w ich gestii wskazywał nie tylko na opactwo, ale i na przełożonego klasztoru, który działał w jego imieniu. Zwiększyła się również z czasem liczba pieczęci stosowanych przez opatów, a zatem i możliwości wykorzystania ich potencjału wizualnego. W dalszej części pracy dowodzę, że pieczęcie były jednymi z głównych mediów wykorzystywanych przez opatów do eksponowania ich odrębnej pozycji we wspólnocie klasztornej.

Wszechstronna aktywność opatów wewnątrz klasztoru oraz w kontaktach ze światem, będąca podstawą ich wysokiej pozycji, nie byłaby jednakże możliwa bez wsparcia kancelarii klasztornej i innych urzędów. Stąd w dokumentach nowożytnych wystawianych samodzielnie przez opatów, lub których opat był współwystawcą, wymieniane są osoby świeckie, np. kanclerz, sekretarz czy też urzędnicy bez doprecyzowania rangi, a także zakonnicy pełniący urzędy administratora, prowizora, proboszcza w parafii czy prepozyta (np. w Kazimierzu, Sicinach czy Słupie). Wspierali oni bowiem lub zastępowali opata $\mathrm{w}$ niektórych czynnościach prawnych ${ }^{12}$. Przy części dokumentów współwystawcą byli np. prepozyci ${ }^{13}$.

\section{Elekcja opata a pieczęcie}

Do schyłku średniowiecza mamy jedynie ogólne informacje o przebiegu elekcji opatów lubiąskich ${ }^{14}$. Z czasów późniejszych zachowały się już dokumenty potwierdzające elekcję oraz opis towarzyszącego

\footnotetext{
${ }^{9}$ E. Jamroziak, The Cistercian Order in Medieval Europe 1090-1500, Abingdon 2013, s. 263-265; taż, Cistercian Abbots in Late Medieval Central Europe. Between the Cloister and the World, w: The Prelate in England and Europe 1300-1560, red. M. Heale, Woodbridge 2014, s. 240-257.

${ }_{10}$ W.P. Könighaus, Die Zisterzienserabtei Leubus in Schlesien von ihrer Gründung bis zum Ende des 15. Jahrhunderts, Wiesbaden 2004, s. 77-96.

${ }^{11}$ Uwypuklono to w piśmiennictwie klasztornym: Martin Sebastian Dittmans Chronik der Aebte von Leubus, wyd. W. Wattenbach, „Zeitschrift des Vereins für Geschichte und Alterthum Schlesiens”, 1, 1856, s. 282-297; Monumenta Lubensia, wyd. W. Wattenbach, Breslau 1861, s. 45-46, 49, 52-53, 58. W przypadku opata Tobiasza Stusche oprócz wzmianki o jego nagłej śmierci wskazano jedynie na jego zażyłe stosunki z królem pruskim Fryderykiem II (familiaris Regi Borussorum); zob. Monumenta Lubensia, s. 42.

12 Szczególnie jest to widoczne w dokumentach dotyczących rozgraniczenia wsi klasztornych od świeckich; zob. np. AP Wrocław, Rep. 91, nr 1091, 1093, 1094, 1111, 1121, 1122, 1142, 1143, 1152, 1169, 1216, 1221, 1227, 1291, 1296. Interesujący jest zwłaszcza dokument z 1608 r. wystawiony przez opata Mateusza Rudolfa, w którym udzielił on upoważnienia urzędnikowi klasztornemu Johannowi Kunradtowi oraz kanclerzowi klasztornemu Lorentzowi Arnoldenowi do zbadania granicy w Sichowie; zob. tamże, nr $782 \mathrm{~b}$.

13 Przykładowo: tamże, nr 1126, 1223, 1224, 1225, 1231, 1234.

${ }^{14}$ Martin Sebastian Dittmans Chronik, s. 280-282; Monumenta Lubensia, s. 22; Aus dem ältesten Signaturbuche des Klosters Leubus, wyd. H. Grotefend, „Zeitschrift des Vereins für Geschichte und Alterthum Schlesiens”, 12, 1874, nr 1, s. $202-207$.
} 
jej obrzędu, zawarty w pontyfikale spisanym w $1555 \mathrm{r} \cdot{ }^{15} \mathrm{Na}$ podstawie tych źródeł wiadomo, że opata w Lubiążu wybierali przez głosowanie członkowie konwentu pod przewodnictwem - do pierwszej połowy XVI w. - opatów śląskich jako delegatów opata z Pforty, przy wsparciu asesorów. W drugiej połowie tego stulecia procedurze elekcji przewodzili opaci filiacji lubiąskiej (Henryków i Kamieniec), a od drugiej połowy XVII w. wikariusze generalni lub przełożeni klasztorów filialnych ${ }^{16}$. Jednym z istotnych elementów następujących po elekcji była instalacja opata, a także potwierdzenie jego wyboru przez obecnych opatów. W dokumencie z poświadczenia wyboru Andrzeja Hoffmanna na opata w 1498 r., wystawionym przez opata z Krzeszowa Jana i opata z Kamieńca Jakuba, umieszczono również zapis o wprowadzeniu elekta $\mathrm{w}$ rządy nad opactwem poprzez przekazanie mu pieczęci ${ }^{17}$. Tego typu zapisy znane są również z XVI- i XVII-wiecznych dokumentów elekcyjnych ${ }^{18}$. Na podstawie tych oraz innych dokumentów elekcyjnych z tego i następnego stulecia, znanych tylko z regestów archiwalnych, a także praktyki związanej ze stosowaniem poszczególnych pieczęci przez opata wiadomo, że nowo wybrany opat był wprowadzany w posiadanie opactwa poprzez przekazanie pieczęci większej swojego poprzednika oraz kluczy ${ }^{19}$. We wspomnianym pontyfikale z połowy XVI w. wymieniono Regułę św. Benedykta, którą otrzymywał opat elekt na znak pieczy nad sprawami duchowymi, a także wręczano mu pieczęć, powierzając rządy doczesne (curam temporalium) ${ }^{20}$. W dokumentach z potwierdzenia elekcji z 1696, 1729 i 1733 r. zawarto informacje o przekazaniu Reguły św. Benedykta, pieczęci (nie doprecyzowano, że chodzi o większą) oraz kluczy ${ }^{21}$. Należy zaznaczyć, że w wolne kanoniczne wybory opatów lubiąskich ingerowały zarówno władze kościelne (biskup wrocławski ${ }^{22}$ ), jak i świeckie (Piastowie z linii legnicko-brzeskiejej, a następnie Habsburgowie ${ }^{24}$ ).

W okresie rządów Hohenzollernów na Śląsku sposób wyboru opatów zmienił się radykalnie. Odtąd konwent dokonywał, w obecności komisarza królewskiego, wyboru trzech kandydatów, których przedstawiał królowi pruskiemu celem nominacji i zatwierdzenia jednego z nich ${ }^{25}$. Następnie władca

15 Biblioteka Uniwersytecka we Wrocławiu [dalej: BUWr.], Oddział Rękopisów [dalej: OR], sygn. I F 382, k. 50r-59r; zob. też F. Wolnik, Liturgia śląskich cystersów w średniowieczu, Opole 2002, s. 100, 469-473. Należy zauważyć, że badacz nieprecyzyjnie opisał przebieg elekcji oraz obrzęd benedykcji po wyborze nowego opata.

${ }^{16} \mathrm{Na}$ przykład w 1584 r. opat z Henrykowa Mikołaj wystawił dokument, w którym potwierdził elekcję opata Hieronima, a w roli współpieczętujących wystąpili opat z Kamieńca jako asesor oraz konwent lubiąski; zob. AP Wrocław, Rep. 91, $\mathrm{nr}$ 755. W połowie XVII w. sytuacja uległa zmianie. Elekcjom opata przewodniczył wikariusz śląski, co zaznaczono już w dokumencie nominacyjnym opata lubiąskiego Arnolda Freibergera z 1649 r. W uchwale z 1733 r. usankcjonowano praktykę dotyczącą przewodniczenia elekcji w klasztorach dolno- i górnośląskich oraz w Lubiążu na wypadek śmierci opata W momencie pełnienia przez niego urzędu wikariusza generalnego; zob. AA Wrocław, sygn. VB4a, bpag.; BUWr., OR, sygn. IV F 209, s. 83-85; AP Wrocław, Rep. 83, nr 903, s. 2-4. Należy wskazać jednakże, że elekcji z 1729 r. przewodniczyli opaci dolnośląscy, a nie wikariusz generalny, którym był mianowany w tym samym roku przez opata generalnego opat z Jemielnicy; zob. AP Wrocław, Rep. 85, nr 244. Zapewne było to wywołane niechęcią wobec niskiego statusu klasztoru górnośląskiego; zob. H. Grüger, Der Orden der Zisterzienser in Schlesien (1175-1810), „Jahrbuch der Schlesischen Friedrich-Wilhelms-Universität zu Breslau”, 23, 1982, s. 132.

${ }^{17}$ AP Wrocław, Rep. 91, nr 634.

18 Tamże, nr 690, 755, 763; AP Wrocław, Rep. 83, nr 701a.

19 AP Wrocław, Rep. 91, nr 739, 853, 929.

${ }^{20}$ BUWr., OR, sygn. I F 382.

${ }^{21}$ AP Wrocław, Rep. 91, nr 1009a (kopia: AA Wrocław, sygn. V26, bpag.), 1174; Rep. 83, nr 882. W obu ostatnich dokumentach potwierdzających elekcję dodano ponadto klauzule informujące o zawieszeniu administrowania w sprawach doczesnych do momentu cesarskiego zatwierdzenia.

${ }^{22}$ H. Nentwig, Zum Exemtionsstreite zwischen den Bischöfen von Breslau und den Zisterzienseräbten in Schlesien, w: Studien zur schlesischen Kirchengeschichte, Darstellungen und Quellen zur schlesischen Geschichte, t. 3, Breslau 1907, s. 111-136; H. Grüger, Heinrichau, s. 173-178; K.K. Jażdżewski, Lubiąz. Losy i kultura umysłowa śląskiego opactwa cystersów (1163-1642), Wrocław 1993, s. 78-79; Katalog duchowieństwa diecezjalnego i zakonnego na podstawie księgi święceń biskupów wrocławskich 1650-1810/12, oprac. S. Jujeczka, H. Gerlic, W. Könighaus, Wrocław 2014, s. 65-67.

${ }^{23}$ AP Wrocław, Rep. 91, nr 688; K. Wutke, Der Streit um Leubus zwischen König und Herzog 1534-1565, ,Zeitschrift des Vereins für Geschichte und Alterthum Schlesiens”, 33, 1899, s. 135-136; K.K. Jażdżewski, Lubiąż, s. 76; W.P. Könighaus, Die Zisterzienserabtei Leubus, s. 132-133.

${ }^{24}$ H. Nentwig, Zum Exemtionsstreite, s. 121; H. Grüger, Schlesisches Klosterbuch. Leubus, „Jahrbuch der Schlesischen Friedrich-Wilhelms-Universität zu Breslau”, 22, 1981, s. 7-8; tenże, Der Orden der Zisterzienser in Schlesien, s. 102.

${ }^{25}$ AP Wrocław, Rep. 83, nr 1040. 
wystawiał dokument, w którym nominował i potwierdzał wybranego przez siebie opata, począwszy od elekcji w 1747 r. Elekt składał przysięgę homagialną również królowi ${ }^{26}$. Opaci wprowadzali zatwierdzonego opata w rządy nad opactwem. Nadal podczas tej ceremonii wręczano Regułę św. Benedykta jako niezbędną do sprawowania rządów duchowych oraz pieczęć opacką (nie precyzując nadal, że chodzi o większą) do rządów doczesnych ${ }^{27}$. Nowi opaci byli również potwierdzani przez opata generalnego ${ }^{28}$.

Wybrany opat, ze względu na krótki czas między elekcją a instalacją, otrzymywał pieczęć po swoim poprzedniku. Dotyczyło to z pewnością pieczęci większej, a nie jego pieczęci mniejszych. Według wzmiankowanej już uchwały opata generalnego Andochiusza Pernota z 1733 r. pieczęcie po zmarłym opacie miał otrzymać wikariusz generalny albo w razie jego choroby lub innej przeszkody opat ojciec. W przypadku opata lubiąskiego, który mógł pełnić urząd wikariusza, zaznaczono, że po jego śmierci pieczęcie miały trafić do najstarszego opata z klasztoru w Henrykowie, Kamieńcu lub Krzeszowie. Jeśli opat senior zachorował lub zaszła inna przeszkoda pieczęcie oraz przewodzenie nowej elekcji miały zostać przekazane kolejnemu opatowi (,ad alterum duorum abbatum seniorem”) ${ }^{29}$.

Wymienione podczas przekazania władzy opatowi pieczęć oraz klucze Paweł Stróżyk zaliczył do insygniów opackich ${ }^{30}$. Zgadzając się z tą opinią, należy podkreślić, że pieczęć jako jeden z niezbędnych przedmiotów w sprawowaniu władzy była szczególnie predestynowana do kreowania pożądanego przez opata obrazu jego osoby. Wykonywane przy pomocy typariusza liczne odciski tej samej pieczęci pozwalało nie tylko na utrwalenie przedstawienia napieczętnego, ale też na dotarcie do różnych grup odbiorców.

\section{Wizerunki na pieczęciach opata Andrzeja Hoffmanna na przelomie XV i XVI w.}

Przełom średniowiecza i czasów nowożytnych w dziejach klasztoru lubiąskiego to czas rządów Andrzeja Hoffmanna (1498-1534). Prowadził on wzmożoną aktywność w celu ochrony przywilejów klasztornych, restytuował utracone majątki klasztorne oraz czynsze, a także prowadził inwestycje we wsiach klasztornych ${ }^{31}$. Z okresu jego rządów znana jest pieczęć większa, potwierdzona w użyciu w latach 1498-153232. Część jego dokumentów została wystawiona wspólnie z konwentem lubiąskim, choć nie wszystkie zostały opieczętowane pieczęcią konwentu ${ }^{33}$. Niezwykle interesujące są określenia pieczęci użyte $\mathrm{w}$ formułach sigillacyjnych. W dokumencie z 1506 r. określono ją mianem pieczęci opactwa (eptey eyngesigel) ${ }^{34}$, a w dokumencie z 1525 r. pieczęć opata Andrzeja nazwano większą ${ }^{35}$. Jest to pieczęć ostroowalna o wymiarach 69 x $45 \mathrm{~mm}$, przywieszona przy dokumentach na paskach pergaminowych oraz w jednym przypadku na jasnym sznurze. Odciskano ją najczęściej w wosku czerwonym $\mathrm{w}$ miskach $\mathrm{z}$ wosku naturalnego. Dwa razy potwierdzone jest użycie wosku zielonego. W polu pieczęci widoczna jest postać św. Bernarda z Clairvaux jako mnicha, opata oraz świętego. Wyobrażono go przy pomocy charakterystycznych atrybutów, znanych z innych przekazów ikonograficznych z okresu

${ }^{26}$ GStA PK, I. HA Rep. 46 B Schlesien seit 1740, nr 168f, bpag.; AP Wrocław, Rep. 91, nr 1269; zob. też B. Braun, Friedrich der Große und seine Politik gegenüber der katholischen Kirche in Schlesien, „Zeitschrift der Savigny-Stiftung für Rechtsgeschichte. Kanonistische Abteilung”, 78, 1992, s. 241. Procedurę wyboru opata w Lubiążu przez króla w 1757 r. przedstawił K. Wutke, Die Leubuser Abtswahl von 1757, „Zeitschrift des Vereins für Geschichte und Alterthum Schlesiens”, 24, 1890, s. 374-376. Należy podkreślić, że decyzję o wyborze opata król pruski podejmował przy uwzględnieniu rady ministra ds. Śląska.

27 AA Wrocław, Dokumenty klasztoru w Henrykowie, nr 274 (7 III 1769); tamże, Rep. 83, nr 1150, 1157.

28 Tamże, Rep. 91, nr 1270, 1295.

${ }^{29}$ Tamże, Rep. 83, nr 903, s. 3-4.

${ }^{30}$ P. Stróżyk, Symbole władzy opata w przestrzeni klasztoru cysterskiego, w: Ingenio et humilitate. Studia z dziejów zakonu cystersów i Kościoła na ziemiach polskich, red. A.M. Wyrwa, Katowice 2007, s. 45.

${ }_{31}$ Martin Sebastian Dittmans Chronik, s. 282-284; W.P. Könighaus, Die Zisterzienserabtei Leubus, s. 89.

32 Zob. Inwentarz, nr 1.

33 AP Wrocław, Rep. 91, nr 598, 633, 661, 681, 682; AP Wrocław, Oddział Legnica, Dokumenty miasta Legnicy, sygn. 647.

${ }^{34}$ AP Wrocław, Rep. 91, nr 598.

35 Tamże, nr 661. 
średniowiecza ${ }^{36}$. Ukazano go bowiem w kukulli, z nałożonym na ramiona mucetem $\mathrm{z}$ kapturem, z nimbem wokół głowy, na której zaznaczono tonsurę ${ }^{37}$. W prawej ręce trzyma pastorał o krzywaśni zwróconej na zewnątrz, z motywem kwiatonu w wolucie, a lewą przytrzymuje księgę, identyfikowaną przez badaczy jako Reguła św. Benedykta. Pod wspornikiem umieszczono głowę św. Jana Chrzciciela na misie. Święty stoi na wsporniku w gotyckiej edykule baldachimowej. Wizerunek tej pieczęci oraz legenda jest bardzo zbliżona do pieczęci używanych przez poprzedników opata Andrzeja od pierwszej połowy XV w. Można zatem wysunąć wniosek, że kolejni opaci w XV w., łącznie z Andrzejem, posługiwali się tym samym tłokiem ${ }^{38}$. Wprowadzenie na pieczęć św. Bernarda było zapewne formą wskazania wzoru do naśladowania dla każdego $\mathrm{z}$ opatów ${ }^{39}$. Innym czynnikiem mogło być dążenie do pozyskania opieki tego świętego nad klasztorem i jego dobrami, co było szczególnie ważne w okresie zniszczeń opactwa i jego majątków dokonanych przez husytów w pierwszej połowie XV w. oraz w okresie walk Władysława i Kazimierza Jagiellończyków z Maciejem Korwinem w drugiej połowie stulecia ${ }^{40}$. Na pieczęci opata Andrzeja dokonano także niewielkich zmian w legendzie. Przerytowano tylko imię poprzednika Bartłomieja II Lehnmana oraz wprowadzono w miejsce obok wici roślinne. Interesujące jest pierwsze poświadczone użycie omawianej pieczęci większej. Została ona mianowicie przywieszona przy dokumencie wystawionym 26 IV 1498, który dotyczył rezygnacji z urzędu poprzedniego opata Bartłomieja II Lehnmana ${ }^{41}$. Opat Andrzej został wybrany w tym samym dniu ${ }^{42}$. Wybór potwierdził Jan opat z Krzeszowa w zastępstwie opata z Pforty, wraz z asesorem Jakubem opatem z Kamieńca, w obecności konwentu. Tego samego dnia sporządzono również stosowny dokument. Wystawieniu obu dokumentów towarzyszyło opieczętowanie, które nastąpiło zapewne niedługo po 26 kwietnia. Możemy zatem przyjąć, że tłok opata elekta także został przerytowany w tym czasie, zapewne na miejscu w klasztorze.

Opat Andrzej posługiwał się w praktyce kancelaryjnej również pieczęcią mniejszą pieszą, która została odnotowana w użyciu w $1521 \mathrm{r}$. W dokumencie określono ją jako sekretną. Jest to pieczęć okrągła o średnicy $26 \mathrm{~mm}$, która została przywieszona na pasku pergaminowym. Odciśnięto ją w wosku czerwonym, $\mathrm{w}$ misce $\mathrm{z}$ wosku naturalnego ${ }^{43}$. Wizerunek napieczętny uległ zasadniczej zmianie. W polu pieczęci został bowiem wyobrażony już nie święty, ale opat w kukulli z nałożonym na ramiona mucetem z kapturem. Wypada zauważyć, że strój ten w owym czasie był w użyciu nie tylko w liturgii, ale także w życiu codziennym ${ }^{44}$. W prawej ręce opat trzyma pastorał jako symbol najwyższej władzy duchowej wobec

36 J. France, Medieval Images of Saint Bernard of Clairvaux, Kalamazoo, Mich. 2007, s. 21-48, 81-89; M. Kawa, Święty Bernard z Clairvaux - najbardziej rozpowszechnione typy ikonograficzne, w: Dzieje i kultura cystersów w Polsce 1, red. M. Starzyński, D. Tabor, Kraków 2016, s. 87-96.

${ }^{37} \mathrm{Na}$ temat habitu, w tym cysterskiego, zob. G. Zimmermann, Ordensleben und Lebensstandard. Die Cura Corporis in den Ordensvorschriften des abendländischen Hochmittelalters, Beiträge zur Geschichte des Alten Mönchtums und des Benediktinerordens, t 32, Münster 1971, s. 88-109, 341-403; P.P. Gach, Habity zakonne w średniowieczu. Zarys problematyki, w: Klasztor w kulturze średniowiecznej Polski, red. A. Pobóg-Lenartowicz, M. Derwich, Opole 1995, s. 491-516; M. Derwich, Habit - zarys problematyki, w: Scriptura, diploma, sigillum. Prace ofiarowane Profesorowi Kazimierzowi Bobowskiemu, red. J. Zdrenka, J. Karczewska, Zielona Góra 2009, s. 45-49. Na szczególną uwagę zasługują prace omawiające wyłącznie habit cysterski: J. France, The Cistercians in Medieval Art, Stroud 1998; S. Slawik, Die Kleidung der Cistercienser im Mittelalter. Weiße Mönche im braunen Kleid, „Analecta Cisterciensia”, 65, 2015, s. 134-151; A.M. Wyrwa, O stroju zakonnym cystersów w świetle wybranych źródeł normatywnych i tradycji zakonnej. Zarys problemu, w: Klio viae et invia. Opuscula Marco Cetwiński dedicata, red. A. Odrzywolska-Kidawa, Warszawa 2010, s. 547-564 (w cytowanych pracach dalsza literatura przedmiotu).

38 T. Kałuski, Imago abbatis, s. 413.

39 E. Jamroziak, Cistercian Abbots, s. 253-254.

${ }^{40}$ W.P. Könighaus, Die Zisterzienserabtei Leubus, s. 77-90. Warto wskazać, że autor przedstawił przy tym argumenty, które nie poświadczają rozluźnienia dyscypliny w konwencie lubiąskim w XV w. w takim stopniu jak prezentowała to starsza literatura; zob. H. Grüger, Monastische Disziplin der schlesischen Zisterzienser vor Anbruch der Reformation, „Cîteaux”, 24, 1973, s. 209-249; tenże, Schlesisches Klosterbuch. Leubus, s. 6; K.K. Jażdżewski, Lubiąż, s. 69.

${ }^{41}$ AP Wrocław, Rep. 91, nr 571.

42 Tamże, nr 634. W.P. Könighaus (tenże, Die Zisterzienserabtei Leubus, s. 374) datuje dokument na 27 kwietnia, czego nie potwierdza ponowny odczyt dnia.

${ }^{43}$ Inwentarz, nr 2.

${ }^{44}$ S. Slawik, Die Kleidung der Cistercienser, s. 139. 
mnichów, a lewą przytrzymuje Regułę, którą, jak już wspomniałem, otrzymywał uroczyście po wyborze. Na głowie opata została po raz pierwszy wyobrażona infuła. Całość dopełnia legenda : S(igillum) • ANDRE $(a)$ E $/ \bullet:$ ABBBATIS :, wykonana kapitałą. Wskazuje ona na dysponenta pieczęci i jego urząd.

Pojawienie się infuły na pieczęci sekretnej należy wiązać z otrzymaniem w 1498 r. przez opata bulli pontyfikalnej z rąk papieża Aleksandra $\mathrm{VI}^{45}$. Nadano w niej opatowi Andrzejowi i jego następcom, poza posiadanym już pastorałem, prawo używania mitry, pierścienia oraz innych oznak pontyfikalnych („,mitra et annulo ac aliis pontificalibus insigniis”) ${ }^{46}$. Dla uzyskania tego przywileju Andrzej Hoffmann dokonał odpowiedniej opłaty za wydanie bulli, a następnie zamówił jako pierwszą z pontyfikaliów kosztowną infułę w typie pretiosa oraz opłacił jej pobłogosławienie wraz z pastorałem przez biskupa wrocławskiego ${ }^{47}$. Posiadając pontyfikalia, używał ich podczas celebrowania uroczystej mszy świętej ${ }^{48}$. Mogły być wykorzystywane, jak pokazują przykłady z różnych klasztorów, również podczas innych okazji, jak uroczystości pogrzebowe czy przyjmowania ważnych gości. Umożliwiało to podkreślenie jego wysokiego statusu także wobec odbiorców spoza klasztoru ${ }^{49}$. Opaci lubiąscy na mocy omawianej bulli z 1498 r. otrzymali też dalsze uprawnienia przynależne biskupowi, co w jeszcze większym stopniu podkreślało ich wysoką pozycję w opactwie. Mogli bowiem błogosławić paramenty liturgiczne niezbędne do sprawowania kultu bożego, a także uzyskali prawo udzielania tonsury nowicjuszom i mnichom $\mathrm{w}$ klasztorze ${ }^{50}$. Pomimo kłopotów finansowych klasztorów śląskich, w tym lubiąskiego ${ }^{51}$, pozyskanie pontyfikaliów umocniło pozycję opata lubiąskiego oraz klasztoru ${ }^{52}$, zwłaszcza że wśród cysterskich klasztorów na ziemiach polskich Lubiąż był jednym z pierwszych obdarowanych tym przywilejem ${ }^{53}$. Ich eksponowanie na pieczęci mniejszej umożliwiało utrwalenie pożądanego wizerunku u szerszego grona odbiorców.

Opat Andrzej zamanifestował także swoją odrębną pozycję we wspólnocie oraz na zewnątrz, prowadząc działalność fundacyjną na szeroką skalę. Odbudował kościół klasztorny, wzniósł nowy dom

${ }^{45}$ AP Wrocław, Rep. 91, nr 573. Na temat pontyfikaliów używanych przez opatów zob. P. Szczaniecki, „Pontyfikalia” tynieckich opatów w średniowieczu, w: Cultus et cognitio. Studia z dziejów średniowiecznej kultury, Warszawa 1976, s. 557-563; M. Derwich, Rola opata w koronacjach królów polskich, w: Imagines potestatis. Rytualy, symbole, i konteksty fabularne władzy zwierzchniej. Polska X-XV w. (z przyktadem czeskim i ruskim), red. J. Banaszkiewicz, Warszawa 1994, s. 31-58; M. Gronowski, Insygnia władzy opackiej i ich symbolika, w: Imago narrat. Obraz jako komunikat w społeczeństwach europejskich, red. S. Rosik, P. Wiszewski, Wrocław 2002, s. 351-357; M. Stawski, „Abbas in pontificalibus”- wokót praw i przywilejów pontyfikalnych opatów $w$ średniowieczu $w$ świetle bulli dla klasztorów polskich z XIV $i$ XV $w$., w: Klio viae et invia, s. 609-617. Pontyfikalia są niekiedy określane mianem „insygniów”. Stosuje się ten termin niewłaściwie także na elementy szat będące oznaką godności, jak np. infułę.

${ }^{46}$ AP Wrocław, Rep. 91, nr 573.

47 Tamże, Rep. 135, nr D 219, s. 32; H. Grüger, Monastische Disziplin, s. 232.

$48 \mathrm{~W}$ pontyfikale lubiąskim z 1555 r. opisano m.in. czynności podejmowane przez opata podczas celebrowania mszy pontyfikalnej; zob. BUWr., OR, sygn. I F 382; zob. też F. Wolnik, Liturgia śląskich cystersów, s. 292-316.

${ }^{49}$ M. Heale, Mitres and Arms. Aspects of the Self-Representation of the Monastic Superior in Late Medieval England, w: Self-Representation of Medieval Religious Communities. The British Isles in Context, red. A. Müller, K. Stöber, Berlin 2009 , s. 106.

${ }^{50}$ AP Wrocław, Rep. 91, nr 573; zob. też M. Stawski, „Abbas in pontificalibus”, s. 616-617. Autor mimo wymowy bulli wskazał, że opaci poza udzielaniem tonsury mogli też udzielać niższych święceń.

${ }^{51}$ Statuta capitulorum generalium ordinis cisterciensis ab anno 1116 ad annum 1786, t. 6: Ab anno 1491 ad annum 1542, wyd. J.-M. Canivez, Louvain 1938, 1502/17. Kapituła generalna ze względu na ubóstwo klasztorów na Śląsku zwolniła je w 1502 r. z wysyłania przez 3 lata mnichów na studia.

${ }^{52}$ Taki pogląd wyraził W.P. Könighaus, Die Zisterzienserabtei Leubus, s. 89-90. Natomiast E. Jamroziak (taż, The Cistercian Order, s. 264) interpretuje pozyskanie pontyfikaliów w obliczu złej kondycji finansowej jako wyraz osobistych ambicji opata, stojących w sprzeczności z dobrem wspólnoty.

${ }^{53}$ Dane na temat chronologii wprowadzania pontyfikaliów w klasztorach cysterskich na ziemiach polskich zebrał P. Stróżyk, Symbole władzy opata, s. 49-50. Pierwsze pewne informacje na temat uzyskania pontyfikaliów pochodzą z $1415 \mathrm{r}$. z Mogiły. Z klasztorów cysterskich z terenów zachodniej Europy znane są tego typu przywileje od drugiej połowy XIII w.; D.H. Williams, The Cistercians in the Early Middle Ages, Leominster 1998, s. 73; M. Stawski, Benedykcja opata cysterskiego w średniowieczu, w: Pelplin. 725. rocznica powstania opactwa cysterskiego. Kulturotwórcza rola cystersów na Kociewiu, red. D.A. Dekański, B.A. Grenz, A. Słyszewska, A.M. Wyrwa, Pelplin-Tczew 2002, s. 380. Część badaczy wskazuje natomiast pierwszą połowę XIV w.; zob. L.J. Lekai, The Cistercians. Ideals and Reality, Kent, OH, 1977, s. 256; J. France, The Cistercians, s. 116-118. 
opata, zamówił relikwiarze, obrazy, szaty oraz paramenty liturgiczne, a także elementy wyposażenia kościoła $^{54}$. Jego pozycja została podkreślona również poza klasztorem. Na tympanonie pochodzącym z niezachowanej kurii opatów w Legnicy wyeksponowano mianowicie pastorał oraz infułę podtrzymywaną przez dwa uskrzydlone anioły $\mathrm{z}$ wyrytą poniżej datą: $1522^{55}$.

\section{Zmiana i kontynuacja na pieczęciach następców opata Andrzeja Hoffmanna w XVI w.}

Z okresu rządu opata Jana V Franco (1534-1539) zachowały się jego pieczęć większa oraz mniejsza piesza. Pieczęć główna znana jest z egzemplarza z 1536 r., ale dowodnie była używana do końca rządów tego opata ${ }^{56}$. Zachowana pieczęć ma formę ostroowalną o wymiarach 67 x $43 \mathrm{~mm}$. Została odciśnięta $\mathrm{w}$ wosku czerwonym w misce $\mathrm{z}$ wosku naturalnego. Przywieszono ją przy dokumencie na pasku pergaminowym. Dokument był współpieczętowany przez konwent. Wyobrażenie napieczętne zerwało z tradycją ikonograficzną sięgającą pierwszej połowy XV w. W polu pieczęci przedstawiono bowiem opata $\mathrm{w}$ kukulli $\mathrm{z}$ nałożonym na ramiona mucetem $\mathrm{z}$ kapturem oraz infułą $\mathrm{w}$ typie pretiosa na głowie. Postać stoi na tle renesansowej edykuły o wysuniętych profilowanych cokołach, które podtrzymują dwukondygnacyjne pilastry o profilowanych płycinach i wydatnych gzymsowaniach. Na linii górnych gzymsowań zaznaczono ponadto perspektywicznie gzyms półkolistej wnęki zwieńczonej konchą. Po bokach edykuły widać wysunięte cokoły z ustawionymi na nich wazami z zatkniętymi kwiatami na długich łodygach ${ }^{57}$. Opat w prawej ręce trzyma pastorał, a w lewej księgę, którą należy, jak wskazałem wcześniej, utożsamiać z Regułą. Poniżej edykuły umieszczono herb urzędowy opata (na tarczy szachowany dwurzędowy skos skrzyżowany z pastorałem, na nich głowa św. Jana Chrzciciela na misie $)^{58}$. Wprowadzenie na pieczęć większą infuły podkreślało dobitnie szczególną pozycję opata w klasztorze. Takie same zadanie spełniał herb. Od tej pory znak ten zagościł na pieczęciach opatów lubiąskich, pozostając w użyciu z przerwami aż do schyłku XVIII w. Pieczęć opata Jana V wyróżnia się pod jeszcze jednym względem. Po raz pierwszy bowiem w sfragistyce opatów lubiąskich zawarty został element chronologiczny. Na cokołach wyryto rozdzieloną na dwie części datę: 15/35. Wskazuje ona, że opat Jan posługiwał się od momentu wyboru we wrześniu 1534 r. przez kilka miesięcy pieczęcią po zmarłym opacie Andrzeju. Wizerunek napieczętny dopełnia wykonana kapitałą inskrypcja umieszczona w otoku na wstędze, o treści: • : S(igillum) FRATRIS • IOHANNIS • • ABBATIS • LVBENSIS • \&. Poszczególne elementy legendy zostały rozdzielone pojedynczymi guzami, a całość dopełnia ornament roślinny. Zwyczajowo napis wskazuje na właściciela pieczęci i jego pozycję we wspólnocie zakonnej.

Pieczęć mniejsza piesza opata Jana V znana jest z użycia z lat 1537-1538. Została przejęta po opacie Andrzeju. Dokonano tylko przerytowania imienia dysponenta tłoka ${ }^{59}$. Jej pierwsze dwa egzemplarze

${ }^{54}$ AP Wrocław, Rep. 135, nr D 219 (np. s. 103, 113, 126); Martin Sebastian Dittmans Chronik, s. 284; A. Schultz, Die Cistercienser-Klosterkirche zu Leubus, „Abhandlungen der Schlesischen Gesellschaft für Vaterländische Kultur, Philosophisch-historische Abtheilung", 1870, s. 83-84; K.K. Jażdżewski, Lubiąż, s. 74; R. Kaczmarek, Średniowieczne elementy wyposażenia i wystroju kościoła klasztornego Wniebowzięcia NMP w Lubiażu. Próba rekonstrukcji, w: Kościót klasztorny Wniebowzięcia NMP w Lubiążu. Historia, stan zachowania, koncepcja rewitalizacji, red. A. Kozieł, Wrocław 2010, s. 53-55.

${ }_{55}$ Tympanon wmurowany wtórnie w ścianę pałacu opatów lubiąskich (od strony dziedzińca), wybudowanego, jak przyjmuje literatura, w 1728 r. Obiekt znany autorowi z autopsji. Na temat domu opatów zob. K. Kalinowski, Kuria opatów lubiąskich w Legnicy, „Szkice Legnickie”, 6, 1971, s. 111-129.

${ }^{56}$ Inwentarz, nr 3.

57 Za pomoc w opisie elementów architektonicznych tej pieczęci oraz pieczęci większej stosowanej od rządów opata Mateusza Rudolfa serdecznie dziękuję dr. hab. A. Wagnerowi.

${ }^{58} \mathrm{~W}$ kwestii interpretacji tego rodzaju herbu przyjąłem argumentację P. Stróżyka, zbieżną z moimi obserwacjami dotyczącymi heraldyki klasztoru lubiąskiego; zob. tenże, Heraldyka opactwa cysterskiego w Łeknie-Wagrowcu, w: Cystersi łekneńscy w krajobrazie kulturowym ziem polskich w 850-lecie fundacji opactwa cysterskiego w Łeknie 1153-2003, red. A.M. Wyrwa, Łekno 2004, s. 89-104; tenże, Herby na pieczęciach cysterskich - wybrane zagadnienia, w: Pieczęcie herbowe - herby na pieczęciach, red. W. Drelicharz, Z. Piech, Warszawa 2011, s. 201-204.

59 Inwentarz, nr 4. 
zostały odciśnięte przez papier na podkładzie z wosku czerwonego na dokumentach z $1537 \mathrm{r}$. W formule sigillacyjnej zawartej $\mathrm{w}$ dokumencie z 1538 r. omawiana pieczęć została określona jako contrasigillum. Użyto jej w zastępstwie pieczęci większej, która nie znajdowała się w momencie wystawiania dokumentu w dyspozycji opata. Zachowana podstawa źródłowa nie potwierdza jednak jej zastosowania w roli pieczęci odwrocia, choć nie jest to wykluczone ${ }^{60}$.

Nowy opat Jan VI Hiller rządził opactwem w latach 1539-1552. Podobnie jak jego poprzednik stosował pieczęć większą ${ }^{61}$. Pieczęć została przejęta po poprzedniku i była stosowana bez wprowadzania zmian w obrazie i inskrypcji. Odpowiadała zapewne aspiracjom opata ukazania swojej wysokiej pozycji we wspólnocie i na zewnątrz klasztoru. Przejęcie tłoka po poprzedniku podkreślało też ciągłość władzy na urzędzie opata.

Nowością z okresu urzędowania opata Jana VI było stosowanie dwóch dodatkowych pieczęci. Jedna z nich, określona przeze mnie jako średnia, potwierdzona w użyciu w latach 1547-1549, została przejęta po poprzednim opacie i była stosowana bez wprowadzania zmian ${ }^{62}$. Druga zaś - owalna o wymiarach 21 x $18 \mathrm{~mm}$ - zachowała się w trzech egzemplarzach z lat 1540-1542 ${ }^{63}$. Pod względem ikonograficznym pieczęć jest nietypowa. W polu umieszczony został wyłącznie herb opacki: na tarczy szachowany dwurzędowy skos, nad nią położono infułę, a za nią pastorał. Było to czytelne wskazanie posiadania pontyfikaliów oraz herbu przez opata, co tym samym wyróżniało go, tak jak poprzedników, we własnej wspólnocie i w kontaktach $\mathrm{z}$ otoczeniem. Legenda umieszczana zwyczajowo w otoku została na omawianej pieczęci zastąpiona inicjałami wskazującymi w skrótowy sposób na opata i jego urząd.

Kolejny opat Jerzy z Legnicy (1552-1561) posługiwał się zapewne tą samą pieczęcią większą. Nie są jednak znane jak dotąd jej odciski ${ }^{64}$. Bliższe zbadanie pieczęci większej jego następcy pozwala jednak stwierdzić, że opat Jerzy zlecił częściowe przerytowanie tej pieczęci w miejscu daty. Na cokołach znajduje się bowiem inskrypcja $15 / 52^{65}$. Ów element chronologiczny wskazuje na czas wykonania pieczęci po elekcji opata Jerzego, która odbyła się w tym samym roku. Posiadanie tej samej pieczęci podkreślało przede wszystkim kontynuowanie dążeń poprzednich opatów do uwypuklenia swojej pozycji. Opat zlecił także zapewne przerytowanie legendy, aktualizując imię dysponenta pieczęci. Z okresu rządów opata Jerzego zachowała się za to jego pieczęć mniejsza herbowa. Jest to pieczęć owalna o wymiarach $21 \times 18 \mathrm{~mm}$, przywieszona do dokumentu z $1554 \mathrm{r}^{66}$ Podobieństwo do typu pieczęci herbowej stosowanej przez poprzedniego opata skłania do wniosku, że pieczęć została przerytowana tylko w miejscu występowania inicjałów.

Nowy opat Jan VII ${ }^{67}$, którego rządy przypadają na lata $1562-1568$, stosował w praktyce kancelaryjnej pieczęć większą przejętą po swoim poprzedniku. Dokonał tylko zmiany imienia w legendzie. Zachowane egzemplarze pochodzą z lat 1565-1566. Tym samym wskazywał na niezmienną pozycję opata we wspólnocie i utrzymał znany już odbiorcom obraz. W formułach sigillacyjnych pieczęcie określono jako większe opactwa, co wskazywało, że opat sprawował rządy w imieniu klasztoru ${ }^{68}$. Nie są znane jego inne pieczęcie, choć należy przyjąć, że również je stosował.

Kolejny opat w Lubiążu Jan VIII Klein (1568-1584) utrzymał również pieczęć większą po swoich poprzednikach. Nie zmienił też inskrypcji. Pieczęć ta poświadczona jest w użyciu w latach $1571-1581^{69}$.

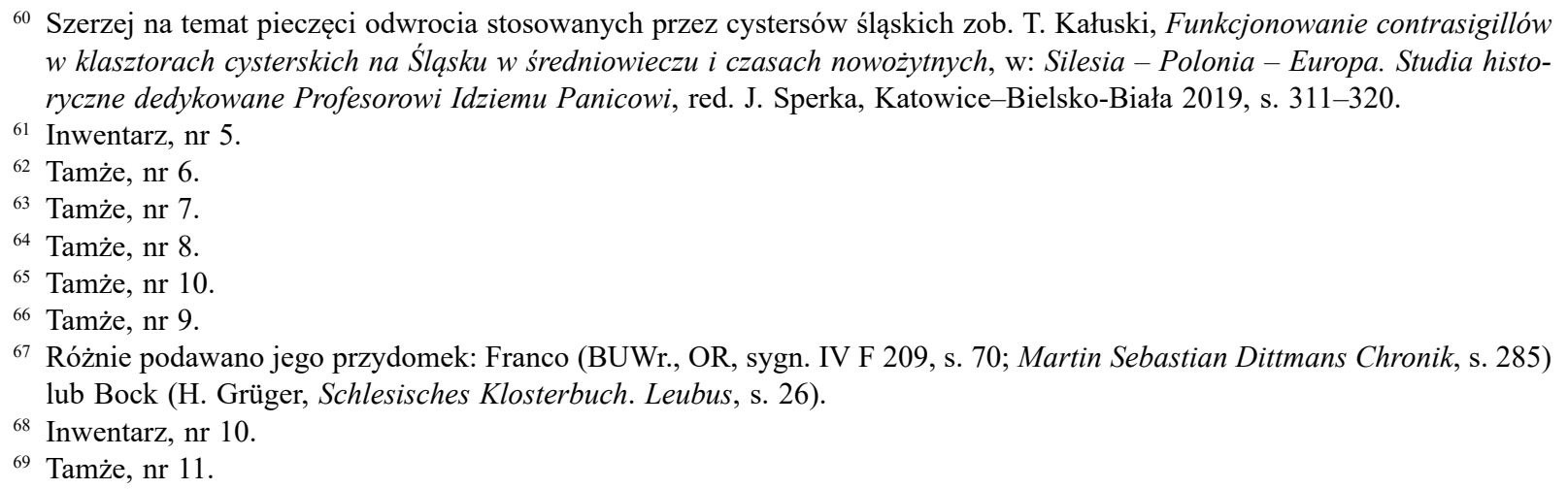


W formule sigillacyjnej w dokumencie z 1571 r. pieczęć została określona jako większa opactwa ${ }^{70}$. Szczególnie istotny jest dokument z 1579 r., wystawiony wraz z opatem Mikołajem z Henrykowa. Jako wizytatorzy swoich filii w Kamieńcu i Krzeszowie wydali oni zgodę Antoniemu opatowi z Kamieńca na sprzedaż lenna kościelnego w Wierzbnej Kasparowi opatowi z Krzeszowa ${ }^{71}$. Omawiany dokument wskazuje na bliskie relacje między klasztorami z jednej linii filiacyjnej, a także na zaangażowanie opata w sprawy poza klasztorem macierzystym. Jan VIII stosował również w praktyce kancelaryjnej pieczęć średnią pieszą $^{72}$, którą przejął po swoich poprzednikach. Jest ona znana z egzemplarza z $1582 \mathrm{r}$. Ekspozycja pontyfikaliów w obrazie pieczęci była na tyle atrakcyjna, że nie zachodziła potrzeba dokonywania zmian ${ }^{73}$. Opat stosował także pieczęć mniejszą herbową, określoną mianem sekretu opactwa. Pieczęć ma kształt owalny o wymiarach 17 x $15 \mathrm{~mm}$. Jej jedyny egzemplarz został odciśnięty przez papier na podkładzie z wosku czerwonego. W polu tej pieczęci wprowadzono herb urzędowy opata. Na tarczy położono szachowany dwurzędowy skos, na którym widnieje głowa św. Jana Chrzciciela na misie. Nad tarczą umieszczono infułę, a za nią pastorał oraz inicjały ${ }^{74}$. Pieczęć również wskazywała na wysoki status dysponenta pieczęci.

Po śmierci Jana VIII w 1584 r. rządy w klasztorze lubiąskim objął opat Hieronim Nikodem. Z jego czasów zachowała się pieczęć większa przy dokumencie z 1587 r., wystawionym z konwentem ${ }^{75}$. Opat zastosował tę samą strategię, co jego poprzednicy. Nie zlecił bowiem wykonania nowego tłoka, lecz posłużył się dawnym. Umieścił tylko swoje imię w legendzie. Korzystał też z pieczęci mniejszej herbowej, określonej jako sekret opactwa, z wizerunkiem herbu urzędowego opata (na tarczy szachowany dwurzędowy skos, a na nim głowa św. Jana Chrzciciela na misie), a powyżej umieszczono inicjały wskazujące na opata i jego pozycję. Pieczęć ta, o średnicy $18 \mathrm{~mm}$, została odciśnięta przez papier na podkładzie z wosku czerwonego na dokumencie z $1584 \mathrm{r}^{76}$

Kolejny opat Franciszek I Ursinus (1594-1607) w kwestii użycia pieczęci stosował podobną praktykę jak jego poprzednicy. Pieczęć większa, przejęta po poprzedniku, jest znana z odcisków zachowanych $\mathrm{z}$ lat $1602-1605^{77}$. Opat zwyczajowo zadbał tylko o przerytowanie imienia w jej legendzie. $\mathrm{Z}$ okresu jego rządów znana jest również pieczęć mniejsza herbowa o wymiarach 18 x $16 \mathrm{~mm}$. Jej egzemplarz został odciśnięty przez papier na podkładzie z wosku czerwonego na dokumencie z $1595 \mathrm{r}$. W polu tej pieczęci wyobrażony jest herb urzędowy opata: na tarczy szachowany dwurzędowy skos, na nim głowa św. Jana Chrzciciela na misie, nad tarczą wyeksponowano między inicjałami infułę, a za nią pastorał $^{78}$. Posiadane pontyfikalia oraz herb stanowiły również dla tego opata wyróżnik jego wysokiego statusu. Takie samo rozwiązanie wizualne przyjęto na innej pieczęci mniejszej herbowej, zachowanej jako środek zamknięcia listu z 1598 r. $^{79}$

\section{Przemiany ikonograficzne na pieczęciach opata Mateusza Rudolfa w pierwszej połowie XVII w.}

W 1607 r. po śmierci Franciszka opatem został wybrany Mateusz Rudolf z Hennersdorf. Doprowadził on do restytucji majątków klasztornych. Angażował się również poza klasztorem, sprawując urząd wikariusza generalnego na Śląsku w ramach wikariatu czesko-morawsko-łużycko-śląskiego ${ }^{80}$. Zerwał

\footnotetext{
${ }^{70}$ AP Wrocław, Rep. 83, nr 384.

71 Tamże, nr 392.

72 Zob. komentarz: Inwentarz, nr 6.

73 Tamże, nr 12.

74 Tamże, nr 13.

75 Tamże, nr 14.

76 Tamże, nr 15.

77 Tamże, nr 16.

78 Tamże, nr 17.

79 Tamże, nr 18.

${ }^{80}$ Wymieniona tytulatura opata występuje np. w dokumencie z 1630 r.; AP Wrocław, Rep. 91, nr 850; zob. też H. Grüger, Der Orden der Zisterzienser in Schlesien, s. 138.
} 
z tradycją przejmowania pieczęci większej po swoim poprzedniku. Zlecił bowiem wykonanie nowej, która zachowała się w dwóch oryginalnych odciskach z $1635 \mathrm{r}^{81}$ Jest to pieczęć ostroowalna o wymiarach 71 x $50 \mathrm{~mm}$. Pierwszy egzemplarz został wykonany w wosku czerwonym, dawniej był umieszczony w puszce drewnianej. Drugi został odciśnięty przez papier na podkładzie z wosku czerwonego. $\mathrm{W}$ polu pieczęci ukazano opata w kukulli z nałożonym na ramiona mucetem oraz infułą w typie pretiosa na głowie. W prawej ręce trzyma on pastorał, a w lewej zapewne Regułę. Postać stoi w renesansowej arkadzie, ustawionej na niewysokim postumencie, z kolumnami na profilowanych cokołach, trzonach z przewiązkami i podwójnymi kapitelami, nad którymi wznosi się profilowany łuk. W tle stojącego opata zaznacza się mniejsza edykuła (lub portal) zwieńczona konchą. Po bokach widać wysunięte cokoły, na których ustawiono dwa anioły w tunikach. Poniżej arkady umieszczony został herb klasztoru. Przedstawia on na tarczy dzielonej w krzyż pośrodku głowę św. Jana Chrzciciela na misie, w polu drugim i piątym szachowany dwurzędowy skos skrzyżowany z pastorałem, w polach trzecim i czwartym wspiętego burgundzkiego lwa za kratą. Pojawienie się herbu stanowiło istotny przełom w dziejach heraldyki klasztoru, gdyż do tego czasu opactwo nie posługiwało się własnym znakiem ${ }^{82}$. Legenda tej pieczęci została wyryta majuskułą humanistyczną w otoku: \& • S(igillum) : FRAT(ris) MATTHAEI RV/DOLPHI • ABBATIS - LVBENS(is) : \&. Poszczególne człony rozdzielają pojedyncze i podwójne guzy, a początek i koniec legendy dopełniają wici roślinne. Zwyczajowo inskrypcja wskazywała na właściciela pieczęci i jego urząd.

Z okresu rządów opata Mateusza Rudolfa znane są ponadto trzy inne pieczęcie. W porównaniu do poprzedników możemy zatem mówić o wzroście ich liczby. Opat używał pieczęci średniej pieszej, która zachowała się przy dokumencie z $1620 \mathrm{r}$. Ma ona średnicę $27 \mathrm{~mm}$ i została odciśnięta w wosku czerwonym $^{83}$. Obraz pieczęci nawiązuje do pieczęci opatów z XVI w. Przedstawia on bowiem opata w kukulli $\mathrm{z}$ nałożonym na ramiona mucetem $\mathrm{z}$ kapturem, który w prawej ręce trzyma pastorał o krzywaśni ozdobionej rozetą w wolucie oraz żabkami umieszczonymi na jej zewnętrznej krawędzi. Lewą ręką przytrzymuje Regułę, na głowie ma infułę. W otoku wyryto majuskulny napis: MATTHAEVS / ABBBAS LVBENSIS.

Kolejna pieczęć znana jest z kilkunastu odcisków z lat 1608-1630. Jest to pieczęć mniejsza herbowa, określona w źródłach jako sekret, o wymiarach 26 x $22 \mathrm{~mm}^{84}$. W obrazie napieczętnym umieszczono herb urzędowy opata, tak jak na pieczęciach wcześniejszych opatów. Nietypowa jest natomiast legenda umieszczona w otoku, wykonana majuskułą humanistyczną: MATTHAVS $\bullet 16 \bullet / 07 / \bullet$ ABBAS LVBENSIS. Poza wskazaniem na dysponenta tłoka wyryto na niej również element chronologiczny. Data wskazuje zapewne na czas wykonania typariusza oraz na wybór opata. Elekcja odbyła się bowiem 20 III 1607, co zostało następnie potwierdzone w kolejnych miesiącach przez cesarza Rudolfa, a biskup wrocławski Jan VI von Sitsch dokonał obrzędu benedykcji ${ }^{85}$. Najwcześniejszy znany dokument z tą pieczęcią pochodzi z 15 XII $1608^{86}$. Opat stosował ją dość często w kontaktach ze szlachtą w sprawach dotyczących regulacji granic między dobrami czy powinności poddanych klasztoru. Opat Mateusz kazał wykonać również inną pieczęć, której egzemplarz jest znany z $1611 \mathrm{r}$. Jest to pieczęć ośmioboczna o wymiarach 17 x $15 \mathrm{~mm}$, a jej odcisk wykonano przez papier na podkładzie z wosku czerwonego. W polu pieczęci umieszczono herb opacki, jak na wcześniejszej pieczęci mniejszej ${ }^{87}$.

${ }^{81}$ Inwentarz, nr 19.

${ }^{82}$ Dotychczas w literaturze przedmiotu pieczęć ta nie była uwzględniana. Pojawienie się herbu klasztornego łączono już z tym opatem, ale wskazano źródła pozasfragistyczne; zob. P. Stróżyk, Herby na pieczęciach, s. 207. Wcześniej błędnie też interpretowano wspięte lwy jako czeskie; zob. M.L. Wójcik, Heraldyka klasztorów cysterskich na Ślasku, w: Polska heraldyka kościelna. Stan i perspektywy badań, red. K. Skupieński, A. Weiss, Warszawa 2004, s. 43-58. Autor oparł się na ustaleniach H. Grügera; zob. tenże, Schlesisches Klosterbuch. Leubus, s. 28; tenże, Der Orden der Zisterzienser in Schlesien, s. 139. Na właściwą interpretację herbu opactwa naprowadza zapis ujęty w księdze prowadzonej w prepozyturze w Sicinach. Wymienione kwestie zostaną rozwinięte w przygotowywanej pracy poświęconej pieczęciom i heraldyce klasztorów cysterskich na Śląsku.

83 Inwentarz, nr 20.

${ }_{84}$ Tamże, nr 21.

${ }^{85}$ Dokumenty dawniej przechowywane w: AP Wrocław, Rep. 91, nr 778-780.

${ }^{86}$ Tamże, nr 782b.

${ }^{87}$ Inwentarz, nr 22. 
Opat Mateusz został przedstawiony nie tylko na swoich pieczęciach. Wyobrażono go również na płycie nagrobnej wykonanej za rządów jego następcy. Został tam ukazany w arkadzie, ubrany w kukullę z nałożonym mucetem, z „drogocenną” infułą na głowie oraz z pastorałem o ozdobnej krzywaśni, podtrzymywanym przez panniselus, w lewej ręce, i z księgą w prawej. Na dłoniach opata widoczne są rękawiczki pontyfikalne, a ponadto na palcach lewej - dwa pierścienie, z których jeden mógł być sygnetem. Po lewej stronie umieszczono herb klasztoru ${ }^{88}$. W powyższym wizerunku silnie zaakcentowano posiadane pontyfikalia, które miały za zadanie podkreślać wysoką pozycję opata, a elementy heraldyczne wskazywały, że działał on w imieniu klasztoru.

Opat Mateusz prowadził też działalność fundatorską w klasztorze. Zlecił wykonanie wyposażenia i wystroju kościoła klasztornego, które niestety uległo zniszczeniu podczas zajęcia klasztoru przez Szwedów w okresie wojny trzydziestoletniej ${ }^{89}$. Inskrypcje umieszczone na zachowanym ołtarzu bocznym i środkowej kwaterze innego ołtarza bocznego wskazują na tego właśnie opata jako fundatora ${ }^{90}$. Zdaniem Jana Harasimowicza podjęta przez niego aktywność świadczyła o potrzebie zaznaczenia miejsca klasztoru w społeczeństwie śląskim ${ }^{11}$. W literaturze przedmiotu wskazuje się też, że jego działalność fundacyjna była częścią „,pierwszej potrydenckiej ofensywy Kościoła katolickiego” na Śląsku². Na działania opata na tej płaszczyźnie należy również, moim zdaniem, spojrzeć przez pryzmat potrzeby zaznaczenia swojej dominującej pozycji w klasztorze.

\section{Opaci jako rządcy klasztoru w świetle ich pieczęci (XVII - pierwsza połowa XVIII w.)}

Nowym opatem został wybrany w 1636 r. Arnold Freiberger ze Spandau. Aktywnie działał na rzecz klasztoru. Odbudował wsie klasztorne, zakupił dobra i spłacił długi klasztoru ${ }^{93}$. Jego pozycja uległa również dalszemu wzmocnieniu po mianowaniu go przez opata generalnego w 1649 r. na urząd wikariusza generalnego na Śląsku. W kolejnych latach działał już w ramach utworzonego w $1651 \mathrm{r}$. wikariatu śląskiego ${ }^{94}$. Naraził się jednak na oskarżenia, nie wykonując należycie obowiązków związanych z pełnionym urzędem ${ }^{95}$. Koncentrował się bowiem na zarządzaniu opactwem, m.in. zaniedbując uczestnictwo w życiu duchowym swojej wspólnoty czy nie zezwalając na wizytacje klasztoru przez wikariusza generalnego, tolerował także protestantów w Lubiążu' ${ }^{96}$. W schyłkowym okresie swoich rządów zawarł też porozumienie z protestanckimi Piastami z linii legnicko-brzeskiej, zapewniające im wpływ na wybór opata, co należy traktować jako przejaw jego antyhabsburskiego nastawienia.

${ }^{88}$ P. Stróżyk, Symbole władzy opata, s. 51; A. Kolbiarz, A. Kozieł, Barokizacja wystroju i wyposażenia kościoła klasztornego Wniebowzięcia NMP w Lubiążu, w: Kościót klasztorny Wniebowzięcia NMP w Lubiążu, s. 85-87, 560-561, nr kat. L.V; R. Barczyński, Sztuka sepulkralna śląskich cystersów i dobroczyńców ich klasztorów w XVI w. i 1 połowie XVII w., w: Dzieje i kultura cystersów w Polsce 2, s. 233-234, 244 (w cyt. artykule niepoprawna identyfikacja herbu z płyty nagrobnej, który powiązano z opatami lubiąskimi oraz nieprecyzyjne określenie pełnionego przez opata urzędu wikariusza).

${ }^{89}$ Martin Sebastian Dittmans Chronik, s. 286-287; K. Kalinowski, Lubiąż, Wrocław 1970, s. 45; K.K. Jażdżewski, Lubiąż, s. $77-78$.

90 A. Kolbiarz, A. Kozieł, Barokizacja wystroju i wyposażenia kościoła, s. 83-88.

91 J. Harasimowicz, Rola klasztorów cysterskich w ksztaltowaniu się tożsamości kulturowej Śląska w dobie nowożytnej, w: Krzeszów uświęcony taska, red. H. Dziurla, K. Bobowski, Wrocław 1997, s. 165.

92 A. Kolbiarz, A. Kozieł, Barokizacja wystroju i wyposażenia kościoła, s. 83; zob. też. A. Kolbiarz, Między Pragą a Legnica. Matthäus (Matthias) Knote. Śląski rzeźbiarz epoki baroku i jego warsztat, Legnica 2017, s. 54.

${ }^{3}$ Martin Sebastian Dittmans Chronik, s. 288-290; K. Kalinowski, Lubiąż, s. 18.

${ }^{94}$ AA Wrocław, sygn. VB4a, bpag.; Statuta capitulorum, t. 7, 1651/83; A. Rose, Kloster Grüssau, Stuttgart-Aalen 1974, s. 79; H. Grüger, Ursachen und Folgen der Trennung Schlesiens von der Ordensprovinz Böhmen, „Cîteaux”, 27, 1976, s. 48; tenże, Heinrichau, s. 186; A. Galar, W europejskiej wspólnocie cysterskiej. Udziat cystersów z historycznych ziem polskich w Kapitułach Generalnych w Cîteaux (XII-XVIII w.), Kraków 2014, s. 361.

${ }_{95}$ H. Grüger, Der Orden der Zisterzienser in Schlesien, s. 129-130. Opat nie wizytował innych klasztorów oraz nie zwoływał kapituł prowincjonalnych. Został za to zawieszony w $1661 \mathrm{r}$.

96 Tenże, Heinrichau, s. 187. 
Jego poczynania w klasztorze oraz wspomniana umowa wywołały sprzeciw lokalnego środowiska cystersów oraz ostatecznie kapituły generalnej ${ }^{97}$.

Opat Arnold przejął pieczęć większą po swoim poprzedniku i stosował ją zapewne przez cały okres swoich rządów. Zachowała się ona w odciskach z lat 1645-1656. Dla jego potrzeb dokonano częściowego przerytowania legendy w początkowych jej partiach, w tym imienia opata ${ }^{98}$. Jeden $z$ dokumentów uwierzytelnionych tą pieczęcią dotyczył potwierdzenia elekcji opata w Jemielnicy w $1645 \mathrm{r}$. Pod nieobecność opata Arnolda wyborom, podczas których opatem wybrano profesa i przeora rudzkiego, przewodniczyli opaci z Henrykowa i Rud ${ }^{99}$. Dokument został wystawiony przez opata Arnolda, a pieczęcie poza nim przywiesili opaci z Henrykowa i Rud oraz konwent jemielnicki ${ }^{100}$. Tego typu wydarzenia wskazują na silne więzi łączące klasztory z całego Śląska. Sprzyjało to również przejmowaniu wykorzystanych już wizerunków przez opatów nie tylko z klasztorów wywodzących się z Lubiąża, ale także między przełożonymi opactw z Dolnego i Górnego Śląska.

Opat Arnold posługiwał się podczas swoich rządów jeszcze czterema pieczęciami mniejszymi. Wszystkie reprezentują typ herbowy. Na najstarszej z nich, o wymiarach 21 x $19 \mathrm{~mm}$, potwierdzonej w użyciu w 1638 r., wyobrażony został herb urzędowy opata, a nad tarczą wyryto inicjały ${ }^{101}$. Na kolejnej mniejszej, o wymiarach 26 x $23 \mathrm{~mm}$, znanej z wielu odcisków z lat 1648-1672, przedstawiono po raz pierwszy na tego rodzaju pieczęciach herb opactwa. Nad tarczą ukazano infułę w typie pretiosa, a za nią pastorał, co wskazywało na wysoki status opata. Było to też zgodne z tendencjami występującymi w nowożytnej heraldyce kościelnej, które polegały na umieszczaniu nad herbami instytucji kościelnych tego typu elementów ${ }^{102}$. W otoku opisywanej pieczęci wyryto inskrypcję wskazującą na właściciela pieczęci: [FR(ater) • ] ARNOLDVS • / ABBAS • LVBENSIS • • ${ }^{103}$. Herb klasztoru umieszczony został również na dwóch innych pieczęciach mniejszych, z czego pierwsza jest znana z dwóch egzemplarzy z lat $1652-1654^{104}$, a druga z $1671 \mathrm{r}$. Na ostatniej z nich umieszczono ponadto nad tarczą inicjały wskazujące na opata $A$ rnolda $^{105}$. Częstotliwość użycia pieczęci mniejszych wzrosła wyraźnie w drugiej połowie XVII w., co było wynikiem powrotu opata z konwentem z Wrocławia w 1649 r. Pobyt poza klasztorem był konsekwencją zajęcia go podczas wojny trzydziestoletniej przez Szwedów w 1639 r. ${ }^{106}$ Opat Arnold stosował na pieczęciach, podobnie jak jego poprzednik, herb urzędowy opata oraz klasztoru. Rozszerzył jednak użycie tego ostatniego znaku na pieczęcie mniejsze. $\mathrm{Z}$ jednej strony umożliwiało to konstruowanie własnej tożsamości, a $\mathrm{z}$ drugiej podkreślało jego związek z klasztorem.

Opat prowadził też działalność fundacyjną, która poza wymiarem praktycznym - odnowienia klasztoru po wojnie trzydziestoletniej - odzwierciedlała jego silną pozycję we wspólnocie i na zewnątrz, a także ważną rolę, jaką odgrywało opactwo na Śląsku. Dokonał renowacji kościoła klasztornego oraz

${ }_{97}$ Tamże, s. 187-188; J. Harasimowicz, Rola klasztorów cysterskich, s. 165; A. Galar, Sprawy opactw cysterskich w Rzeczypospolitej i na Śląsku na Kapitułach Generalnych w Cîteaux w XVII i XVIII w., w: Dzieje i kultura cystersów w Polsce 2, s. 491. Wskazano też w literaturze ciekawą koncepcję wykorzystania przez opata Arnolda działalności fundacyjnej do obrony swojej pozycji po ujawnieniu jego porozumienia z Piastami; zob. A. Kolbiarz, Między Praga a Legnica, s. $75-76$.

98 Inwentarz, $\mathrm{nr} 23$.

99 Opat Arnold wytłumaczył swoją nieobecność podczas elekcji niebezpieczeństwem podróżowania i napadami wojsk szwedzkich.

${ }^{100}$ AP Wrocław, Rep. 85, nr 58. Obecnie brakuje pieczęci konwentu z Jemielnicy. Zachował się też drugi egzemplarz tego dokumentu, pozbawiony pieczęci; zob. tamże, nr 57.

${ }^{101}$ Inwentarz, $\mathrm{nr} 24$.

102 P. Dudziński, Współczesna heraldyka i zwyczaje heraldyczne w kościołach chrześcijańskich, t. 1, Warszawa 2007, s. 150$-152,210$.

${ }^{103}$ Inwentarz, $\mathrm{nr} 25$.

104 Tamże, nr 26.

${ }_{105}$ Tamże, nr 27.

${ }^{106}$ Martin Sebastian Dittmans Chronik, s. 287; H. Grüger, Schlesisches Klosterbuch. Leubus, s. 9. Związek z tymi wydarzeniami miało wystawienie dokumentu w 1651 r., w którym opat wraz z prepozytami potwierdził sprzedaż folwarku, zapisanego opactwu przez kanclerza klasztornego, mieszczaninowi z Wrocławia, który wspierał opata i klasztor od 1637 r.; zob. AP Wrocław, Rep. 91, nr 865. 
przywrócił jego wyposażenie, a także częściowo przebudował klasztor ${ }^{107}$. Zlecił też zapewne wykonanie omówionej wcześniej płyty nagrobnej swojego poprzednika, opata Mateusza. Część fundacji podkreśla bezpośrednio pozycję opata poprzez umieszczenie na obiektach inskrypcji oraz herbów. Znamienne jest, jak zauważył Andrzej Kozieł, że prawie wszystkie obrazy zamówione przez opata Arnolda u Michaela Willmanna zawierają jego inicjały oraz często również herby ${ }^{108}$. Najczęściej były to urzędowe herby opata. Widoczne są m.in. na płótnach pełniących zapewne funkcje obrazów ołtarzowych, które pierwotnie umieszczone były w kościele klasztornym ${ }^{109}$, oraz na większości obrazów z cyklu Męczeństwa apostołów, namalowanych w okresie rządów opata Arnolda, pierwotnie stanowiących jeden z głównych elementów wystroju tego kościoła ${ }^{110}$.

Opat Arnold zamanifestował także swoją wysoką pozycję posiadaniem własnego księgozbioru, z którego część książek przekazał później do biblioteki klasztornej ${ }^{111}$. Książki oznaczał ekslibrisami oraz superekslibrisami ${ }^{112}$. Znane są mi dwie odmiany superekslibrisów herbowych, uzupełniane zwykle przez superekslibrisy napisowe. Pierwszy wariant zawiera motyw herbu opactwa z umieszczoną nad tarczą infułą oraz widoczną krzywaśnią pastorału. W otoku został umieszczony napis wskazujący, że herb odnosi się do opata lubiąskiego Arnolda: * INSIGNIA • ABBATIS • LVBENSIS • A(rnoldi) • A(bbatis) - $\mathrm{F}$ (ratris) $\bullet \mathrm{F}$ (reiberger) $\bullet 1640^{113}$. Wymieniony księgoznak występował też jako ekslibris, ze znanego mi przykładu, na efektownej czerwonej karteczce ${ }^{114}$. Drugi wariant superekslibrisu herbowego przedstawia również herb klasztoru, powyżej infułę, a za tarczą pastorał, całość zwieńczono wstęgą z napisem: ARNOLD(us) ABB/AS - LVBENS(is), a u dołu herbu wyciśnięto datę 1/6/47 $7^{115}$. Wymienione znaki własnościowe, co ważne, naśladowały pieczęcie mniejsze herbowe opata Arnolda. Część superekslibrisów wykonana była w technice wycisku złotego, co jeszcze bardziej podkreślało wysoki status opata.

Nowym opatem, po śmierci Arnolda, został wybrany w 1672 r. Jan IX Reich. Podobnie jak jego poprzednik, przejął on również po zmarłym opacie pieczęć większą. Zlecił jednak całościowe przerytowanie napisu legendy. Pod względem treści wprowadził wszakże te same elementy. Pieczęć ta jest potwierdzona w użyciu w kilku oryginalnych odciskach aż do śmierci opata w 1691 r. ${ }^{116}$

Stosował on również trzy pieczęcie mniejsze herbowe. Najstarsza z nich zachowała się w formie tłoka wykonanego z żelaza o wymiarach 27 x $26 \mathrm{~mm}$. Typariusz został w górnej części rozbity, co świadczy o jego częstym stosowaniu w praktyce kancelaryjnej. Pieczęć znana jest jednak tylko $z$ dwóch odcisków z lat 1674 i $1681^{117}$. W jej polu wyobrażono herb opactwa, za tarczą położono pastorał, a powyżej infułę w typie pretiosa. W otoku wyryto inskrypcję wskazującą na dysponenta tłoka: FR(ater) : $\mathrm{IO}(h)$ ANNES • ABBAS • LVBENSIS • Kolejne dwie pieczęcie zachowały się w odciskach z lat 80 . XVII w. Ich obraz jest analogiczny do omówionej powyżej pieczęci ${ }^{118}$. Na drugiej z nich, ze względu na mniejsze rozmiary, wprowadzono jedynie inicjały wskazujące na jej dysponenta.

${ }^{107}$ Martin Sebastian Dittmans Chronik, s. 287-291; K. Kalinowski, Lubiąz, s. 18-20; A. Kolbiarz, A. Kozieł, Barokizacja wystroju i wyposażenia kościoła, s. 88-89.

108 A. Kozieł, Michael Willmann i jego malarska pracownia, Wrocław 2013, s. 45-47, 92.

109 A. Kolbiarz, A. Kozieł, Barokizacja wystroju i wyposażenia kościoła, s. 496-499, nr kat. J. III-J. IV; A. Kozieł, Michael Willmann, s. 402-403, nr kat. A. 216, s. 425-426, nr kat. A. 230.

110 A. Kolbiarz, A. Kozieł, Barokizacja wystroju i wyposażenia kościoła, s. 91, 476-488, 491-493, nr kat. J.I.I-J.I.7, J.I.9; A. Kozieł, Michael Willmann, s. 390-392, nr kat. A. 208-A. 209, s. 401, nr kat. A. 215, s. 404-406, nr kat. A. 218-A. 219, s. 409-413, nr kat. A. 221-A. 223, s. 418-423. Za udostępnienie zdjęć detali wzmiankowanych obrazów z okresu rządów opata Arnolda oraz Ludwika Baucha serdecznie dziękuję prof. Andrzejowi Koziełowi.

111 Martin Sebastian Dittmans Chronik, s. 291.

112 Zob. zestawienie książek ze znakami własnościowymi opata Arnolda: R. Šípek, Die Jauerer Schlossbibliothek Ottos des Jüngeren von Nostitz, t. 2, Frankfurt am Main 2014.

113 BUWr., OR, sygn. 467097, 467497, 467184, 470335, 471301.

114 Tamże, sygn. 471181 II.

115 Tamże, sygn. 479866, 480350, 482520, 483012, 483081. Podobiznę i opis omawianego superekslibrisu zob. E. Chwalewik, Exlibrisy polskie szesnastego i siedemnastego wieku, Wrocław 1955, s. 71-72, il. po s. 157.

116 Inwentarz, nr 28.

117 Tamże, nr 29.

118 Tamże, nr 30, 31. 
Wysoka pozycja opata Jana została również zamanifestowana poprzez aktywną działalność fundatorską. Rozpoczął on bowiem budowę nowego klasztoru, zaczynając od wznoszenia dwuskrzydłowego pałacu opatów. Dokonał także dzieła przebudowy kościoła klasztornego, fundując najważniejsze elementy wyposażenia, ze słynnymi stallami anielskimi na czele i związanymi z nimi dwiema lożami opackimi ${ }^{119}$. Jego działania zostały podkreślone stosowną inskrypcją na kartuszu, zwieńczonym infułą, umieszczonym pod emporą organową w kościele klasztornym. W przekształconej później treści wymieniono kolejnych modernizatorów świątyni, opata Ludwika Baucha oraz Wilhelma Steinera ${ }^{120}$. Opat Jan rozbudował również bibliotekę klasztorną, kontynuując dzieło swojego poprzednika ${ }^{121}$.

Z czasów krótkotrwałych rządów opata Dominika Krausenbergera (1691-1692) znane są tylko dwie jego pieczęcie mniejsze herbowe. Do czasów współczesnych przetrwał typariusz, a także szereg kopii wykonanych z tego tłoka. Typariusz o wymiarach 30 x $29 \mathrm{~mm}$ został sporządzony ze srebra i żelaza ${ }^{122}$. Obraz pieczęci, tak samo jak poprzedników opata Dominika, przedstawia herb opactwa. Nad tarczą umieszczono infułę $\mathrm{w}$ typie pretiosa, a za nią pastorał. W otoku wyryto legendę odnoszącą się do dysponenta pieczęci i jego urzędu: FR(ater) : DOMINICUS ABBAS LUBENSIS. Druga pieczęć zachowała się $\mathrm{w}$ egzemplarzu wyciętym $\mathrm{z}$ dokumentu. Jest to również pieczęć $\mathrm{z}$ wyobrażeniem herbu opactwa i napisem biegnącym $\mathrm{w}$ otoku o takiej samej treści jak na poprzedniej pieczęci ${ }^{123}$.

Jak dotąd nie są znane pieczęcie kolejnego opata Balthasara Nitschego (1692-1696). Zapewne mieściły się w ramach strategii wizualnej wykorzystywanej przez opatów na pieczęciach większych i mniejszych.

Jego następca opat Ludwik Bauch (1696-1729) prowadził, wzorem swoich poprzedników, aktywną działalność na płaszczyźnie gospodarczej. Szczególnie istotne było odkupienie przez niego wraz z konwentem dawnych wsi klasztornych, Pomocne i Mysłowa, z rąk lokalnej szlachty ${ }^{124}$. Opat generalny mianował ponadto opata Ludwika wikariuszem generalnym. Podobnie jak opat Arnold, prowadził on samodzielną politykę, narażając się na interwencję opata generalnego ${ }^{125}$.

Ludwik Bauch utrzymał podczas swoich rządów w opactwie pieczęć większą po swoich poprzednikach. Potwierdzona jest ona w użyciu przez cały okres jego rządów ${ }^{126}$. Zlecił jedynie przerytowanie początkowych wyrazów legendy oraz imienia, aby zaktualizować typariusz. Wzorem poprzednich opatów używał także pieczęci mniejszych $\mathrm{z}$ herbem opactwa, podkreślając poprzez dodanie infuły oraz pastorału wysoką pozycję klasztoru oraz swoją. Jedna z pieczęci, o wymiarach $30 \times 27 \mathrm{~mm}$, zawiera wokół otoku inskrypcję wskazującą na opata: * FR(ater) : LVDOVICVS • ABBAS • LVBENSIS *127. Pozostałe trzy pieczęcie mają w polu inicjały odnoszące się do przełożonego klasztoru ${ }^{128}$. Dwie z nich są poświadczone w użyciu przez niemal cały okres rządów opata Ludwika.

Podkreślił on także swoją wysoką pozycję w opactwie na płaszczyźnie fundatorskiej. Dokończył przede wszystkim barokizację wnętrza kościoła klasztornego i kaplicy książęcej, ufundował do nich ołtarze, a także zlecił wykonanie paramentów liturgicznych. Zamówił też u Michaela Willmanna pozostałe obrazy z cyklu Męczeństw apostołów. Na trzech z nich, na których widnieją wyobrażenia heraldyczne, wprowadzono herby opactwa z inicjałami opata. Podkreślono zatem jego przewodzenie klasztorowi ${ }^{129}$. Wraz z zakończeniem

\footnotetext{
119 A. Kolbiarz, A. Kozieł, Barokizacja wystroju i wyposażenia kościoła, s. 93-103. Na s. 94-95 jest podana inna ocena, niż w niniejszym tekście, przyczyn podjęcia działalności fundatorskiej przez opata Jana IX.

120 Tamże, s. 100, 111, 182-183, nr kat. A.IV.

${ }^{121}$ Martin Sebastian Dittmans Chronik, s. 291.

122 Inwentarz, nr 32.

123 Tamże, nr 33.

124 AP Wrocław, Rep. 91, nr 1098, 1161; Martin Sebastian Dittmans Chronik, s. 293-294.

${ }^{125}$ H. Grüger, Heinrichau, s. 188. Odmiennie niż opat Arnold, wizytował podległe mu klasztory, ale odmawiał wizytowania własnego opactwa. Uważał, że jakiekolwiek zależności ustały w momencie sekularyzacji macierzy Lubiąża - klasztoru w Pforcie - w pierwszej połowie XVI w.

${ }^{126}$ Inwentarz, nr 34.

127 Tamże, nr 36.

128 Tamże, nr 35, 37-38.

129 A. Kolbiarz, A. Kozieł, Barokizacja wystroju i wyposażenia kościoła, s. 106-111, 488-490, nr kat. J.I.11, J.I.12, J.I.15; A. Kozieł, Michael Willmann, s. 413-416, nr kat. A. 225-A. 226, s. 431-432, nr kat. A. 234.
} 
budowy pałacu opat Ludwik polecił również umieszczenie herbu klasztoru nad zwornikiem portalu w skrzydle zachodnim ${ }^{130}$. Podkreślił tym samym swoje znaczenie w kierowaniu klasztorem. Za jego rządów, jak wskazują ostatnie badania, wykonano także freski w kaplicy książęcej. Ich wymowa wskazywała nie tylko na kult fundatora i dynastii piastowskiej, ale wyrażała też zapewne aspiracje opata do utrzymania szczególnej pozycji klasztoru na Śląsku i niezależności wobec absolutystycznej polityki Habsburgów ${ }^{131}$.

Z okresu rządów kolejnego opata Dominika II Süßmutha (1729-1732) zachowała się tylko jego pieczęć mniejsza o wymiarach 19 x $16 \mathrm{~mm}$, z wizerunkiem herbu opactwa i dodanymi powyżej inicjałami. Jest ona poświadczona w użyciu w 1730 r. ${ }^{132}$

W 1733 r. opatem w Lubiążu został wybrany Konstantyn Beyer ${ }^{133}$. Ściślejsze związki z Habsburgami wykorzystał on z pożytkiem dla klasztoru. Już na początku swoich rządów uzyskał bowiem od Karola VI potwierdzenie nabytych przez jego poprzednika dwóch wiosek (Pomocne i Mysłowa). Otrzymał również zgodę na zakup Sichowa, który klasztor sprzedał jeszcze w średniowieczu ${ }^{134}$. Transakcję przeprowadzono w 1734 r. ${ }^{135}$, a dokument został opieczętowany jedną z pieczęci mniejszych opata ${ }^{136}$.

W praktyce kancelaryjnej opat Konstantyn posługiwał się pieczęcią większą, przejętą po poprzednikach. Zlecił jedynie przerytowanie początkowych wyrazów legendy oraz imienia ${ }^{137}$. Symbolicznie podkreślił tym samym stabilność i ciągłość rządów opatów w klasztorze. Posługiwał się ponadto trzema pieczęciami mniejszymi z wizerunkiem herbu opactwa, z dodaniem zwyczajowo infuły i pastorału. Na jednej z pieczęci, o wymiarach $29 \times 27 \mathrm{~mm}$, w otoku wyryto inskrypcję wskazującą na przełożonego klasztoru: CONSTANTINVS ABBAS LVBENSIS \& ${ }^{138}$. Na pozostałych wprowadzono inicjały odnoszące się do dysponenta pieczęci ${ }^{139}$.

Opat Konstantyn wyróżnił się we wspólnocie oraz na zewnątrz, wzorem swoich poprzedników, także na płaszczyźnie fundatorskiej. Na uwagę zasługuje przede wszystkim wystrój Sali Książęcej, gloryfikujący Habsburgów, Piastów i wiarę katolicką ${ }^{140}$. Nie zapomniano jednak uwydatnić wysokiej pozycji klasztoru i jednocześnie opata działającego w jego imieniu, wprowadzając herb opactwa w wyeksponowanych miejscach (zwieńczenie portalu, plafon). Ukazano go także wraz z herbem konwentu podtrzymywanym przez uskrzydlonego anioła (na tarczy dzielonej w pas w polu pierwszym ręka $\mathrm{z}$ pastorałem, pole drugie szachowane) nad emporą ${ }^{141}$. Moim zdaniem na czas rządów tego opata przypada umieszczenie takich samych herbów w górnej partii fasady kościoła klasztornego. Zostały one przedstawione po obu stronach dwugłowego orła cesarskiego, który miał podkreślać opiekę Habsburgów nad opactwem ${ }^{142}$.

\section{Kontynuacja wyobrażeń na pieczęciach opatów od polowy XVIII w. do 1810 r.}

Działalność prohabsburska opata Konstantyna, która wzmocniła pozycję jego samego oraz klasztoru, zaważyła niewątpliwie na jego dalszych losach po zajęciu przez Prusy Śląska w 1740 r. Decyzją

${ }^{130}$ K. Kalinowski, Lubiąz, s. 91-92, 95, 101-102.

131 A. Kozieł, Dekoracja freskowa Kaplicy Książęcej, w: Kościót klasztorny Wniebowzięcia NMP, s. 587.

${ }_{132}$ Inwentarz, nr 39.

133 AP Wrocław, 83, nr 882; Martin Sebastian Dittmans Chronik, s. 295. W literaturze podano błędną datę elekcji, wskazując na 1732 r.; zob. H. Grüger, Schlesisches Klosterbuch. Leubus, s. 27.

${ }^{134}$ BUWr., OR, sygn. IV F 209, s. 155-156, 164; Martin Sebastian Dittmans Chronik, s. 295.

135 AP Wrocław, Rep. 91, nr 1205.

${ }^{136}$ Inwentarz, $\mathrm{nr} 41$.

137 Tamże, nr 40.

138 Tamże, nr 43.

139 Tamże, nr 41-42.

140 B. Lejman, „Feminizm” programu treściowego Sali Książęcej, w: Opactwo cystersów w Lubiążu i artyści, red. A. Kozieł, Wrocław 2008, s. 315-331.

${ }^{141}$ K. Kalinowski, Sala Książęca opactwa cysterskiego w Lubiążu, Wrocław 2001, po s. 42, fot. 1, $14,17$.

${ }^{142}$ Tenże, Lubiąż, s. 60. Na temat końcowego etapu przebudowy kościoła klasztornego zob. E. Łużyniecka, Architektura klasztorów cysterskich. Filie lubiąskie i inne cenobia śląskie, Wrocław 2002, s. 83. 
Fryderyka II z 18 II 1747 został on zmuszony do rezygnacji z urzędu. W jego miejsce konwent dokonał w kolejnym miesiącu wyboru trzech kandydatów. Nominowanym i zatwierdzonym przez króla na opata został ostatecznie preferowany przez niego Tobiasz Stusche, który sprawował jednocześnie rządy w klasztorze w Kamieńcu ${ }^{143}$.

Wybrany opat jeszcze w 1747 r. wykonał dwie pieczęcie mniejsze. Wyobrażają one herb opactwa z wyeksponowaną infułą nad tarczą, a za nią widoczna jest krzywaśń pastorału. Nad tarczą wyryto również inicjały wskazujące na dysponenta pieczęci ${ }^{144}$. Tłok jednej z pieczęci, o wymiarach $22 \mathrm{x} 20 \mathrm{~mm}$, zachował się do obecnych czasów. Typariusz został wykonany z żelaza ${ }^{145}$. Opat Tobiasz zlecił również wykonanie trzeciego tłoka, o wymiarach $21 \times 19 \mathrm{~mm}$. Przedstawia on w polu pieczęci herb urzędowy opatów z inicjałami nad tarczą. Płytka tłoka została wykonana ze srebra, a uchwyt z żelaza ${ }^{146}$. Tobiasz Stusche sięgnął zatem po wyobrażenie, które nie pojawiało się na pieczęciach opackich od czasów rządów opata Arnolda. Niewątpliwie było bardziej wyrazem aspirowania do pozycji, jaką osiągnęli poprzedni opaci niż realnych wpływów w klasztorze. Opat Tobiasz był bowiem uważany przez mnichów, ze względu na zażyłe kontakty z królem pruskim, za intruza ${ }^{147}$. Należy zaznaczyć, że taką samą strategię przyjął on w klasztorze kamienieckim. Na pucharze wykonanym na jego zlecenie umieszczono bowiem również herb opacki, a nie klasztorny ${ }^{148}$. Z podjętej przez niego działalności fundatorskiej w Lubiążu wyróżnia się budynek prepozytury w Sicinach. Dokończył on budowę rozpoczętą przez poprzednika, a nad portalem wejścia głównego został umieszczony herb klasztoru zwieńczony infułą oraz herb konwentu ${ }^{149}$. Symbole te podkreślały przynależność placówki do Lubiąża, a herb klasztoru z umieszczonymi powyżej inicjałami - przewodzenie klasztorowi przez opata.

Po śmierci Tobiasza w 1757 r. na opata został wybrany i następnie zatwierdzony Wilhelm Steiner. Podczas swoich rządów pełnił również funkcję wikariusza generalnego. $\mathrm{Z}$ jego czasów zachowała się pieczęć większa. Przejął on pieczęć większą po poprzednikach. Dokonał jednakże całościowego przerytowania legendy. Napis rozpoczynał się wówczas u dołu pieczęci i zmieniona została jego treśćc 150 .

Poza pieczęcią większą $\mathrm{w}$ praktyce kancelaryjnej znalazły zastosowanie pieczęcie mniejsze, $\mathrm{z}$ których największa mierzyła 24 x $22 \mathrm{~mm}$, z wizerunkiem herbu opactwa oraz inicjałami odnoszącymi się do dysponenta pieczęci. Pierwsza z nich jest poświadczona w praktyce kancelaryjnej już w $1757 \mathrm{r}$. Nowością było zwieńczenie herbu kapeluszem rangowym ze sznurami, wiązaniami i chwostami po sześć w układzie 1, 2, 3. Omawiana pieczęć została następnie częściowo przerytowana. Na pieczęci znanej z egzemplarza z 1765 r. wprowadzono bowiem oprócz kapelusza infułę oraz pastorał ${ }^{151}$. Opat Wilhelm wykorzystał zatem możliwość podkreślenia posiadania pontyfikaliów oraz swojej wysokiej pozycji w opactwie, jak i samego klasztoru. Był to także objaw dopasowania się do ówczesnych zwyczajów heraldycznych. Wymienione powyżej wyobrażenie zostało wprowadzone również na inną pieczęć mniejszą ${ }^{152}$. Praktykę umieszczania dodatkowych elementów nad tarczą cechowała w tym okresie duża płynność. Stąd na trzeciej pieczęci nad herbem opactwa wyobrażono tylko infułę, a za tarczą pastorał ${ }^{153}$. Zacierało to dla odbiorcy różnicę między herbem opactwa a opata.

${ }_{143}$ GStA PK, I. HA Rep. 46 B Schlesien seit 1740, nr 168f, bpag.; Martin Sebastian Dittmans Chronik, s. 296.

144 Inwentarz, $\mathrm{nr} 44-45$.

145 Tamże, nr 44.

146 Tamże, $\mathrm{nr} 46$.

${ }^{147}$ H. Grüger, Schlesisches Klosterbuch. Leubus, s. 10; tenże, Upadek opactwa cystersów w Kamieńcu Ząbkowickim, w: 900 Jahre Kamenz - Kamieniec Zabkowicki. Spuren deutscher und polnischer Geschichte / 900 lat Kamieńca Ząbowickiego - Kamenz. Ślady niemieckiej i polskiej historii, Görlitz 1996, s. 38-39.

148 E.B. Grochowska, Puchar opata kamienieckiego Tobiasza Stusche (1695-1757) w Muzeum Narodowym we Wroctawiu, w: 900 Jahre Kamenz, s. 48-52 oraz fotografie; P. Stróżyk, Herby na pieczęciach, s. 201.

${ }^{149}$ Herby znane mi z autopsji; zob. też. M. Krzyżosiak, Ślady obecności cystersów lubiąskich na obszarze Dolnego Śląska na przykładzie wsi Siciny, cz. 4, „Kwartalnik Górowski”, 36, 2011, s. XV, il. 13 (tam błędna identyfikacja herbów).

150 Inwentarz, nr 47.

151 Tamże, nr 48, 51.

152 Tamże, nr 50 .

153 Tamże, nr 49. 
Kolejny opat Łukasz Springer, który stał na czele klasztoru w Lubiążu w latach 1769-1783 oraz pełnił urząd wikariusza generalnego, posługiwał się zwyczajowo pieczęcią większą swoich poprzedników. Z niewiadomych przyczyn nie dokonał jednak żadnych zmian w inskrypcji otokowej, pozostawiając imię zmarłego opata Wilhelma. Obraz pieczęci, jak i napis wskazywał zatem jednoznacznie na ciągłość władzy opackiej ${ }^{154}$. Opat Łukasz posługiwał się ponadto dwoma pieczęciami mniejszymi z wyobrażeniem herbu opactwa oraz inicjałami wskazującymi na właściciela tłoka. Na pierwszej z pieczęci wprowadzono ponadto nad tarczę infułę, a za nią pastorał ${ }^{155}$. Na drugiej rozbudowano zaś dodatki herbowe, tak samo jak u opata Wilhelma, co rzutowało na jej większe rozmiary ( 29 x $26 \mathrm{~mm})$. W jej polu umieszczono bowiem nad infułą i pastorałem kapelusz rangowy ze sznurami, wiązaniami i chwostami po sześć w układzie $1,2,3^{156}$.

Przedostatnim opatem przed sekularyzacją klasztoru był Franciszek Großpietsch (1783-1794), który pełnił, tak jak jego poprzednik, urząd wikariusza generalnego. Z 1793 r. zachował się egzemplarz pieczęci większej tego opata. Tak samo jak poprzednik, nie wprowadził żadnych zmian do pieczęci, pozostawiając imię opata Wilhelma ${ }^{157}$. Z okresu jego rządów znane są także pieczęcie mniejsze. Pierwsze dwie zachowały się w egzemplarzach z lat 1786-1790. Obraz pieczęci przedstawia herb opactwa. Zwyczajowo wyryto inicjały wskazujące na dysponenta typariusza ${ }^{158}$. Kolejne pieczęcie, górujące nad poprzednimi pod względem wymiarów, mają odmienne wyobrażenie. Przedstawiają, podobnie jak na wcześniejszej pieczęci opata Tobiasza oraz jego poprzedników z wcześniejszych stuleci, herb urzędowy opata ${ }^{159}$. Ponowne sięgnięcie po herb opacki podkreślający pozycję opata można interpretować w kontekście względnego rozwoju klasztoru za czasów opatów Łukasza i Franciszka, poddanego pod rządami królów pruskich wzmożonej polityce fiskalnej ${ }^{160}$.

Ostatni opat klasztoru w Lubiążu Gabriel Otto sprawował rządy od 1794 r. do momentu sekularyzacji opactwa w $1810 \mathrm{r}$. Z ostatniego roku istnienia opactwa zachowały się dwa odciski pieczętne o wymiarach 35 x $28 \mathrm{~mm}$ oraz wiele odcisków kolekcjonerskich, wykonanych zaginionym obecnie typariuszem. $\mathrm{Z}$ inwentarza archiwalnego dowiadujemy się, że wzmiankowany tłok sporządzony został z jaspisu oraz hematytu, a osadzono go w uchwycie wykonanym z czerwonego złota ${ }^{161}$. Kosztowny materiał służył podkreśleniu prestiżu właściciela pieczęci i pozycji opata. Wyobrażenie napieczętne przedstawia, tak jak na pieczęciach poprzednich opatów, herb klasztoru. Wyróżnia się majuskułowa legenda umieszczona w otoku: * SIGILLUM ABBATIAE LUBENSIS ${ }^{162}$. Formuły koroboracyjne zawarte $\mathrm{w}$ dokumentach opata wskazują, że pieczęć należała do niego. Płynność terminologiczna miała wskazywać zapewne, że opat zarządzał opactwem i reprezentował je w kontaktach z otoczeniem. Prawdopodobnie z okresu rządów tego opata pochodzi również zachowany do obecnych czasów typariusz kolejnej pieczęci mniejszej - z herbem opactwa i inskrypcją identyczną jak na wymienionej wcześniej pieczęci. Tłok o średnicy $27 \mathrm{~mm}$ został wykonany z mosiądzu i żelaza ${ }^{163}$.

\footnotetext{
154 Tamże, nr 52.

155 Tamże, nr 53.

156 Tamże, nr 54.

157 Tamże, nr 55.

158 Tamże, nr 56, 58.

159 Tamże, nr 57, 59.

160 A. Harc, L. Harc, E. Łużyniecka, Lubiąż, w: Monasticon Cisterciense Poloniae, t. 2: Katalog męskich klasztorów na ziemiach polskich i dawnej Rzeczpospolitej, red. A.M. Wyrwa, J. Strzelczyk, K. Kaczmarek, Poznań 1999, s. 208.

161 AP Wrocław, Kolekcja rękopisów Oddziału I, sygn. 369. Cytowany inwentarz sporządzono najpewniej przed przekazaniem kolekcji tłoków z ówczesnego Królewskiego Archiwum Państwowego we Wrocławiu do Muzeum Starożytności Śląskich w 1893 r. W innych zachowanych inwentarzach nie ujęto opisów typariuszy; zob. A. Hryniewicz, Trzy inwentarze śląskich typariuszy posekularyzacyjnych, „Roczniki Sztuki Śląskiej”, 25, 2016, s. 235-260.

${ }_{162}$ Inwentarz, $\mathrm{nr} 60$.

163 Tamże, nr 61 .
} 


\section{Podsumowanie}

Opaci z klasztoru w Lubiążu wykonali w okresie nowożytnym tylko dwa typariusze pieczęci większej, które były często przerytowywane w celu aktualizacji dysponenta tłoka. Pierwszy tłok, wykonany w pierwszej połowie XVI w., był stosowany do początku XVII stulecia, a drugi pozostawał w użyciu przynajmniej do schyłku następnego wieku. Wskazywało to na stabilność rządów opackich. Od czasów rządów Jana VI Hillera opaci dysponowali poza pieczęcią większą jeszcze dwoma dodatkowymi. Ich liczba wzrosła do czterech za rządów opata Arnolda Freibergera.

Zaprezentowane pieczęcie opackie odgrywały istotną rolę na płaszczyźnie wizualnej. Przeprowadzone badania świadczą bowiem, że wizerunki napieczętne wraz opatrującymi je inskrypcjami w otoku lub polu pieczęci manifestowały wysoką pozycję opatów. Umożliwiało im to również tworzenie ich tożsamości we wspólnocie zakonnej i na zewnątrz. Wyobrażenie św. Bernarda z Clairvaux wprowadzone na pieczęciach większych opatów w pierwszej połowie XV w. zostało w pierwszej połowie kolejnego stulecia zastąpione figurą samego opata. Podkreślało to sprawowanie rządów przez konkretną osobę. Odpowiadało też potrzebie ukazania wzrastającej pozycji opata w klasztorze. Przedstawienia figuralne utrzymały się, co ważne, aż do schyłku XVIII w. na pieczęciach większych. Nowe uprawnienia, a przez to i szczególna pozycja opata, zostały zamanifestowane poprzez uzyskanie pontyfikaliów, które również na stałe zagościły na pieczęciach opackich od pierwszej połowy XVI w. Pojawiły się najpierw na pieczęci mniejszej opata Andrzeja Hoffmanna, a następnie na pieczęci większej jego następcy, opata Jana V Franco. W tym samym czasie na pieczęciach opatów lubiąskich wprowadzano również herby. Na pieczęciach większych były one tylko jednym z elementów reprezentacji dostojnika. Opaci najpierw umieścili herb wskazujący na swój urząd, element ten z przerwami występował do schyłku XVIII w. Obok niego na początku XVII w. na pieczęci większej opata Mateusza Rudolfa pojawił się herb opactwa. Tego typu symbole na pieczęciach opaci umiejętnie wykorzystywali do podkreślenia swojego miejsca w klasztorze oraz w kontaktach ze światem zewnętrznym. Posługując się pieczęciami herbowymi, opat występował jako wyraziciel wspólnoty. Wskazywał przy tym na swoją istotną rolę. Herb opactwa stał się przez to po części jego własnym herbem, naprzemiennie wykorzystywanym z herbem urzędowym. Budując swoją pozycję w klasztorze, opaci wykorzystywali do tych celów także działalność fundatorską. Przykładowo za rządów wspomnianego opata Arnolda w XVII w. można dostrzec świadome wykorzystanie na tym polu herbów, w celu zaznaczenia szczególnego miejsca w klasztorze.

\section{Inwentarz pieczęci opatów lubiąskich (XV/XVI-XIX w.)}

W inwentarzu pieczęcie ułożono według ich właścicieli z uwzględnieniem chronologii lat ich urzędowania. W wyznaczonych $w$ ten sposób ramach pieczęcie danego opata zestawiono chronologicznie, zgodnie z ich funkcją kancelaryjną (większa, średnia i mniejsza) oraz typem wyobrażenia (piesza, herbowa). Nie udało się odnaleźć pieczęci opata Balthasara Nitschego (1692-1696). Z tego względu pominięto poświęconą mu notę inwentarzową. Opis każdej pieczęci rozpoczyna się numerem, po którym podano dane o właścicielu i daty jego urzędowania, poniżej umieszczono fotografię (ze względów technicznych zdecydowano się na publikację tylko wybranych reprodukcji pieczęci). W kolejnych pozycjach podano następujące informacje: 1) rodzaj pieczęci ${ }^{164}$ oraz typ, w porządku chronologicznym z podaniem kolejnej cyfry rzymskiej; wskazując także czas użycia pieczęci na podstawie znanych źródeł, zastosowano tutaj schemat wypracowany przez Piotra Pokorę ${ }^{165}$; 2) zachowany tłok; 3) wykaz zachowanych oryginalnych odcisków (gwiazdka oznacza egzemplarz, z którego wykonano fotografię);

\footnotetext{
${ }^{164}$ Na podstawie znanego mi materiału dyplomatycznego nie sposób dostrzec odrębnych funkcji pieczęci sekretnych. Z tych względów nie wydzielono ich z pieczęci mniejszych. Pełne zestawienie dokumentów opieczętowanych publikowanymi tutaj pieczęciami zostanie podane w planowanym inwentarzu pieczęci cystersów śląskich do $1810 \mathrm{r}$.

165 P. Pokora, Pieczęcie kapituly katedralnej gnieźnieńskiej, St. Źródł., 49, 2011, s. 1-59.
} 
4) wykaz kopii pieczęci; 5) edycja legendy ${ }^{166}$; 6) opis wyobrażenia napieczętnego; 7) kształt i wymiary tłoka albo odcisku (w mm); 8) sposób wykonania tłoka oraz jego odcisku; 9) formuła sigillacyjna ${ }^{167}$; 10) publikowane opisy i reprodukcje.

\section{Nr 1}

\section{Opat Andrzej Hoffmann z Krosna (1498-1534)}

1. Pieczęć większa, hagiograficzna, potwierdzona w użyciu w latach 1498-1532.

3. Or.: AP Wrocław, Rep. 91, nr 571, 583, 598, 600, 609, 633, 661, 681, 682; AP Wrocław, Oddział Legnica, Dokumenty miasta Legnicy, sygn. 647.

5. $+\mathrm{S}($ igillum $)+\operatorname{fr}($ atr $) \mathrm{iS}[\ldots]$ andre $(a) \mathrm{e} \& / \& *$ abbatiS $\bullet \mathrm{i}(n) \bullet \operatorname{lvbenS}$

Napis w otoku minuskułą z elementami majuskuły, w podwójnej obwódce ciągłej, przerywniki między wyrazami w formie krzyża złożonego z guzów, wici roślinnych i rozety okolonej guzami, linia pozioma nad ,i” w wyrazie fratris oraz nad „,i” w wyrazie in na oznaczenie skrótu.

6. W polu pieczęci opat (św. Bernard) w kukulli, z mucetem z kapturem na ramionach, stojący w kontrapoście na wsporniku w gotyckiej edykule baldachimowej, w prawej ręce trzyma pastorał o krzywaśni zwróconej na zewnątrz, z motywem kwiatonu w wolucie, w lewej zaś księgę, przestrzeń pod wspornikiem wypełnia ukośna kratownica, na niej głowa św. Jana Chrzciciela na misie, powyżej dwa ornamenty roślinne. Na zewnątrz pola pieczęci, po wewnętrznej i zewnętrznej stronie napisu, kilka obrzeżeń ciągłych.

7. Ostroowalna, $69 \times 45 \mathrm{~mm}$.

8. Odciski w wosku zielonym, w miskach z wosku naturalnego, przywieszone na paskach pergaminowych ( 2 z 1498); odcisk w wosku zielonym, w misce z wosku naturalnego, przywieszony na jasnym sznurze (1500); odciski w wosku czerwonym, w miskach z wosku naturalnego, przywieszone na paskach pergaminowych (2 z 1506, 1511, 1516, 1525, 2 z 1532).

9. Sub appensione sigilli mei abbacialis (1500) ${ }^{168}$; Zu mher sicherheit hab [en] wir dysen bryff mit unser eptey eyngesigel becrefftigen lossen (1506) ${ }^{169}$; Des zu urkunth und worer sicherheit haben wir das mit unsser eptey anhangenden ingesigel wyssentlich bestetigit (1511) ${ }^{170} ; \mathrm{Zu}$ mehrer sicherheyt haben wir im disen brieff mith unser eptey grossen insegill anhangende becrefftigen lossen (1525) $)^{171}$.

10. Opis: W.P. Könighaus, Die Zisterzienserabtei Leubus in Schlesien von ihrer Gründung bis zum Ende des 15. Jahrhunderts, Wiesbaden 2004, s. 374. Repr.: M.L. Wójcik, Heraldyka klasztorów cysterskich na Śląsku, w: Polska heraldyka kościelna. Stan i perspektywy badań, red. K. Skupieński, A. Weiss, Warszawa 2004, s. 48, fot. $1^{172}$.

166 Zapis legendy uwzględnia wymogi ujęte w Vocabularium internationale sigillographicum, red. K. Müller, L. Vrtel, M. Hlebionek, V. Keresztes, tł. na j. pol. B. Jusypenko, oprac. A. Baniecki, D. Bednarek, R. Forysiak-Wójciński, J. Grabowski, P. Gut, M. Hlebionek, P. Pokora, D. Żygadło, Bratislava 2016, s. 79-81. Rozwiązania skrótów podano minuskułą, kursywą, w nawiasach okrągłych, napisy zrekonstruowane umieszczono w nawiasach kwadratowych. Zachodzenie elementów wyobrażenia zaznaczono pojedynczym ukośnikiem /. Wprowadzono jednak kilka modyfikacji. Przerywniki między wyrazami oznaczono tylko uproszczonymi znakami graficznymi i opisano poniżej legendy, legendę również transkrybowano wielkimi bądź małymi literami, w zależności od formy liter wyrytych w legendzie.

$167 \mathrm{~W}$ pełnym brzmieniu przytoczono tylko te formuły, które odnoszą się bezpośrednio do pieczęci opatów lubiąskich. Dostarczają one bowiem najwięcej informacji dotyczących rodzaju pieczęci lub zaistnienia karencji danej pieczęci. Są one również wyłącznym wytworem kancelarii klasztornej, co nie występowało, jeśli opat był współwystawcą dokumentów z osobami lub instytucjami spoza klasztoru.

168 AP Wrocław, Rep. 91, nr 583.

169 Tamże, nr 598.

170 Tamże, nr 609.

171 Tamże, nr 661.

${ }^{172}$ Mylnie przyporządkowana poprzedniemu opatowi Bartłomiejowi II Lehnmanowi. 


\section{Nr 2}

\section{Opat Andrzej Hoffmann z Krosna (1498-1534)}

1. Pieczęć mniejsza (sekretna), piesza, potwierdzona w użyciu w $1521 \mathrm{r}$.

3. Or.: AP Wrocław, Rep. 84 nr 175.

5. : S(igillum) • ANDRE $(a) \mathrm{E} / \bullet:$ ABBBATIS :

Napis w otoku majuskułą na wstędze, przerywniki między wyrazami w formie pojedynczego guza oraz potrójnych guzów. 6. W polu pieczęci stojący frontalnie opat w kukulli, z mucetem $\mathrm{z}$ kapturem na ramionach, $\mathrm{w}$ infule na głowie, $\mathrm{z}$ pastorałem o krzywaśni zwróconej na zewnątrz w prawej ręce i księgą w lewej. Pastorał ma architektoniczny nodus, a jego krzywaśń ozdobiona jest żabkami na zewnętrznej krawędzi. Na zewnątrz pola pieczęci, po zewnętrznej stronie wstęgi z napisem, cien-

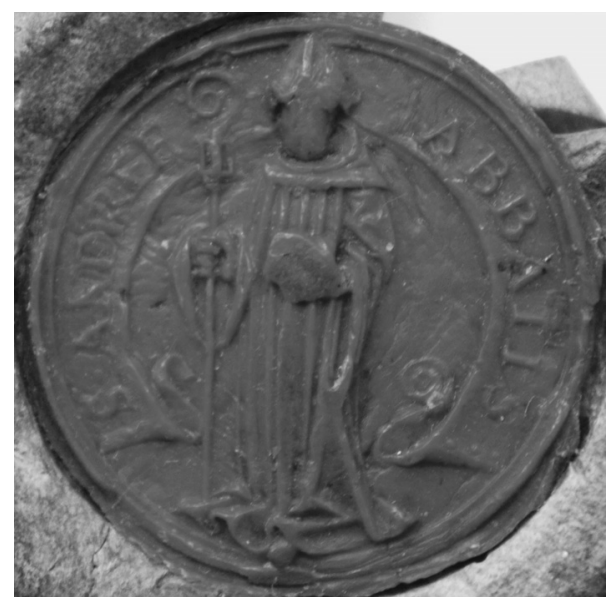
kie i grube obrzeżenie ciągłe.

7. Okrągła, ø $26 \mathrm{~mm}$.

8. Odcisk w wosku czerwonym, w misce $\mathrm{z}$ wosku naturalnego, przywieszony na pasku pergaminowym (1521).

9. nostro abbaciali sub secreto (1521).

\section{$\operatorname{Nr} 3$}

\section{Opat Jan V Franco (1534-1539)}

1. Pieczęć większa, piesza, potwierdzona w użyciu w latach 1536-[1539].

3. Or.: Národní archiv Praha, Archiv České koruny (1158-1935), sygn. 2014; dawniej także: AP Wrocław, Rep. 91, nr $710^{173}$.

5. - S (igillum) : FRATRIS • IOHANNIS • / • ABBATIS • LVBENSIS $\bullet \&$

Napis w otoku majuskułą na wstędze, przerywniki między wyrazami w formie pojedynczych guzów i podwójnego guza, legendę zamyka wić roślinna.

6. W polu pieczęci opat $\mathrm{w}$ kukulli, $\mathrm{z}$ mucetem $\mathrm{z}$ kapturem na ramionach, $\mathrm{w}$ infule $\mathrm{w}$ typie pretiosa na głowie, $\mathrm{z}$ pastorałem o krzywaśni zwróconej do wewnątrz w prawej ręce i księgą w lewej. Pastorał ma architektoniczny nodus, a jego krzywaśń ozdobiona jest żabkami na zewnętrznej krawędzi i fantazyjnie zagiętym wewnętrznym końcem woluty. Postać stoi na tle renesansowej edykuły o wysuniętych profilowanych cokołach, które podtrzymują dwukondygnacyjne pilastry o profilowanych płycinach i wydatnych gzymsowaniach. Na linii górnych gzym-

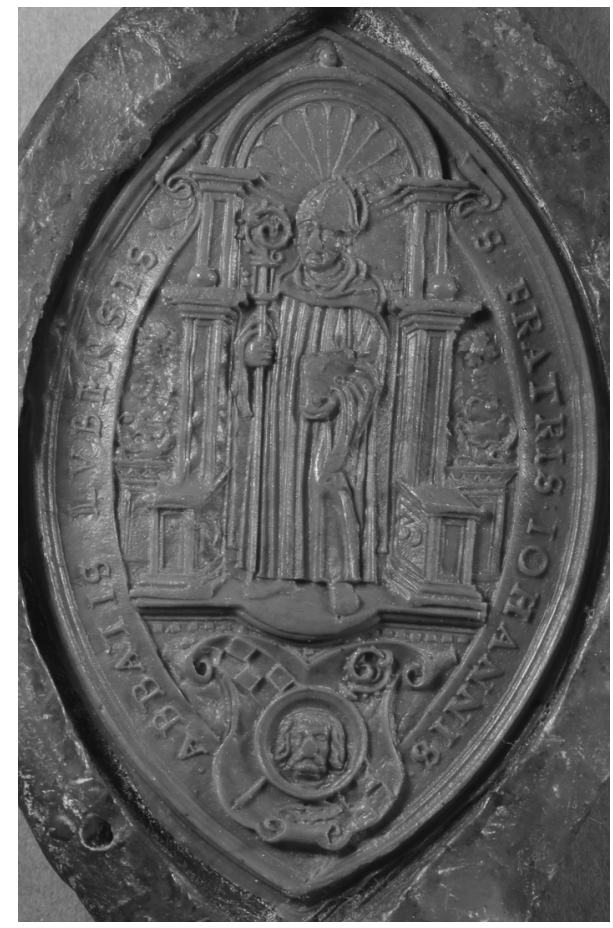
sowań zaznaczono ponadto perspektywicznie gzyms półkolistej wnęki zwieńczonej konchą. Po bokach edykuły widać wysunięte cokoły z datą 15/35 oraz ustawionymi na nich wazami z zatkniętymi kwiatami na długich łodygach. Poniżej edykuły herb urzędowy opata

${ }^{173} \mathrm{~W}$ formule sigillacyjnej dokumentu z 1539 r., przy którym nie zachowała się obecnie pieczęć, określono ją jako większą. Była to najpewniej publikowana tu pieczęć. 
(na tarczy szachowany dwurzędowy skos skrzyżowany z pastorałem, na nich głowa św. Jana Chrzciciela na misie). Na zewnątrz pola pieczęci, po zewnętrznej stronie wstęgi, cienkie i grube obrzeżenie ciągłe. 7. Ostroowalna, 67 x $43 \mathrm{~mm}$.

8. Odcisk w wosku czerwonym, w misce $\mathrm{z}$ wosku naturalnego, przywieszony na pasku pergaminowym (1536).

9. Formuła sigillacyjna nieznana ${ }^{174}$.

\section{Nr 4}

\section{Opat Jan V Franco (1534-1539)}

1. Pieczęć mniejsza, piesza, potwierdzona w użyciu w latach $1537-1538$.

3. Or.: AP Wrocław, Rep. 91, nr 703b*, 706; AP Wrocław, Oddział Legnica, Dokumenty miasta Jawora, sygn. 449, 450. 5. : S(igillum) $\bullet \mathrm{IO}(h)$ ANNIS $/ \bullet:$ ABBBATIS :

Napis $\mathrm{w}$ otoku majuskułą na wstędze, przerywniki między wyrazami w formie pojedynczego guza oraz potrójnych guzów. 6. W polu pieczęci stojący frontalnie opat $\mathrm{w}$ kukulli, $\mathrm{z}$ mucetem $\mathrm{z}$ kapturem na ramionach, $\mathrm{w}$ infule na głowie, $\mathrm{z}$ pastorałem o krzywaśni zwróconej na zewnątrz w prawej ręce i księgą w lewej. Pastorał ma architektoniczny nodus, a jego krzywaśń ozdobiona jest żabkami na zewnętrznej krawędzi. Na zewnątrz

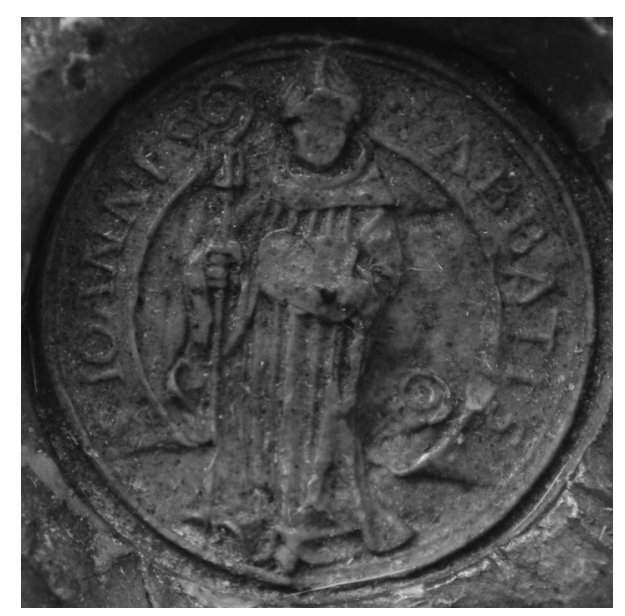
pola pieczęci, po zewnętrznej stronie wstęgi, cienkie i grube obrzeżenie ciągłe.

7. Okrągła, ø $26 \mathrm{~mm}$.

8. Odciski w wosku czerwonym, w miskach z wosku naturalnego, przywieszone na paskach pergaminowych $(1537,1538)$; odciski przez papier na podkładzie z wosku czerwonego ( 2 z 1537).

9. Des zu urkundt mit unserm auffgedrucktem ingesigell besygelt (1537) ${ }^{175}$; Dis zu urkunth mith auffgedrucktem unserm ingesiegel befestet (1537) ${ }^{176}$; In carencia pro tunc sygilli maioris contra sygillo nostro abbaciali subappenso $(1538)^{177}$.

\section{$\operatorname{Nr} 5$}

\section{Opat Jan VI Hiller (1539-1552)}

1. Pieczęć większa, piesza, potwierdzona w użyciu w latach 1543-1552.

3. Or.: AP Wrocław, Rep. 91, nr 722; AP Wrocław, Oddział Legnica, Dokumenty miasta Legnicy, sygn. $787,788,798,799$.

5. • S(igillum) : FRATRIS • IOHANNIS • $/$ ABBATIS $・$ LVBENSIS $\bullet \&$

Napis $\mathrm{w}$ otoku majuskułą na wstędze, przerywniki między wyrazami w formie pojedynczych guzów i podwójnego guza, legendę zamyka wić roślinna.

6. $\mathrm{W}$ polu pieczęci opat $\mathrm{w}$ kukulli, $\mathrm{z}$ mucetem $\mathrm{z}$ kapturem na ramionach, $\mathrm{w}$ infule $\mathrm{w}$ typie pretiosa na głowie, z pastorałem o krzywaśni zwróconej do wewnątrz w prawej ręce i księgą w lewej. Pastorał ma

\footnotetext{
${ }^{174}$ Formuła sigillacyjna dokumentu, przy którym zachowała się publikowana pieczęć, odnosi się do pieczęci opata i większej konwentu.

175 AP Wrocław, Oddział Legnica, Dokumenty miasta Jawora, sygn. 449.

176 Tamże, sygn. 450.

177 AP Wrocław, Rep. 91, nr 706.
} 
architektoniczny nodus, a jego krzywaśń ozdobiona jest żabkami na zewnętrznej krawędzi i fantazyjnie zagiętym wewnętrznym końcem woluty. Postać stoi na tle renesansowej edykuły o wysuniętych profilowanych cokołach, które podtrzymują dwukondygnacyjne pilastry o profilowanych płycinach i wydatnych gzymsowaniach. Na linii górnych gzymsowań zaznaczono ponadto perspektywicznie gzyms półkolistej wnęki zwieńczonej konchą. Po bokach edykuły widać wysunięte cokoły z datą 15/35 oraz ustawionymi na nich wazami z zatkniętymi kwiatami na długich łodygach. Poniżej edykuły herb urzędowy opata (na tarczy szachowany dwurzędowy skos skrzyżowany z pastorałem, na nich głowa św. Jana Chrzciciela na misie). Na zewnątrz pola pieczęci, po zewnętrznej stronie wstęgi, cienkie i podwójne grube obrzeżenie ciągłe.

7. Ostroowalna, $67 \times 45 \mathrm{~mm}$.

8. Odciski w wosku czerwonym, w miskach $\mathrm{z}$ wosku naturalnego, przywieszone na paskach pergaminowych (2 z 1543, 2 z 1545, 1552).

9. Zu welches uhrkundt wir umb willen stetter haltung und zu mehrer sicherheit unser der abbtey grosser ingesigel an disen brieff wissentlich hengen lassen (1543) ${ }^{178}$; Haben wir im namen dess stifftes alss der erpherre dess vilgemeldten guttes unser der eptey ingesiegel hiran gehangen (1545) ${ }^{179}$; Haben wir im namen dess styfftes als der erpherre dess vilgemeltte guttes unser der eptey ingesiegell hiran gehangen (1545) ${ }^{180} ; \mathrm{Zu}$ mehr sicherheit haben wir diesen brief mit unser ebtey angehengtem ingesiegel becreftiegen lossen (1552).

\section{Nr 6}

\section{Opat Jan VI Hiller (1539-1552)}

1. Pieczęć średnia (?) ${ }^{181}$, piesza, potwierdzona w użyciu w latach 1547-1549.

3. Or.: AP Wrocław, Rep. 3, nr 96*; Rep. 91, nr 719.

5. : S(igillum $) \cdot \mathrm{IO}(h)$ ANNIS $/ \bullet:$ ABBATIS :

Napis w otoku majuskułą na wstędze, przerywniki między wyrazami w formie pojedynczego guza oraz potrójnych guzów. 6. W polu pieczęci stojący frontalnie opat $\mathrm{w}$ kukulli, $\mathrm{z}$ mucetem $\mathrm{z}$ kapturem na ramionach, w infule na głowie, z pastorałem o krzywaśni zwróconej na zewnątrz w prawej ręce i księgą w lewej. Pastorał ma architektoniczny nodus, a jego krzywaśń ozdobiona jest żabkami na zewnętrznej krawędzi. Na zewnątrz pola pieczęci, po zewnętrznej stronie wstęgi, cienkie i grube

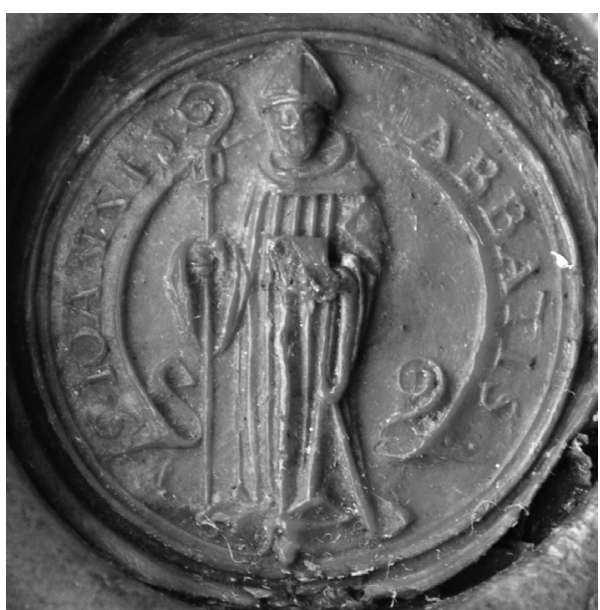
obrzeżenie ciągłe.

7. Okrągła, ø $26 \mathrm{~mm}$.

8. Odciski w wosku czerwonym, w miskach z wosku naturalnego, przywieszone na paskach pergaminowych $(1547,1549)$.

9. Formuła sigillacyjna nieznana ${ }^{182}$.

\footnotetext{
178 AP Wrocław, Oddział Legnica, Dokumenty miasta Legnicy, sygn. 788.

179 Tamże, sygn. 798.

180 Tamże, sygn. 799.

${ }^{181}$ Określiłem ją jako pieczęć średnią analogicznie do pieczęci z czasów rządów opata Mateusza Rudolfa w pierwszej połowie XVII w., gdyż wykazuje do niej podobieństwo pod względem rozmiaru, ikonografii i legendy. Określenie takie znajduje jednak pełne zastosowanie dopiero dla okresu po wykonaniu pieczęci mniejszej herbowej za rządów Jana VI. Wcześniej nie zachodziła potrzeba różnicowania pieczęci na mniejsze i średnie.

182 Formuły sigillacyjne dwóch dokumentów, przy których zachowały się odciski publikowanej pieczęci, odnoszą się zarówno do pieczęci opata, jak i miast Jawora oraz Legnicy.
} 


\section{Nr 7}

\section{Opat Jan VI Hiller (1539-1552)}

1. Pieczęć mniejsza, herbowa, potwierdzona w użyciu w latach 1540-1542.

3. Or.: AP Wrocław, Rep. 91, nr 712a, s. 2; nr 712b, 713.

5. I(ohannes) $\mathrm{A}($ bbas $) / \mathrm{I}(n) \mathrm{L}($ ubens $)$

Inicjały majuskułą w polu pieczęci ${ }^{183}$

6. W polu pieczęci herb urzędowy opata (na tarczy szachowany dwurzędowy skos, nad tarczą infuła, za nią pastorał), po obu stronach infuły i pastorału inicjały. Na zewnątrz pola pieczęci cienkie i grube obrzeżenie ciągłe.

7. Owalna, $21 \times 18 \mathrm{~mm}$.

8. Odciski przez papier na podkładzie z wosku czerwonego $(1540,1541)$; odcisk w wosku czerwonym, $\mathrm{w}$ misce z wosku naturalnego, przywieszony na pasku pergaminowym (1542).

9. nostro sub appenso sigillo $(1542)^{184}$.

10. Repr., opis: M.L. Wójcik, Heraldyka klasztorów cysterskich na Ślasku, w: Polska heraldyka kościelna. Stan i perspektywy badań, red. K. Skupieński, A. Weiss, Warszawa 2004, s. 48-49, fot. 4.

\section{Nr 8}

\section{Opat Jerzy z Legnicy (1552-1561)}

1. Pieczęć większa, [piesza], potwierdzona w użyciu [w 1560 r.].

3. Or.: nieznany.

8. Odcisk dawniej w wosku czerwonym, w misce $\mathrm{z}$ wosku naturalnego, przywieszony na pasku pergaminowym $(1560)^{185}$.

9. Dess zu urkhundt und mehrer beglaubigung [...] unser ebtey grossen ingesiegell [...] hengen $(1560)^{186}$.

\section{Nr 9}

\section{Opat Jerzy z Legnicy (1552-1561)}

1. Pieczęć mniejsza, herbowa, potwierdzona w użyciu w $1554 \mathrm{r}$.

3. Or.: AP Wrocław, Oddział Legnica, Dokumenty cechowe miasta Legnicy, sygn. 44.

5. $\mathrm{G}($ eorgius $) \mathrm{A}($ bbas $) / \mathrm{I}(n) \mathrm{L}($ ubens $)$

Inicjały majuskułą $\mathrm{w}$ polu pieczęci.

6. W polu pieczęci herb urzędowy opata (na tarczy szachowany dwurzędowy skos, nad tarczą infuła, za nią pastorał), po obu stronach infuły i pastorału inicjały. Na zewnątrz pola pieczęci cienkie i grube obrzeżenie ciągłe.

7. Owalna, $21 \times 18 \mathrm{~mm}$.

8. Odcisk przez papier na podkładzie z wosku czerwonego (1554).

9. Zue uhrkhunt mit unserer abbtey minor ingesiegel vorsieglett

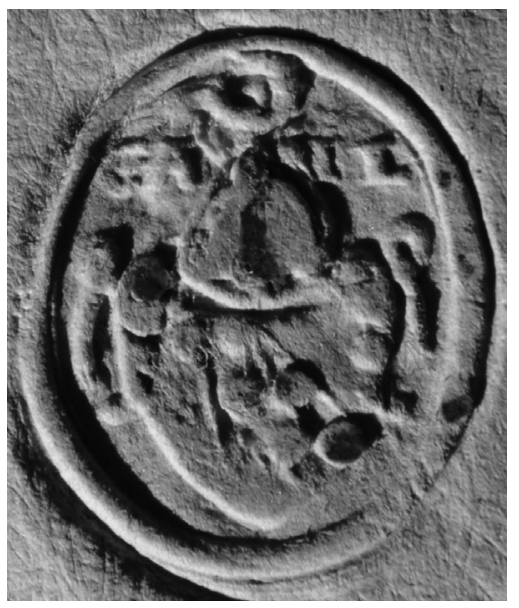
$(1554)^{187}$.

\footnotetext{
183 Próba rekonstrukcji legendy na podstawie intytulacji dokumentów dysponenta tłoka.

184 AP Wrocław, Rep. 91, nr 713.

185 Informacja za opisem umieszczonym w inwentarzu archiwalnym; zob. tamże, nr 729.

186 Tamże.

187 AP Wrocław, Oddział Legnica, Dokumenty cechowe miasta Legnicy, sygn. 44.
} 


\section{Nr 10}

\section{Opat Jan VII Bock/Franco (1562-1568)}

1. Pieczęć większa, piesza, potwierdzona w użyciu w latach $1565-1566$.

3. Or.: AP Wrocław, Rep. 91, nr 737*, 738.

5. [•] S(igillum) : FRATRIS $\bullet \mathrm{IOH}[\mathrm{AN}(n)] \mathrm{IS} \bullet /[\bullet \mathrm{AB}] \mathrm{BATIS}$

$\cdot$ LVBENSIS • \&

Napis w otoku majuskułą na wstędze, przerywniki między wyrazami w formie pojedynczych guzów i podwójnego guza, legendę zamyka wić roślinna.

6. W polu pieczęci opat w kukulli, z mucetem z kapturem na ramionach, $\mathrm{w}$ infule $\mathrm{w}$ typie pretiosa na głowie, $\mathrm{z}$ pastorałem o krzywaśni zwróconej do wewnątrz w prawej ręce i księgą w lewej. Pastorał ma architektoniczny nodus, a jego krzywaśń ozdobiona jest żabkami na zewnętrznej krawędzi i fantazyjnie zagiętym wewnętrznym końcem woluty. Postać stoi na tle renesansowej edykuły o wysuniętych profilowanych cokołach, które podtrzymują dwukondygnacyjne pilastry o profilowanych płycinach i wydatnych gzymsowaniach. Na linii górnych gzymsowań zaznaczono ponadto perspektywicznie gzyms półkolistej wnęki zwieńczonej konchą. Po bokach

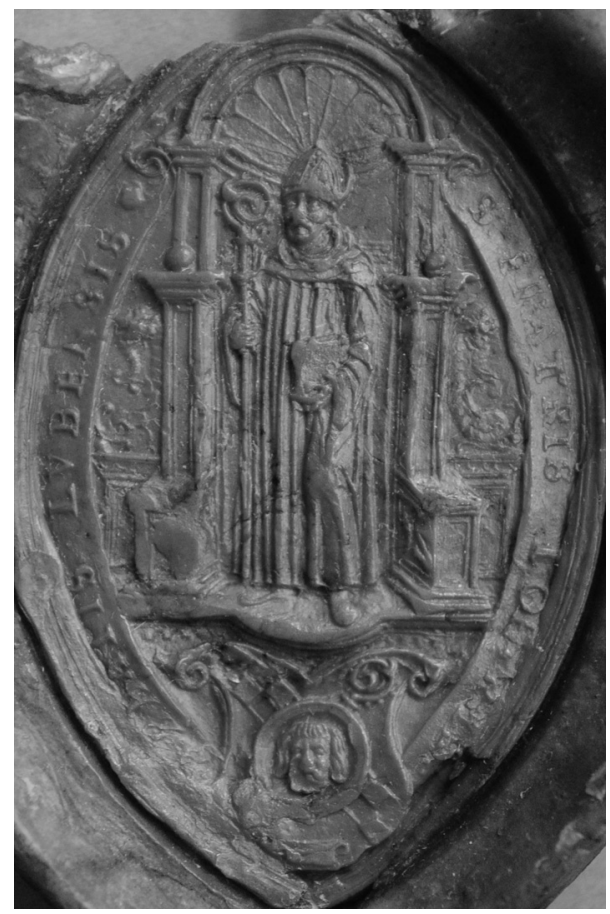
edykuły widać wysunięte cokoły z częściowo zachowaną datą [1]5/52 (cyfra „2” w lustrzanym odbiciu) oraz ustawionymi na nich wazami z zatkniętymi kwiatami na długich łodygach. Poniżej edykuły herb urzędowy opata (na tarczy szachowany dwurzędowy skos skrzyżowany z pastorałem, na nich głowa św. Jana Chrzciciela na misie). Na zewnątrz pola pieczęci, po zewnętrznej stronie wstęgi, cienkie i podwójne grube obrzeżenie ciągłe.

7. Ostroowalna, $67 \times 44 \mathrm{~mm}$.

8. Odciski w wosku czerwonym, w miskach z wosku naturalnego, przywieszone na paskach pergaminowych $(1565,1566)$.

9. Dess zu urkhundt mit unserem abtei grosserem anhangenden insiegell bekrefftigkeitt (1565) ${ }^{188}$; Dess zu urkhundt und mehrer beglaubigung haben wir unser abtey grosser ingesiegel hiran hengen lassen $(1566)^{189}$.

\section{Nr 11}

\section{Opat Jan VIII Klein (1568-1584)}

1. Pieczęć większa, piesza, potwierdzona w użyciu w latach 1571-1581.

3. Or.: AP Wrocław, Rep. 83, nr 384, 392 ${ }^{190}$; Rep. 91, nr 749.

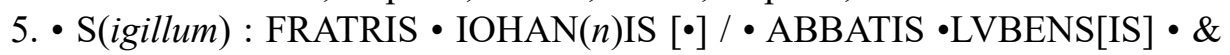

Napis w otoku majuskułą na wstędze, pozioma linia na oznaczenie kontrakcji w wyrazie „IOHAN(n)IS”, przerywniki między wyrazami w formie pojedynczych guzów i podwójnego guza, legendę zamyka wić roślinna.

\footnotetext{
188 AP Wrocław, Rep. 91, nr 737.

189 Tamże, nr 738.

190 Przesunięcie tłoka przy wykonywaniu tego odcisku spowodowało zniekształcenie jednego z wyrazów końcowej części legendy, który zachował się w formie AABBBATTS. Na innych egzemplarzach tej pieczęci legenda w tym miejscu uległa zniszczeniu.
} 
6. W polu pieczęci opat $\mathrm{w}$ kukulli, $\mathrm{z}$ mucetem $\mathrm{z}$ kapturem na ramionach, $\mathrm{w}$ infule $\mathrm{w}$ typie pretiosa na głowie, z pastorałem o krzywaśni zwróconej do wewnątrz w prawej ręce i księgą w lewej. Pastorał ma architektoniczny nodus, a jego krzywaśń ozdobiona jest żabkami na zewnętrznej krawędzi i fantazyjnie zagiętym wewnętrznym końcem woluty. Postać stoi na tle renesansowej edykuły o wysuniętych profilowanych cokołach, które podtrzymują dwukondygnacyjne pilastry o profilowanych płycinach i wydatnych gzymsowaniach. Na linii górnych gzymsowań zaznaczono ponadto perspektywicznie gzyms półkolistej wnęki zwieńczonej konchą. Po bokach edykuły widać wysunięte cokoły z datą 15/52 (cyfra „2” w lustrzanym odbiciu) oraz ustawionymi na nich wazami z zatkniętymi kwiatami na długich łodygach. Poniżej edykuły herb urzędowy opata (na tarczy szachowany dwurzędowy skos skrzyżowany z pastorałem, na nich głowa św. Jana Chrzciciela na misie). Na zewnątrz pola pieczęci, po zewnętrznej stronie wstęgi, cienkie i podwójne grube obrzeżenie ciągłe.

7. Ostroowalna, $70 \times 44,5 \mathrm{~mm}$.

8. Odciski w wosku czerwonym, w miskach z wosku naturalnego, przywieszone na paskach pergaminowych $(1571,1579,1581)$.

9. Dessen zue urkundt haben wir unser abtey grösser insiegel wiesentlich hieran hengen lassen $(1571)^{191}$; Des zue uhrkundt und mehr [...] grosser insiegel [...] hangen lassen $(1581)^{192}$.

\section{Nr 12}

\section{Opat Jan VIII Klein (1568-1584)}

1. Pieczęć średnia (?) ${ }^{193}$, piesza, potwierdzona w użyciu w 1582 r.

3. Or.: AP Wrocław, Rep. 91, $\mathrm{nr} 753^{194}$.

5. [: S(igillum) •] IOHAN(n)IS $/ \bullet:$ ABBATIS [:]

Napis w otoku majuskułą na wstędze, przerywniki między wyrazami w formie pojedynczego guza oraz potrójnych guzów.

6. W polu pieczęci stojący frontalnie opat $\mathrm{w}$ kukulli, $\mathrm{z}$ mucetem $\mathrm{z}$ kapturem na ramionach, $\mathrm{w}$ infule na głowie, z pastorałem o krzywaśni zwróconej na zewnątrz w prawej ręce i księgą w lewej. Pastorał ma architektoniczny nodus, a jego krzywaśń ozdobiona jest żabkami na zewnętrznej krawędzi. Na zewnątrz pola pieczęci, po zewnętrznej stronie wstęgi, cienkie i grube obrzeżenie ciągłe.

7. Okrągła, ø $27 \mathrm{~mm}$.

8. Odcisk w wosku czerwonym, w misce $\mathrm{z}$ wosku naturalnego, przywieszony na pasku pergaminowym (1582).

9. Formuła sigillacyjna nieznana ${ }^{195}$.

\section{Nr 13}

\section{Opat Jan VIII Klein (1568-1584)}

1. Pieczęć mniejsza (sekretna), herbowa, potwierdzona w użyciu w 1569 r.

3. Or.: AP Wrocław, Oddział Legnica, Dokumenty cechowe miasta Legnicy, sygn. 56.

5. I(ohannes) A(bbas) / L(ubensis)

Inicjały majuskułą $\mathrm{w}$ polu pieczęci.

191 AP Wrocław, Rep. 83, nr 384.

192 Tamże, Rep. 91, nr 749.

193 Zob. komentarz: Inwentarz, nr 6.

194 Przesunięcie tłoka przy wykonywaniu odcisku spowodowało zniekształcenie końcowej części legendy, która zachowała się w formie ABBBATIS.

${ }^{195}$ Formuła sigillacyjna dokumentu, przy którym zachowała się publikowana pieczęć, odnosi się do pieczęci opata i średniej konwentu. 
6. W polu pieczęci herb urzędowy opata (na tarczy szachowany dwurzędowy skos, na nim głowa św. Jana Chrzciciela na misie, nad tarczą infuła, za nią pastorał), po obu stronach infuły i pastorału inicjały. Na zewnątrz pola pieczęci cienkie ciągłe i grube wieńcowe (?).

7. Owalna, 17 x $15 \mathrm{~mm}$.

8. Odcisk przez papier na podkładzie z wosku czerwonego (1569).

9. Zu urkhundt undt mehrer beglaubigung haben wir unser ebtei secrech wissentlich hierauff drucken lassen (1569).

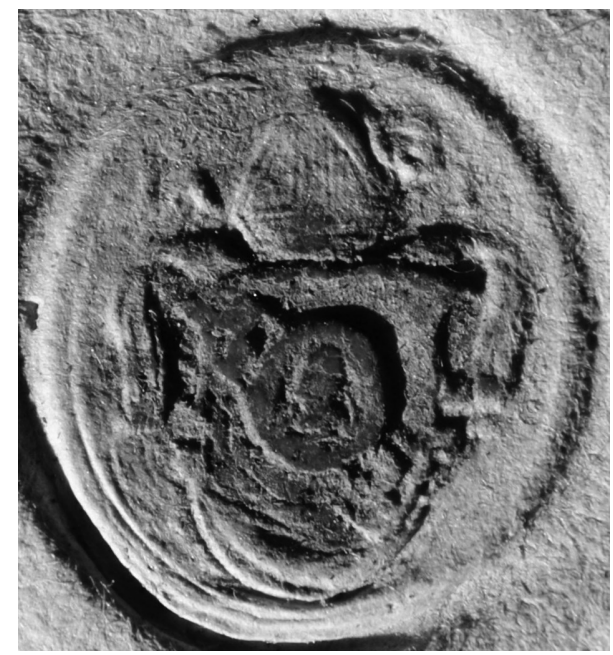

\section{Nr 14}

\section{Opat Hieronim Nikodem (1584-1594)}

1. Pieczęć większa, piesza, potwierdzona w użyciu w 1587 r.

3. Or.: AP Wrocław, Rep. 91, nr 759b.

\section{5. $\bullet$ S $($ igillum $)$ : FRATRIS $\left[\bullet\right.$ HIER $[\mathrm{ONIM}]$ I $/ \bullet$ ABBBATIS $[\bullet \text { LV]B[ENSIS } \bullet \&]^{196}$}

Napis $\mathrm{w}$ otoku majuskułą na wstędze, przerywniki między wyrazami $\mathrm{w}$ formie pojedynczych guzów i podwójnego guza.

6. W polu pieczęci opat $\mathrm{w}$ kukulli, $\mathrm{z}$ mucetem $\mathrm{z}$ kapturem na ramionach, $\mathrm{w}$ infule $\mathrm{w}$ typie pretiosa na głowie, z pastorałem o krzywaśni zwróconej do wewnątrz w prawej ręce i księgą w lewej. Pastorał ma architektoniczny nodus, a jego krzywaśń ozdobiona jest żabkami na zewnętrznej krawędzi i fantazyjnie zagiętym wewnętrznym końcem woluty. Postać stoi na tle renesansowej edykuły o wysuniętych profilowanych cokołach, które podtrzymują dwukondygnacyjne pilastry o profilowanych płycinach i wydatnych gzymsowaniach. Na linii górnych gzymsowań zaznaczono ponadto perspektywicznie gzyms półkolistej wnęki zwieńczonej konchą. Po bokach edykuły widać wysunięte cokoły z częściowo zachowaną datą $15 / 5$ [2] oraz ustawionymi na nich wazami z zatkniętymi kwiatami na długich łodygach. Poniżej edykuły umieszczono herb urzędowy opata (na tarczy szachowany dwurzędowy skos skrzyżowany z pastorałem, na nich głowa św. Jana Chrzciciela na misie). Na zewnątrz pola pieczęci, po zewnętrznej stronie wstęgi, cienkie i podwójne grube obrzeżenie ciągłe.

7. Ostroowalna, 70 x $45 \mathrm{~mm}$.

8. Odcisk w wosku czerwonym, w misce $\mathrm{z}$ wosku naturalnego, przywieszony na pasku pergaminowym (1587).

9. Formuła sigillacyjna nieznana ${ }^{197}$.

\section{Nr 15}

\section{Opat Hieronim Nikodem (1584-1594)}

1. Pieczęć mniejsza (sekretna), herbowa, potwierdzona w użyciu w 1584 r.

3. Or.: AP Wrocław, Rep. 91, nr 756, s. 2.

5. $\mathrm{H}($ ieronimus $) /[\mathrm{A}($ bbas $) \mathrm{L}($ ubensis $)]$

Inicjały majuskułą w polu pieczęci.

196 Przesunięcie tłoka przy wykonywaniu odcisku spowodowało zniekształcenie końcowej części legendy.

${ }^{197}$ Formuła sigillacyjna dokumentu, przy którym zachowała się publikowana pieczęć, odnosi się do pieczęci opata i większej konwentu. 
6. W polu pieczęci herb urzędowy opata (na tarczy szachowany dwurzędowy skos, na nim głowa św. Jana Chrzciciela na misie, nad tarczą infuła, za nią pastorał [?]), po obu stronach infuły i pastorału (?) inicjały. Na zewnątrz pola pieczęci grube obrzeżenie wieńcowe (?) ${ }^{198}$.

7. Okrągła, ø $18 \mathrm{~mm}$.

8. Odcisk przez papier na podkładzie z wosku czerwonego (1584).

9. Zue uhrkundtt mit unseren abbtei hierauf gedrucktten secrett bekrefftigett (1584).

\section{Nr 16}

\section{Opat Franciszek I Ursinus (1594-1607)}

1. Pieczęć większa, piesza, potwierdzona w użyciu w latach 1602-1605.

3. Or.: AP Wrocław, Rep. 91, nr 773; AP Wrocław, Oddział Legnica, Dokumenty miasta Legnicy, sygn. 899.

5. $・$ S(igillum $):$ FRATRIS $・$ FRANCISCV[S] $\bullet / ・$ ABBATIS $*$ LVBENSIS $\bullet \&$

Napis w otoku majuskułą na wstędze, przerywniki między wyrazami w formie pojedynczych guzów i podwójnego guza, legendę zamyka wić roślinna.

6. $\mathrm{W}$ polu pieczęci opat $\mathrm{w}$ kukulli, $\mathrm{z}$ mucetem $\mathrm{z}$ kapturem na ramionach, $\mathrm{w}$ infule $\mathrm{w}$ typie pretiosa na głowie, z pastorałem o krzywaśni zwróconej do wewnątrz w prawej ręce i księgą w lewej. Pastorał ma architektoniczny nodus, a jego krzywaśń ozdobiona jest żabkami na zewnętrznej krawędzi i fantazyjnie zagiętym wewnętrznym końcem woluty. Postać stoi na tle renesansowej edykuły o wysuniętych profilowanych cokołach, które podtrzymują dwukondygnacyjne pilastry o profilowanych płycinach i wydatnych gzymsowaniach. Na linii górnych gzymsowań zaznaczono ponadto perspektywicznie gzyms półkolistej wnęki zwieńczonej konchą. Po bokach edykuły widać wysunięte cokoły z częściowo zachowaną datą 15/5[2] oraz ustawionymi na nich wazami z zatkniętymi kwiatami na długich łodygach. Poniżej edykuły herb urzędowy opata (na tarczy szachowany dwurzędowy skos skrzyżowany z pastorałem, na nich głowa św. Jana Chrzciciela na misie). Na zewnątrz pola pieczęci, po zewnętrznej stronie wstęgi, cienkie i podwójne grube obrzeżenie ciągłe.

7. Ostroowalna, 69 x $45 \mathrm{~mm}$.

8. Odciski w wosku czerwonym, w miskach z wosku naturalnego, przywieszone na paskach pergaminowych $(1602,1605)$.

9. Formuła sigillacyjna nieznana ${ }^{199}$.

\section{Nr 17}

\section{Opat Franciszek I Ursinus (1594-1607)}

1. Pieczęć mniejsza I, herbowa, potwierdzona w użyciu w 1595 r.

3. Or.: AP Wrocław, Rep. 33, nr 125, k. 2.

5. $\mathrm{F}$ (ranciscus) $\mathrm{A}($ bbas $) / \mathrm{L}($ ubensis $)$

Inicjały majuskułą $\mathrm{w}$ polu pieczęci.

6. W polu pieczęci herb urzędowy opata (na tarczy w kartuszu szachowany dwurzędowy skos, na nim głowa św. Jana Chrzciciela na misie, nad kartuszem infuła, za nią pastorał), po obu stronach infuły i pastorału inicjały. Na zewnątrz pola pieczęci obrzeżenie grube ciągłe.

7. Owalna, $18 \times 16 \mathrm{~mm}$.

8. Odcisk przez papier na podkładzie z wosku czerwonego (1595).

9. Formuła sigillacyjna nieznana.

\footnotetext{
198 Analizę wyobrażenia utrudnia znaczne zagniecenie pieczęci.

199 Formuły sigillacyjne dwóch dokumentów, przy których zachowała się publikowana pieczęć, odnoszą się do pieczęci opata i większej konwentu.
} 


\section{Nr 18}

\section{Opat Franciszek I Ursinus (1594-1607)}

1. Pieczęć mniejsza II, herbowa, potwierdzona w użyciu w 1598 r.

3. Or.: AP Wrocław, Rep. 24, nr 610, s. 60.

5. $[\mathrm{F}($ ranciscus $)] \mathrm{A}($ bbas $) /[\mathrm{L}($ ubensis $)]$

Inicjały majuskułą $\mathrm{w}$ polu pieczęci ${ }^{200}$.

6. W polu pieczęci herb urzędowy opata (na tarczy szachowany dwurzędowy skos, na nim głowa św. Jana Chrzciciela na misie, nad tarczą infuła, za nią pastorał), po obu stronach infuły i pastorału inicjały. Na zewnątrz pola pieczęci obrzeżenie (?).

7. Okrągła (?), ok. ø $20 \mathrm{~mm}$.

8. Odcisk dawniej przez papier na podkładzie z wosku czerwonego (1598).

9. Formuła sigillacyjna nieznana.

\section{Nr 19}

\section{Opat Mateusz Rudolf (1607-1636)}

1. Pieczęć większa, piesza, potwierdzona w użyciu w 1635 r. 3. Or.: AA Wrocław, Dokumenty klasztoru w Henrykowie, nr 203*-204 (2 IV 1635).

5. \& - S(igillum) : FRAT(ris) MATTHAEI RV/DOLPHI • ABBATIS $•$ LVBENS $(i s): \&$

Napis w otoku majuskułą na wstędze, litery „A” $\mathrm{i}$,E” w ligaturze, przerywniki między wyrazami w formie pojedynczych i podwójnych guzów, legendę rozpoczynają i zamykają wici roślinne.

6. $\mathrm{W}$ polu pieczęci opat $\mathrm{w}$ kukulli, $\mathrm{z}$ mucetem na ramionach, $\mathrm{w}$ infule $\mathrm{w}$ typie pretiosa na głowie, z pastorałem o krzywaśni zwróconej na zewnątrz w prawej ręce i księgą w lewej. Nodus pastorału w formie trzech kul nierównej wielkości, krzywaśń ozdobiona żabkami na zewnętrznej krawędzi i motywem kuli w wolucie, poniżej środkowej kuli zawieszony jest panniselus. Opat stoi w renesansowej arkadzie, ustawionej na niewysokim postumencie, z kolumnami na profilowanych cokołach, trzonach

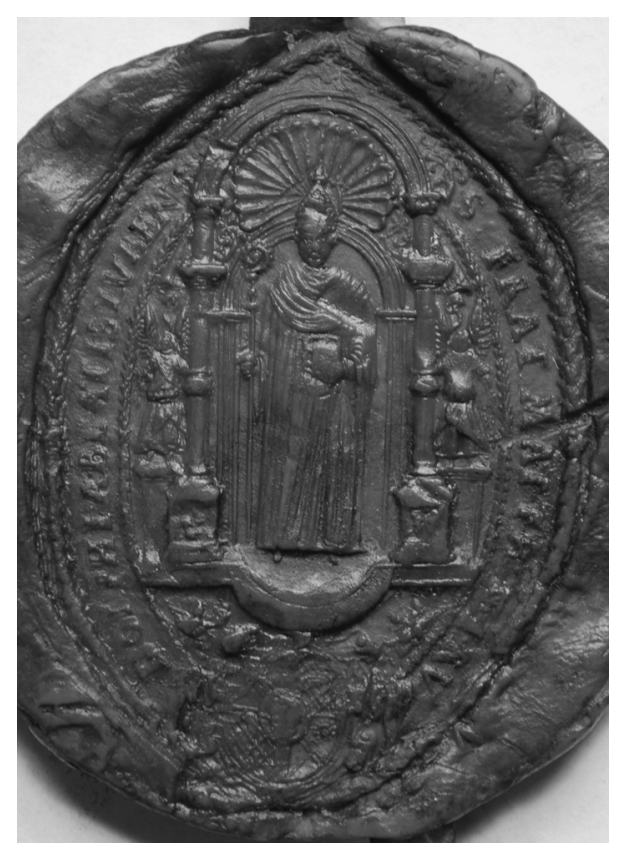
z przewiązkami i podwójnymi kapitelami, nad którymi wznosi się profilowany łuk. W tle stojącego opata zaznacza się mniejsza edykuła (lub portal) zwieńczona konchą. Po bokach widać wysunięte cokoły, na których ustawiono dwa anioły w tunikach. Poniżej arkady herb opactwa (na tarczy w kartuszu dzielonej w krzyż, pośrodku głowa św. Jana Chrzciciela na misie, w polu drugim i piątym szachowany dwurzędowy skos skrzyżowany z pastorałem, w polu trzecim i czwartym wspięty lew za kratą). Po wewnętrznej i zewnętrznej stronie wstęgi z napisem grube obrzeżenie wieńcowe.

7. Ostroowalna, $71 \times 50 \mathrm{~mm}$.

8. Odcisk w wosku czerwonym (dawniej w puszcze drewnianej) przywieszony na pasku pergaminowym (1635); odcisk przez papier na podkładzie z wosku czerwonego (1635).

9. Formuła sigillacyjna nieznana ${ }^{201}$.

200 Analizę legendy i wyobrażenia utrudnia znaczne uszkodzenie pieczęci (zagniecenie i brak custodium).

${ }^{201}$ Formuła sigillacyjna dokumentów, przy których zachowała się publikowana pieczęć, odnosi się do pieczęci opata lubiąskiego, kamienieckiego i konwentu henrykowskiego. 


\section{Nr 20}

\section{Opat Mateusz Rudolf (1607-1636)}

1. Pieczęć średnia ${ }^{202}$, piesza, potwierdzona w użyciu w latach $1620-1630$.

3. Or.: AP Wrocław, Rep. 91, nr 817; AP Wrocław, Oddział Legnica, Dokumenty miasta Legnicy, sygn. 914*.

5. MATTHAEVS / ABBBAS LVBENSIS

Napis w otoku majuskułą na wstędze, litery „A" i „E” w ligaturze w wyrazie „MATTHAEVS”.

6. W polu pieczęci stojący frontalnie opat $\mathrm{w}$ kukulli, $\mathrm{z}$ mucetem $\mathrm{z}$ kapturem na ramionach, $\mathrm{w}$ infule na głowie, $\mathrm{z}$ pastorałem o krzywaśni zwróconej do wewnątrz w prawej ręce i księgą w lewej. Pastorał ma architektoniczny nodus, a jego krzywaśń ozdobiona jest żabkami na zewnętrznej krawędzi i motywem

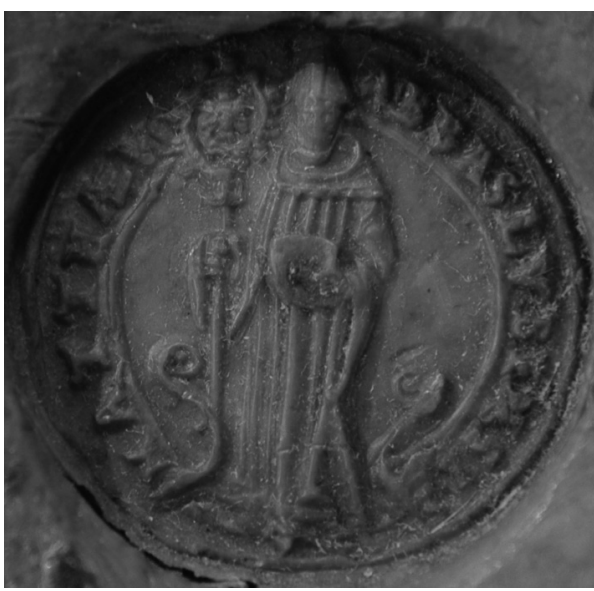
kwiatonu w wolucie. Na zewnątrz pola pieczęci, po zewnętrznej stronie wstęgi z napisem, grube obrzeżenie ciągłe.

7. Okrągła, ø $27 \mathrm{~mm}$.

8. Odciski w wosku czerwonym, w miskach $\mathrm{z}$ wosku naturalnego, przywieszone na paskach pergaminowych $(1620,1630)$.

9. Formuła sigillacyjna nieznana ${ }^{203}$.

\section{Nr 21}

\section{Opat Mateusz Rudolf (1607-1636)}

1. Pieczęć mniejsza (sekretna ${ }^{204}$ ) I, herbowa, potwierdzona w użyciu w latach $1608-1630$.

3. Or.: AP Wrocław, Rep. 33, nr 342, k. 2; Rep. 91, nr 782b, s. 2 ; nr 788 , s. 3 ; nr 802 , s. 3 ; nr 809 , s. 2 ; nr 811 , s. $2^{*}$; nr 824 , s. 7 ; nr 826 , s. 9 ; nr 827 , s. 6 ; nr 831 , s. 11 ; nr 850 , s. 3.

5. MATTHAVS $\bullet 16 \bullet / 07 / \bullet$ ABBAS LVBENSIS

Napis w otoku majuskułą $\mathrm{w}$ otoku, w podwójnej obwódce perełkowej, przerywniki między wyrazami w formie pojedynczych guzów.

6. W polu pieczęci herb urzędowy opata (na tarczy w kartuszu szachowany dwurzędowy skos, na nim głowa św. Jana Chrzciciela na misie, nad kartuszem infuła, za nią pastorał o krzywaśni skierowanej na zewnątrz, z żabkami na jego zewnętrznej krawędzi). Na zewnątrz pola pieczęci, po zewnętrznej stronie napisu, grube obrzeżenie wieńcowe.

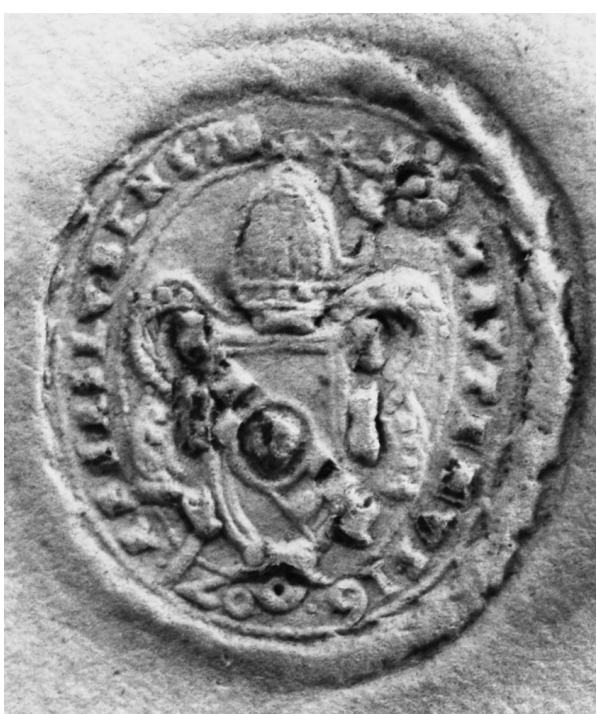

7. Owalna, $26 \times 22 \mathrm{~mm}$.

8. Odciski przez papier na podkładzie z wosku czerwonego $(1608,1613,2$ z 1616, 1617, 1618, 2 z 1621, 2 z 1622, 1630).

${ }^{202}$ Określenie w dokumencie z 1620 r.; zob. AP Wrocław, Rep. 91, nr 817.

${ }^{203}$ Formuły sigillacyjne dwóch dokumentów, przy których zachowały się egzemplarze publikowanej pieczęci, odnoszą się do pieczęci średniej opata i innych współpieczętujących.

204 Określenie występuje w formule sigillacyjnej dokumentu z 1622 r., która odnosi się do pieczęci opata i szlachty (AP Wrocław, Rep. 91, nr 831, s. 11), a także w formule koroboracyjnej dokumentu wystawionego przez opata w 1621 r., która odnosi się do jego podpisu i pieczęci (tamże, nr 826, s. 9). 
9. Zu mehrer sicherheit mit unserem der abbtei insigel verfertigt $(1608)^{205}$; Dessen zue glaubwürdigenschein undt uhrkhundt haben wür unser der abtey insiegell wissenttlich hiefür druekhen lassen (1618) ${ }^{206}$; Zue mehrer beglaubigung alles dessen was obstehet haben wier hierauf unser der abbtey insiegel wissendtlich drucken lassen $(1621)^{207}$.

\section{Nr 22}

\section{Opat Mateusz Rudolf (1607-1636)}

1. Pieczęć mniejsza II, herbowa, potwierdzona w użyciu w $1611 \mathrm{r}$.

3. Or.: AP Wrocław, Rep. 67, nr 2291, s. 4.

5. Inicjały w polu pieczęci nieczytelne.

6. W polu pieczęci herb urzędowy opata (na tarczy w kartuszu szachowany dwurzędowy skos, na nim głowa św. Jana Chrzciciela na misie, nad kartuszem infuła, za nią pastorał), po obu stronach infuły i pastorału inicjały. Na zewnątrz pola pieczęci grube obrzeżenie ciągłe.

7. Ośmioboczny, 17 x $15 \mathrm{~mm}$.

8. Odcisk przez papier na podkładzie z wosku czerwonego (1611).

9. Formuła sigillacyjna nieznana ${ }^{208}$.

\section{Nr 23}

\section{Opat Arnold Freiberger (1636-1672)}

1. Pieczęć większa, piesza, potwierdzona w użyciu w latach 1645-1656.

3. Or.: AA Wrocław, Dokumenty klasztoru w Henrykowie, nr 212 (21 X 1656); AP Wrocław, Rep. 85, nr 58, 64; Rep. 91, nr 865, s. 4.

5. \& SIGIL(lum) [*] FRATR(is) [*] AR/NOLDI • ABBATIS • LVBENS(is) [:] \&

Napis w otoku majuskułą na wstędze, przerywniki między wyrazami w formie podwójnych rozet (?) i pojedynczych guzów, legendę rozpoczynają i zamykają wici roślinne.

6. W polu pieczęci opat w kukulli, $\mathrm{z}$ mucetem na ramionach, $\mathrm{w}$ infule $\mathrm{w}$ typie pretiosa na głowie, $\mathrm{z}$ pastorałem o krzywaśni zwróconej na zewnątrz w prawej ręce i księgą w lewej. Nodus pastorału w formie trzech kul nierównej wielkości, krzywaśń ozdobiona żabkami na zewnętrznej krawędzi i motywem kuli w wolucie, poniżej środkowej kuli zawieszony jest panniselus. Opat stoi w renesansowej arkadzie, ustawionej na niewysokim postumencie, z kolumnami na profilowanych cokołach, trzonach z przewiązkami i podwójnymi kapitelami, nad którymi wznosi się profilowany łuk. W tle stojącego opata zaznacza się mniejsza edykuła (lub portal) zwieńczona konchą. Po bokach widać wysunięte cokoły, na których ustawiono dwa anioły w tunikach. Poniżej arkady herb opactwa (na tarczy w kartuszu dzielonej w krzyż, pośrodku głowa św. Jana Chrzciciela na misie, w polu drugim i piątym szachowany dwurzędowy skos skrzyżowany z pastorałem, w polu trzecim i czwartym wspięty lew za kratą). Po wewnętrznej i zewnętrznej stronie wstęgi z napisem grube obrzeżenie wieńcowe.

7. Ostroowalna, 74 x $50 \mathrm{~mm}$

8. Odciski w wosku czerwonym w puszkach metalowych bez wieczek przywieszone na paskach pergaminowych $(1645,1656)$; odcisk w wosku czerwonym w puszce metalowej bez wieczka, przywieszony na sznurach biało-czarnych (po 1648); odcisk przez papier na podkładzie z wosku czerwonego (1651).

205 Tamże, nr 782b, s. 2.

206 Tamże, nr 811, s. 2.

207 Tamże, nr 824, s. 7.

${ }^{208}$ Formuła sigillacyjna dokumentu, na którym zachowała się publikowana pieczęć, oprócz niej odnosi się do pieczęci biskupa pomocniczego diecezji wrocławskiej i zarazem opata premonstratensów klasztoru św. Wincentego we Wrocławiu, opata klasztoru kanoników regularnych NMP na Piasku oraz w Żaganiu, opatów klasztorów cysterskich w Henrykowie, Kamieńcu i Krzeszowie, a także ksieni opactw cysterek w Trzebnicy i klarysek we Wrocławiu. 
9. Formuła sigillacyjna nieznana ${ }^{209}$.

10. Repr.: M.L. Wójcik, Heraldyka klasztorów cysterskich na Śląsku, w: Polska heraldyka kościelna. Stan i perspektywy badań, red. K. Skupieński, A. Weiss, Warszawa 2004, s. 52, fot. 9.

\section{Nr 24}

\section{Opat Arnold Freiberger (1636-1672)}

1. Pieczęć mniejsza I, herbowa, potwierdzona w użyciu w $1638 \mathrm{r}$.

3. Or.: AP Wrocław, Rep. 91, nr 858, s. 3*.

5. $\mathrm{A}($ rnoldus $)[\bullet] \mathrm{A}($ bbas $) \cdot \mathrm{L}($ ubensis $)$

Inicjały majuskułą w polu pieczęci, przerywnik między wyrazami $\mathrm{w}$ formie pojedynczego guza.

6. W polu pieczęci herb urzędowy opata (na tarczy w kartuszu szachowany dwurzędowy skos skrzyżowany z pastorałem, na nich głowa św. Jana Chrzciciela na misie), powyżej inicjały. $\mathrm{Na}$ zewnątrz pola pieczęci grube obrzeżenie wieńcowe.

7. Owalna, $21 \times 19 \mathrm{~mm}$.

8. Odcisk przez papier na podkładzie $\mathrm{z}$ wosku czerwonego (1638).

9. Formuła sigillacyjna nieznana ${ }^{210}$.

\section{Nr 25}

\section{Opat Arnold Freiberger (1636-1672)}

1. Pieczęć mniejsza ${ }^{211}$ II, herbowa, potwierdzona w użyciu w latach 1648-1672.

3. Or.: AA Wrocław, sygn. VB6e, bpag.; sygn. VB8/e, bpag.; Dokumenty klasztoru w Henrykowie, nr 209 (3 XII 1651); AP Wrocław, Rep. 3, nr 734; Rep. 91, nr 890, s. 2; nr 900, s. 4 ; nr 909, s. 11; nr 920, s. 2*; nr 926, s. 2; GStA PK, VIII. HA Siegel, Wappen, Genealogie, Sammlung I 35 Stenzelsche Sammlung, Kasten $4^{212}$.

5. [FR(ater) • ]ARNOLDVS • / ABBAS • LVBENSIS : • Napis majuskułą w otoku, przerywniki między wyrazami w formie pojedynczych i potrójnych guzów.

6 . W polu pieczęci herb opactwa (na tarczy w kartuszu dzielonej w krzyż, pośrodku głowa św. Jana Chrzciciela na misie, w polu drugim i piątym szachowany dwurzędowy skos skrzyżowany z pastorałem, w polu trzecim i czwartym wspięty lew
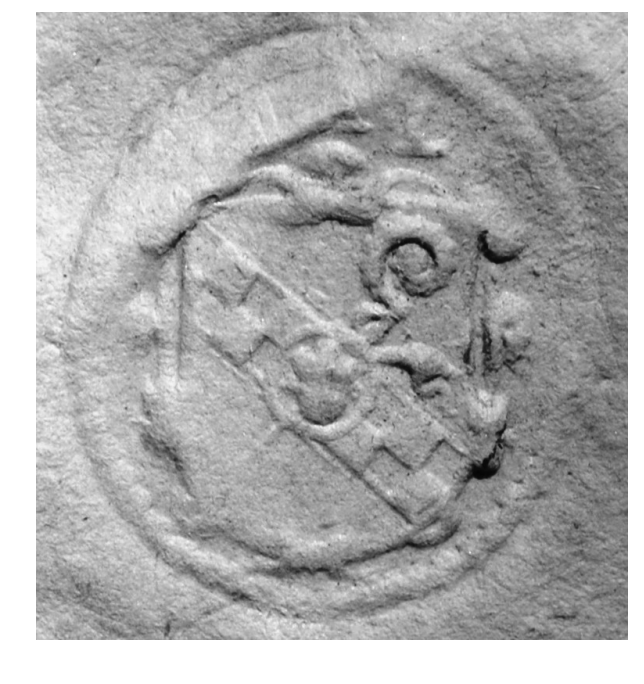
za kratą, nad kartuszem infuła w typie pretiosa, za nią pastorał o krzywaśni skierowanej na zewnątrz z żabkami na zewnętrznej krawędzi i motywem kwiatonu w wolucie). Na zewnątrz pola pieczęci, po zewnętrznej stronie napisu, obrzeżenie cienkie ciągłe i grube wieńcowe.

7. Owalna, $26 \times 23 \mathrm{~mm}$.

8. Odciski przez papier na podkładzie z wosku czerwonego $(1648,1650,1651,1659,1663,2$ z 1667, $1671,1672)$.

9. Formuła sigillacyjna nieznana ${ }^{213}$.

\section{Nr 26}

\section{Opat Arnold Freiberger (1636-1672)}

1. Pieczęć mniejsza III, herbowa, potwierdzona w użyciu w latach 1652-1654.

3. Or.: AA Wrocław, sygn. VB8/f, bpag.; AP Wrocław, Rep. 83, nr 525, s. 3.

5. $\operatorname{FR}($ ater $)[\bullet]$ ARNOLDVS $\bullet /$ ABBAS $\bullet$ LVBENSIS $[\bullet]$

Napis w otoku majuskułą, przerywniki między wyrazami w formie pojedynczych guzów.

6. W polu pieczęci herb opactwa (na tarczy w kartuszu dzielonej w krzyż, pośrodku głowa św. Jana Chrzciciela na misie, w polu drugim i piątym szachowany dwurzędowy skos skrzyżowany z pastorałem, w polu trzecim i czwartym wspięty lew za kratą, nad kartuszem infuła w typie pretiosa, za nią pastorał o krzywaśni skierowanej na zewnątrz z żabkami na zewnętrznej krawędzi i motywem kwiatonu w wolucie). Na zewnątrz pola pieczęci, po zewnętrznej stronie napisu, pojedyncze grube obrzeżenie ciągłe.

7. Owalna, $24 \times 22 \mathrm{~mm}$.

8. Odciski przez papier na podkładzie z wosku czerwonego $(1652,1654)$.

9. Formuła sigillacyjna nieznana ${ }^{214}$.

\section{Nr 27}

\section{Opat Arnold Freiberger (1636-1672)}

1. Pieczęć mniejsza IV, herbowa, potwierdzona w użyciu w $1671 \mathrm{r}$.

3. Or.: AA Wrocław, sygn. VB4b, bpag.

5. $\mathrm{F}$ (rater) $\mathrm{A}($ rnoldus $) /[\mathrm{L}($ ubensis $) \mathrm{A}($ bbas $)]$

Inicjały majuskułą w polu pieczęci.

6. W polu pieczęci herb opactwa (na tarczy w kartuszu dzielonej w krzyż, pośrodku głowa św. Jana Chrzciciela na misie, w polu drugim i piątym szachowany dwurzędowy skos skrzyżowany z pastorałem, w polu trzecim i czwartym wspięty lew za kratą, nad kartuszem infuła w typie pretiosa, za nią pastorał), na wysokości infuły i pastorału inicjały. Na zewnątrz pola pieczęci cienkie obrzeżenie ciągłe.

7. Ośmioboczna, $13 \times 11 \mathrm{~mm}$.

8. Odcisk w laku bezbarwnym (1671).

9. Formuła sigillacyjna nieznana ${ }^{215}$.

\footnotetext{
${ }^{213} \mathrm{~W}$ dokumentach z 1659, 1663 i 1672 r. występują formuły koroboracyjne odnoszące się do pieczęci i podpisu opata. W dokumentach z 1650, 1651 i 1667 r. występują formuły koroboracyjne odnoszące się do podpisu i pieczęci opata oraz innych współpieczętujących. W pozostałych dokumentach brak formuły sigillacyjnej lub koroboracyjnej.

${ }^{214} \mathrm{~W}$ dokumencie z 1652 r. występuje formuła koroboracyjna odnosząca się do podpisu i pieczęci opata oraz innych współpieczętujących. W pozostałych dokumentach brak formuły sigillacyjnej lub koroboracyjnej.

${ }^{215} \mathrm{~W}$ dokumencie z $1671 \mathrm{r}$. występuje formuła koroboracyjna odnosząca się do pieczęci i podpisu opata oraz konwentu.
} 


\section{Nr 28}

\section{Opat Jan IX Reich (1672-1691)}

1. Pieczęć większa, piesza, potwierdzona w użyciu w latach 1674-1691.

3. Or.: AP Wrocław, Rep. 91, nr 938*; nr 960a; nr 988, s. 14.

5. \& SIGIL $($ lum $) *$ FRATR $($ is $) *$ IOAN:/NIS * ABBATIS • LVBENS $(i s) \&$

Napis w otoku majuskułą na wstędze, przerywniki między wyrazami w formie podwójnych rozet, pojedynczych i podwójnych guzów, legendę rozpoczynają i zamykają wici roślinne. 6. W polu pieczęci opat $\mathrm{w}$ kukulli, $\mathrm{z}$ mucetem na ramionach, $\mathrm{w}$ infule $\mathrm{w}$ typie pretiosa na głowie, z pastorałem o krzywaśni zwróconej na zewnątrz w prawej ręce i księgą w lewej. Nodus pastorału w formie trzech kul nierównej wielkości, krzywaśń ozdobiona żabkami na zewnętrznej krawędzi i motywem kuli w wolucie, poniżej środkowej kuli zawieszony jest panniselus. Opat stoi w renesansowej arkadzie, ustawionej na niewysokim postumencie, z kolumnami na profilowanych cokołach, trzonach z przewiązkami i podwójnymi kapitelami, nad którymi wznosi się profilowany tuk. W tle stojącego opata zaznacza się mniejsza edykuła (lub portal) zwieńczona konchą. Po bokach widać wysunięte cokoły, na których ustawiono dwa anioły w tunikach. Poniżej arkady herb opactwa (na tarczy w kartuszu dzielonej w krzyż, pośrodku głowa św. Jana Chrzciciela na misie, w polu drugim i piątym szachowany dwurzędowy skos skrzyżowany z pastorałem, w polu trzecim i czwartym wspięty lew za kratą). Po wewnętrznej i zewnętrznej stronie wstęgi z napisem grube obrzeżenie wieńcowe.

7. Ostroowalna, 73 x $50 \mathrm{~mm}$.

8. Odciski w wosku czerwonym w puszkach metalowych z wieczkami, ozdobionymi motywem roślinnym, przywieszone na paskach pergaminowych $(1674,1680)$; odcisk przez papier na podkładzie z wosku czerwonego (1691).

9. Formuła sigillacyjna nieznana ${ }^{216}$.

\section{Nr 29}

\section{Opat Jan IX Reich (1672-1691)}

1. Pieczęć mniejsza I, herbowa, potwierdzona w użyciu w latach 1674-1681.

2. Tłok: MN Wrocław, Dział Numizmatyczno-Sfragistyczny, nr inw. MNWr XIV-270.

3. Or.: AP Wrocław, Rep. 91, nr 939, s. 6; AA Wrocław, Dokumenty klasztoru w Henrykowie, nr 231 (21 II, 6 III 1681).

4. Kopia: GStA PK, VIII. HA Siegel, Wappen, Genealogie, Sammlung I 22 Siegelsammlung aufgehobener Stifter und Klöster in Schlesien, t. 1, k. 3 (1 odcisk w laku czerwonym) ${ }^{217}$, t. 2, bpag. (1 odcisk w laku czerwonym) ${ }^{218}$; GStA PK, VIII. HA Siegel, Wappen, Genealogie, Sammlung I 35 Stenzelsche

\footnotetext{
${ }^{216}$ Formuły sigillacyjne dokumentów z lat 1674 i 1680, przy których przywieszono egzemplarze publikowanej pieczęci, odnoszą się do pieczęci opata i większej konwentu. W dokumencie z $1691 \mathrm{r}$. występuje formuła koroboracyjna odnosząca się do podpisów i pieczęci opata, konwentu oraz pieczęci większej i sądowej miasta Wołowa.

${ }^{217}$ W górnym fragmencie karty napis ciemnym piórem: 13. Stück, vom Fürstlichen Cistercienser Stift zu Leubus.

${ }^{218}$ Powyżej pieczęci napis ciemnym piórem: 13. Stück, vom Cistercienser Stift zu Leubus.
} 
Sammlung, Kasten 4 (1 odcisk w laku czerwonym) ${ }^{219}$; MN Wrocław, Dział Numizmatyczno-Sfragistyczny, Inwentarz kartkowy, bez nr inw. ${ }^{220}$; nr inw. MNWr XIV-2537, k. $3^{221}$; nr inw. MNWr XIV-S-X-2339.

5. FR(ater) : IOANNES • ABBAS • LVBENSIS •

Napis w otoku majuskułą, przerywniki między wyrazami w formie pojedynczych guzów i podwójnego guza.

6. W polu pieczęci herb opactwa (na tarczy w kartuszu dzielonej w krzyż, pośrodku głowa św. Jana Chrzciciela na misie, w polu drugim i piątym szachowany dwurzędowy skos skrzyżowany z pastorałem, w polu trzecim i czwartym wspięty lew za kratą, nad kartuszem infuła w typie pretiosa, za nią pastorał o krzywaśni skierowanej na zewnątrz z żabkami na zewnętrznej krawędzi). Na zewnątrz pola pieczęci, po zewnętrznej stronie napisu, pojedyncze grube obrzeżenie sznurowe.

7. Owalna, 27 × $25 \mathrm{~mm}$, wys. tłoka: $90 \mathrm{~mm}$, dł. osi odcisku: 26 × $23 \mathrm{~mm}$.

8. Tłok wykonany z żelaza, na uchwycie nacięcie w kształcie litery „X” między powtórzonymi guzami oraz numer inwentarzowy; odcisk przez papier na podkładzie z wosku czerwonego (1674); odcisk $\mathrm{w}$ wosku czerwonym w puszce drewnianej z wieczkiem, przywieszony na sznurach biało-czarnych (1681). 9. Formuła sigillacyjna nieznana ${ }^{222}$.

10. Opis: B. Marcisz-Czapla, Tłoki pieczętne i pieczęcie kościelne z terenu Śląska, w: Gloria Deo. Rzemiosło sakralne, t. 2, red. M. Korżel-Kraśna, Wrocław 2010, s. 112, nr 93.

\section{Nr 30}

\section{Opat Jan IX Reich (1672-1691)}

1. Pieczęć mniejsza II, herbowa, potwierdzona w użyciu w 1682 r.

3. Or.: AP Wrocław, Rep. 83, nr 673.

5. FR(ater) : IOANNES • / AB[B]AS • LVBENSIS •

Napis w otoku majuskułą, w obwódce niepełnej wewnętrznej cienkiej ciągłej i zewnętrznej grubej perełkowej ${ }^{223}$.

6. W polu pieczęci herb opactwa (na tarczy w kartuszu dzielonej w krzyż, pośrodku głowa św. Jana Chrzciciela na misie, w polu drugim i piątym szachowany dwurzędowy skos skrzyżowany z pastorałem, w polu trzecim i czwartym wspięty lew za kratą, nad kartuszem infuła w typie pretiosa, za nią pastorał o krzywaśni skierowanej na zewnątrz z żabkami na zewnętrznej krawędzi).

7. Owalna, $24 \times 21 \mathrm{~mm}$.

8. Odcisk w laku czerwonym (1682).

9. Formuła sigillacyjna nieznana ${ }^{224}$.

\section{Nr 31}

\section{Opat Jan IX Reich (1672-1691)}

1. Pieczęć mniejsza III, herbowa, potwierdzona w użyciu w $1686 \mathrm{r}$.

3. Or.: AP Wrocław, Rep. 91, nr 975, s. 3; nr 982, s. 7; nr 1016, s. 8.

5. F(rater) I(ohannes) / A(bbas) L(ubensis)

Inicjały majuskułą $\mathrm{w}$ polu pieczęci.

${ }^{219}$ Powyżej pieczęci napis ciemnym piórem: Johann A v Leubus ++1691.

${ }^{220} \mathrm{~W}$ górnym fragmencie karty napis ciemnym piórem: 13. Stück vom Cistercienser Stift zu Leubus.

${ }^{221}$ W górnym fragmencie karty napis ciemnym piórem: 13. Stück, vom Fürstlichen Cistercienser Stift zu Leubus.

${ }^{222} \mathrm{~W}$ dokumencie z 1674 r. występuje formuła koroboracyjna odnosząca się do pieczęci i podpisu opata i szlachcica. W dokumencie z $1681 \mathrm{r}$. brak formuły sigillacyjnej lub koroboracyjnej.

${ }^{223}$ Analizę napisu utrudnia niewłaściwie przeprowadzona konserwacja pieczęci wraz z dokumentem.

${ }^{224} \mathrm{~W}$ dokumencie, na którym odciśnięto pieczęć opata i innych współpieczętujących, brak formuły sigillacyjnej. 
6. W polu pieczęci herb opactwa (na tarczy w kartuszu dzielonej w krzyż, pośrodku głowa św. Jana Chrzciciela na misie, w polu drugim i piątym szachowany dwurzędowy skos skrzyżowany z pastorałem, w polu trzecim i czwartym wspięty lew za kratą, nad kartuszem infuła w typie pretiosa, za nią pastorał), po obu stronach infuły i pastorału inicjały.

7. Ośmioboczna, $14 \times 11 \mathrm{~mm}$.

8. Odciski w laku czerwonym (3 z 1686).

9. Formuła sigillacyjna nieznana ${ }^{225}$.

\section{Nr 32}

\section{Opat Dominik Krausenberger (1691-1692)}

1. Pieczęć mniejsza I, herbowa, niepotwierdzona w użyciu.

2. Tłok: MN Wrocław, Dział Numizmatyczno-Sfragistyczny, nr inw. MNWr XIV-259.

4. Kopia: GStA PK, VIII. HA Siegel, Wappen, Genealogie, Sammlung I 22 Siegelsammlung aufgehobener Stifter und Klöster in Schlesien, t. 1, k. 3 (1 odcisk w laku czerwonym) ${ }^{226}$; t. 2, bpag. (1 odcisk w laku czerwonym) $)^{227}$; GStA PK, VIII. HA Siegel, Wappen, Genealogie, Sammlung I 35 Stenzelsche Sammlung, Kasten 4 (1 odcisk w laku czerwonym) ${ }^{228}$; MN Wrocław, Dział Numizmatyczno-Sfragistyczny, Inwentarz kartkowy, bez nr inw. 229 ; nr inw. MNWr XIV-2537, k. 33230; nr inw. MNWr XIV-S-X-2333, MNWr XIV-S-X 2673.

\section{FR(ater) : DOMINICUS ABBAS LUBENSIS .}

Napis w otoku majuskułą, przerywniki między wyrazami w formie pojedynczego i podwójnego guza. 6. W polu pieczęci herb opactwa (na tarczy w kartuszu dzielonej w krzyż, pośrodku głowa św. Jana Chrzciciela na misie, w polu drugim i piątym szachowany dwurzędowy skos skrzyżowany z pastorałem, w polu trzecim i czwartym wspięty lew za kratą, nad kartuszem infuła w typie pretiosa, za nią pastorał o krzywaśni skierowanej na zewnątrz). Na zewnątrz pola pieczęci, po zewnętrznej stronie napisu, grube obrzeżenie wieńcowe.

7. Owalna, 30 x $29 \mathrm{~mm}$, wys. thoka: $38 \mathrm{~mm}$.

8. Płytka tłoka wykonana ze srebra, przechodzi w profilowaną żelazną podstawę, zakończoną czworobocznym trzpieniem, sporządzonym w tym samym metalu, do mocowania uchwytu (niezachowany), na którym numer inwentarzowy, na podstawie dwa guzy.

9. Formuła sigillacyjna nieznana.

10. Repr., opis: B. Marcisz-Czapla, Tłoki pieczętne i pieczęcie kościelne z terenu Śląska, w: Gloria Deo. Rzemiosło sakralne, t. 2, red. M. Korżel-Kraśna, Wrocław 2010, s. 113, nr 94.

\section{Nr 33}

\section{Opat Dominik Krausenberger (1691-1692)}

1. Pieczęć mniejsza II, herbowa, potwierdzona w użyciu (pieczęć wycięta z dokumentu).

3. Or.: GStA PK, VIII. HA Siegel, Wappen, Genealogie, Sammlung I 35 Stenzelsche Sammlung, Kasten $4^{231}$.

\footnotetext{
${ }^{225} \mathrm{~W}$ dokumentach, na których odciśnięto publikowaną pieczęć, występuje formuła koroboracyjna odnosząca się do podpisu i pieczęci opata oraz innych współpieczętujących.

${ }^{226}$ W górnym fragmencie karty napis ciemnym piórem: 13. Stück, vom Fürstlichen Cistercienser Stift zu Leubus.

227 Powyżej pieczęci napis ciemnym piórem: 13. Stück, vom Cistercienser Stift zu Leubus.

${ }^{228}$ Powyżej pieczęci napis ciemnym piórem: Dominicus Abt zu Leubus +1692.

${ }_{229} \mathrm{~W}$ górnym fragmencie karty napis ciemnym piórem: 13. Stück vom Cistercienser Stift zu Leubus.

${ }^{230}$ W górnym fragmencie karty napis ciemnym piórem: 13. Stück, vom Fürstlichen Cistercienser Stift zu Leubus.

${ }^{231} \mathrm{Na}$ przyciętym custodium napis ciemnym piórem: Dominicus Abt zu Leubus +1692.
} 


\section{FR(ater) : DOMINICUS • ABBAS LUBENSIS .}

Napis w otoku majuskułą, przerywniki między wyrazami w formie pojedynczych guzów i podwójnego guza.

6. W polu pieczęci herb opactwa (na tarczy w kartuszu dzielonej w krzyż, pośrodku głowa św. Jana Chrzciciela na misie, w polu drugim i piątym szachowany dwurzędowy skos skrzyżowany z pastorałem, $\mathrm{w}$ polu trzecim i czwartym wspięty lew za kratą, nad kartuszem infuła w typie pretiosa, za nią pastorał o krzywaśni skierowanej na zewnątrz). Na zewnątrz pola pieczęci, po zewnętrznej stronie napisu, grube obrzeżenie wieńcowe.

7. Owalna, 29 x $27 \mathrm{~mm}$.

8. Odcisk przez papier na podkładzie $\mathrm{z}$ wosku czerwonego.

9. Formuła sigillacyjna nieznana.

\section{Nr 34}

\section{Opat Ludwik Bauch (1696-1729)}

1. Pieczęć większa, piesza, potwierdzona w użyciu w latach 1697-1728.

3. Or.: AP Wrocław, Rep. 91, nr 1015c, s. 16*; 1169, s. 7.

5. [\&] SIGIL[(l)VM] FR(atr)IS・LVDO•/VICI * ABBATIS - LVBENS(is) [\&]

Napis w otoku majuskułą na wstędze, przerywniki między wyrazami w formie pojedynczych guzów i rozety.

6 . W polu pieczęci opat $\mathrm{w}$ kukulli, $\mathrm{z}$ mucetem na ramionach, $\mathrm{w}$ infule $\mathrm{w}$ typie pretiosa na głowie, $\mathrm{z}$ pastorałem o krzywaśni zwróconej na zewnątrz w prawej ręce i księgą w lewej. Nodus pastorału w formie trzech kul nierównej wielkości, krzywaśń ozdobiona żabkami na zewnętrznej krawędzi i motywem kuli w wolucie, poniżej środkowej kuli zawieszony jest panniselus. Opat stoi w renesansowej arkadzie, ustawionej na niewysokim postumencie, $\mathrm{z}$ kolumnami na profilowanych cokołach, trzonach z przewiązkami i podwójnymi kapitelami, nad którymi wznosi się profilowany łuk. W tle stojącego opata zaznacza się mniejsza edykuła (lub portal) zwieńczona konchą. Po bokach widać wysunięte cokoły, na których usta-

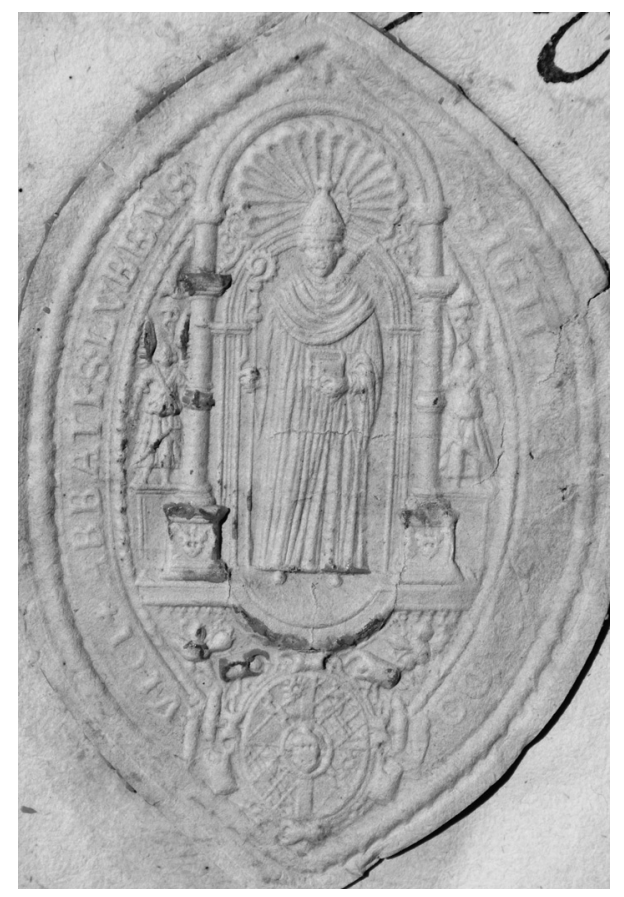
wiono dwa anioły w tunikach. Poniżej arkady herb opactwa (na tarczy w kartuszu dzielonej w krzyż, pośrodku głowa św. Jana Chrzciciela na misie, w polu drugim i piątym szachowany dwurzędowy skos skrzyżowany z pastorałem, w polu trzecim i czwartym wspięty lew za kratą). Po wewnętrznej i zewnętrznej stronie wstęgi z napisem grube obrzeżenie wieńcowe.

7. Ostroowalna, 75 x $50 \mathrm{~mm}$.

8. Odciski przez papier na podkładzie z wosku czerwonego $(1697,1728)$.

9. Formuła sigillacyjna nieznana ${ }^{232}$.

${ }^{232}$ Formuły sigillacyjne dokumentów, przy których zachowały się egzemplarze publikowanej pieczęci, odnoszą się do pieczęci opata $\mathrm{i}$ innych współpieczętujących. 


\section{Nr 35}

\section{Opat Ludwik Bauch (1696-1729)}

1. Pieczęć mniejsza I, herbowa, potwierdzona w użyciu w latach 1697-1727.

3. Or.: AP Wrocław, Rep. 28, nr 44, s. 10; Rep. 91, nr 1012b, s. 6; nr 1015a, s. 11; nr 1036, s. 4; nr 1040, s. 8 ; nr 1042 , s. 7 ; nr 1050 , s. 5 ; nr 1057 b, s. 6 ; nr 1069 , s. 4 ; nr 1084, s. 6; nr 1085, s. 5; nr 1086 , s. 3 ; nr 1091 , s. 8 ; nr 1093 , s. 13 ; nr 1094, s. 4 ; nr 1111, s. 4 ; nr 1115, s. 3 ; nr 1121, s. 6 ; nr 1122, s. 5; nr 1139 , s. 2 ; nr 1142 , s. 7 ; nr 1143 , s. 4 ; nr 1146 , s. 3 ; nr 1152 , s. 6 ; nr 1161 , s. 9.

5. L(udovicus) $\mathrm{A}($ bbas $) / \mathrm{L}($ ubensis $)$

Inicjały majuskułą $\mathrm{w}$ polu pieczęci.

6. W polu pieczęci herb opactwa (na tarczy w kartuszu dzielonej w krzyż, pośrodku głowa św. Jana Chrzciciela na misie, w polu drugim i piątym szachowany dwurzędowy skos skrzyżowany z pastorałem, w polu trzecim i czwartym wspięty lew za kratą, nad kartuszem infuła w typie pretiosa, za nią pastorał o krzywaśni skierowanej na zewnątrz z żabkami na zewnętrznej krawędzi), po obu stronach infuły i pastorału inicjały. Na zewnątrz pola pieczęci cienkie obrzeżenie ciągłe oraz grube wieńcowe. 7. Owalna, $18 \times 16 \mathrm{~mm}$.

8. Odciski w laku czerwonym (2 z 1697, 1701, 3 z 1702, 1703, 1704, 1707, 4 z 1711, 1712, 1713, 2 z 1714, 2 z 1716, 3 z 1720, 1721, 1722, 1727).

9. Formuła sigillacyjna nieznana ${ }^{233}$.

\section{Nr 36}

\section{Opat Ludwik Bauch (1696-1729)}

1. Pieczęć mniejsza II, herbowa, potwierdzona w użyciu w latach 1700-1721.

3. Or.: AP Wrocław, Rep. 3, nr 726a; Rep. 28, nr 44, s. 4; Rep. 91, nr 1023, s. 4; nr 1026b, s. 2; nr 1095, s. 4; nr 1099, s. 4; nr 1135b; nr 1149, s. 6; Rep. 125, nr 942a.

5. * FR(ater) : LVDOVICVS • ABBAS • LVBENSIS *

Napis w otoku majuskułą, przerywniki między wyrazami w formie pojedynczych guzów i podwójnego guza, legendę rozpoczyna i zamyka gwiazda.

6. W polu pieczęci herb opactwa (na tarczy w kartuszu dzielonej w krzyż, pośrodku głowa św. Jana Chrzciciela na misie, w polu drugim i piątym szachowany dwurzędowy skos skrzyżowany z pastorałem, w polu trzecim i czwartym wspięty lew za kratą, nad kartuszem infuła w typie pretiosa, za nią pastorał o krzywaśni skierowanej na zewnątrz). Na zewnątrz pola pieczęci, po zewnętrznej stronie napisu, obrzeżenie cienkie ciągłe i grube wieńcowe.

7. Owalna, $30 \times 27 \mathrm{~mm}$.

8. Odciski przez papier na podkładzie z wosku czerwonego (3 z 1700, 2 z 1713, 1721); odcisk w wosku czerwonym w puszce drewnianej, przywieszony na niebieskim sznurze (1706); odciski w wosku czerwonym w puszkach metalowych bez wieczek, przywieszone na paskach pergaminowych $(1704,1719)$.

9. Formuła sigillacyjna nieznana ${ }^{234}$.

\section{Nr 37}

\section{Opat Ludwik Bauch (1696-1729)}

1. Pieczęć mniejsza III, herbowa, potwierdzona w użyciu w latach 1701-1724.

${ }^{233} \mathrm{~W}$ dokumentach występują formuły koroboracyjne odnoszące się do podpisu i pieczęci (pieczęci i podpisu) opata i innych współpieczętujących.

${ }^{234}$ Fomuły sigillacyjne dokumentów z 1704 i 1709 r., przy których przywieszono egzemplarze publikowanej pieczęci, odnoszą się do pieczęci opata i mniejszej konwentu. W pozostałych dokumentach występują formuły koroboracyjne odnoszące się do pieczęci i podpisów opata lub też innych współpieczętujących. 
3. Or.: AA Wrocław, sygn. VB4b, bpag.; AP Wrocław, Rep. 85, nr 183, 189, 217, 228; Rep. 91, nr 1034, s. 8; nr 1098, s. 12.

5. $\mathrm{F}$ (rater) $\mathrm{L}($ udovicus $) / \mathrm{A}($ bbas $) \mathrm{L}($ ubensis $)$

Inicjały majuskułą $\mathrm{w}$ polu pieczęci.

6. W polu pieczęci herb opactwa (na tarczy w kartuszu dzielonej w krzyż, pośrodku głowa św. Jana Chrzciciela na misie, w polu drugim i piątym szachowany dwurzędowy skos skrzyżowany z pastorałem, $\mathrm{w}$ polu trzecim i czwartym wspięty lew za kratą, nad kartuszem infuła w typie pretiosa, za nią pastorał o krzywaśni skierowanej na zewnątrz), po obu stronach infuły i pastorału inicjały. Na zewnątrz pola pieczęci dwa obrzeżenia cienkie i grube ciągłe.

7. Ośmioboczna, $14 \times 12 \mathrm{~mm}$.

8. Odciski w laku czerwonym $(1701,1704,1706,1709,1713,1721,1724)$.

9. Formuła sigillacyjna nieznana ${ }^{235}$.

\section{Nr 38}

\section{Opat Ludwik Bauch (1696-1729)}

1. Pieczęć mniejsza IV, herbowa, niepotwierdzona w użyciu.

4. Kopia: Zakład Narodowy im. Ossolińskich we Wrocławiu, Dział Numizmatyczny, pieczęć lakowa z kolekcji Schaffgotschów, niezidentyfikowana ${ }^{236}$.

5. L(udovicus) $\mathrm{A}($ bbas $) / \mathrm{L}($ ubensis $)$

Inicjały majuskuła $\mathrm{w}$ polu pieczęci.

6. W polu pieczęci herb opactwa (na tarczy w kartuszu dzielonej w krzyż, pośrodku głowa św. Jana Chrzciciela na misie, w polu drugim i piątym szachowany dwurzędowy skos skrzyżowany z pastorałem, w polu trzecim i czwartym wspięty lew za kratą, nad kartuszem infuła w typie pretiosa, za nią pastorał o krzywaśni skierowanej na zewnątrz), po obu stronach infuły inicjały. Na zewnątrz pola pieczęci grube obrzeżenie ciągłe.

7. Okrągła, ø $18,5 \mathrm{~mm}$.

9. Formuła sigillacyjna nieznana.

\section{Nr 39}

\section{Opat Dominik II Süßmuth (1729-1732)}

1. Pieczęć mniejsza, herbowa, potwierdzona w użyciu w 1730 r.

3. Or.: AP Wrocław, Rep. 91, nr 1181, s. 6.

5. $\mathrm{D}$ (ominicus) $\mathrm{A}($ bbas $) /[\mathrm{L}($ ubensis $)]$

Inicjały majuskuła w polu pieczęci, przerywnik między wyrazami w formie pojedynczego guza.

6. W polu pieczęci herb opactwa (na tarczy w kartuszu dzielonej w krzyż, pośrodku głowa św. Jana Chrzciciela na misie, w polu drugim i piątym szachowany dwurzędowy skos skrzyżowany z pastorałem, w polu trzecim i czwartym wspięty lew za kratą, nad kartuszem infuła, za nią pastorał o krzywaśni skierowanej na zewnątrz), po obu stronach infuły i pastorału inicjały. Na zewnątrz pola pieczęci grube obrzeżenie ciągłe (?).

7. Owalna, $19 \times 16 \mathrm{~mm}$.

8. Odcisk w laku czerwonym (1730).

9. Formuła sigillacyjna nieznana ${ }^{237}$.

\footnotetext{
${ }^{235}$ W dokumentach z 1701 i 1713 r. występuje formuła koroboracyjna odnosząca się do pieczęci i podpisów opata i innych współpieczętujących. W pozostałych dokumentach brak formuł koroboracyjnych lub sigillacyjnych.

${ }^{236} \mathrm{Za}$ wskazanie na tę pieczęć serdecznie dziękuję panu Robertowi Forysiakowi-Wójcińskiemu.

${ }^{237} \mathrm{~W}$ dokumencie występuje formuła koroboracyjna odnosząca się do podpisów i pieczęci opata i innych współpieczętujących.
} 


\section{Nr 40}

\section{Opat Konstantyn Beyer (1733-1747)}

1. Pieczęć większa, piesza, potwierdzona w użyciu w $1740 \mathrm{r}$.

3. Or.: AP Wrocław, Rep. 91, nr 1212aa.

5. \& SIGIL(lum) : FR(atris) : CON[ST]AN/TINI • ABBATIS

- LVBENS(is) \&

Napis w otoku majuskułą na wstędze, przerywniki między wyrazami w formie pojedynczych i podwójnych guzów, legendę rozpoczyna i zamyka ornament roślinny.

6. W polu pieczęci opat w kukulli, z mucetem na ramionach, $\mathrm{w}$ infule $\mathrm{w}$ typie pretiosa na głowie, $\mathrm{z}$ pastorałem o krzywaśni zwróconej na zewnątrz w prawej ręce i księgą w lewej. Nodus pastorału w formie trzech kul nierównej wielkości, krzywaśń ozdobiona żabkami na zewnętrznej krawędzi i motywem kuli w wolucie, poniżej środkowej kuli zawieszony jest panniselus. Opat stoi w renesansowej arkadzie, ustawionej na niewysokim postumencie, z kolumnami na profilowanych cokołach, trzonach z przewiązkami i podwójnymi kapitelami, nad którymi wznosi się profilowany tuk. W tle stojącego opata zaznacza się mniejsza edykuła (lub portal) zwieńczona konchą. Po bokach

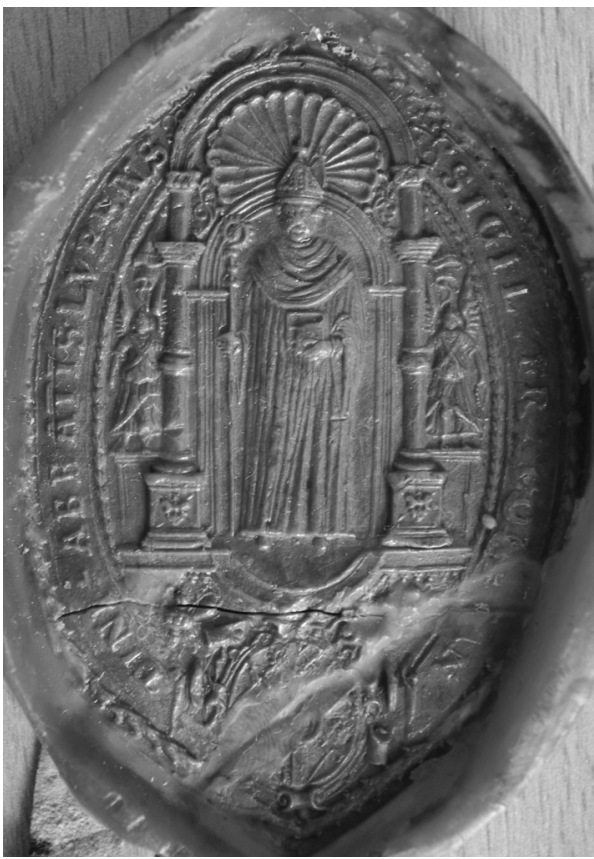
widać wysunięte cokoły, na których ustawiono dwa anioły w tunikach. Poniżej arkady herb opactwa (na tarczy w kartuszu dzielonej w krzyż, pośrodku głowa św. Jana Chrzciciela na misie, w polu drugim i piątym szachowany dwurzędowy skos skrzyżowany z pastorałem, w polu trzecim i czwartym wspięty lew za kratą). Po wewnętrznej i zewnętrznej stronie wstęgi $\mathrm{z}$ napisem grube obrzeżenie wieńcowe.

7. Ostroowalna, 70 x $50 \mathrm{~mm}$.

8. Odcisk w wosku czerwonym (dawniej w puszcze metalowej), przywieszony na pasku pergaminowym (1740).

9. Formuła sigillacyjna nieznana ${ }^{238}$.

\section{Nr 41}

\section{Opat Konstantyn Beyer (1733-1747)}

1. Pieczęć mniejsza I, herbowa, potwierdzona w użyciu w 1734 r.

3. Or.: AP Wrocław, Rep. 91, nr 1205, s. 6.

5. C(onstantinus) $\mathrm{A}($ bbas $) / \mathrm{L}($ ubensis $)$

Inicjały majuskułą w polu pieczęci.

6. W polu pieczęci herb opactwa (na tarczy w kartuszu dzielonej w krzyż, pośrodku głowa św. Jana Chrzciciela na misie, w polu drugim i piątym szachowany dwurzędowy skos skrzyżowany z pastorałem, w polu trzecim i czwartym wspięty lew za kratą, nad kartuszem infuła w typie pretiosa, za nią pastorał o krzywaśni skierowanej na zewnątrz), po obu stronach infuły i pastorału inicjały. Na zewnątrz pola pieczęci grube obrzeżenie wieńcowe i cienkie ciągłe.

7. Owalna, $21 \times 19 \mathrm{~mm}$.

8. Odcisk w laku czerwonym (1734).

9. Formuła sigillacyjna nieznana ${ }^{239}$.

${ }^{238}$ Formuła sigillacyjna dokumentu, przy którym zachowała się publikowana pieczęć, odnosi się do pieczęci opata i większej konwentu.

${ }^{239} \mathrm{~W}$ dokumencie występuje formuła koroboracyjna odnosząca się do pieczęci i podpisów opata i innych współpieczętujących. 


\section{Nr 42}

\section{Opat Konstantyn Beyer (1733-1747)}

1. Pieczęć mniejsza II, herbowa, potwierdzona w użyciu w latach 1737-1747.

3. Or.: AP Wrocław, Rep. 83, nr 1028*; Rep. 91, nr 1211, s. 3; nr 1214b; nr 1221, s. 3.

5. C(onstantinus) $\mathrm{A}($ bbas $) / \mathrm{L}($ ubensis $)$

Inicjały majuskułą $\mathrm{w}$ polu pieczęci.

6. W polu pieczęci herb opactwa (na tarczy w kartuszu dzielonej w krzyż, pośrodku głowa św. Jana Chrzciciela na misie, w polu drugim i piątym szachowany dwurzędowy skos skrzyżowany z pastorałem, $\mathrm{w}$ polu trzecim i czwartym wspięty lew za kratą, nad kartuszem infuła w typie pretiosa, za nią pastorał o krzywaśni skierowanej na zewnątrz), po obu stronach infuły i pastorału inicjały. Na zewnątrz pola pieczęci cienkie obrzeżenie ciągłe i grube sznurowe.

7. Owalna, 19 x $17 \mathrm{~mm}$.

8. Odciski w laku czerwonym $(1737,1742,1744,1747)$.

9. Formuła sigillacyjna nieznana ${ }^{240}$.

\section{Nr 43}

\section{Opat Konstantyn Beyer (1733-1747)}

1. Pieczęć mniejsza III, herbowa, potwierdzona w użyciu w latach 1743-1746.

3. Or.: AP Wrocław, Rep. 61, nr 273, 280, 282, 284; Rep. 91, nr 1216, s. 13.

5. CONSTANTINVS ABBAS LVBENSIS \&

Napis w otoku majuskułą, w podwójnej obwódce sznurowej, legendę zamyka ornament roślinny.

6. W polu pieczęci herb opactwa (na tarczy w kartuszu dzielonej w krzyż, pośrodku głowa św. Jana Chrzciciela na misie, w polu drugim i piątym szachowany dwurzędowy skos skrzyżowany z pastorałem, w polu trzecim i czwartym wspięty lew za kratą, nad kartuszem infuła w typie pretiosa, za nią pastorał o krzywaśni skierowanej na zewnątrz). Na zewnątrz pola pieczęci, po zewnętrznej stronie napisu, obrzeżenie grube wieńcowe.

7. Owalna, 29 x $27 \mathrm{~mm}$.

8. Odciski przez papier na podkładzie z wosku czerwonego (1743, 2 z 1744, 1745, 1746).

9. Formuła sigillacyjna nieznana ${ }^{241}$.

\section{Nr 44}

\section{Opat Tobiasz Stusche (1747-1757)}

1. Pieczęć mniejsza I, herbowa, potwierdzona w użyciu w latach 1747-1756.

2. Tlok: MN Wrocław, Dział Numizmatyczno-Sfragistyczny, nr inw. MNWr XIV-274.

3. Or.: AP Wrocław, Rep. 91, nr 1226, s. 2; nr 1252, s. 5.

4. Kopia: GStA PK, VIII. HA Siegel, Wappen, Genealogie, Sammlung I 22 Siegelsammlung aufgehobener Stifter und Klöster in Schlesien, t. 1, k. 3 (1 odcisk w laku czerwonym) ${ }^{242}$, t. 2 , bpag. (1 odcisk w laku czerwonym ${ }^{243}$; GStA PK, VIII. HA Siegel, Wappen, Genealogie, Sammlung I 35 Stenzelsche

\footnotetext{
${ }^{240} \mathrm{~W}$ dokumentach występują formuły koroboracyjne odnoszące się do podpisu i pieczęci (pieczęci i podpisów) opata i innych współpieczętujących.

${ }^{241} \mathrm{~W}$ dokumentach występują formuły koroboracyjne odnoszące się do podpisu i pieczęci opata $(1743,1744,1745)$ oraz ponadto do podpisu i pieczęci najwyższego mistrza klasztoru krzyżowców z Czerwoną Gwiazdą we Wrocławiu (1746).

${ }^{242}$ W górnym fragmencie karty napis ciemnym piórem: 13. Stück, vom Fürstlichen Cistercienser Stift zu Leubus.

${ }^{243}$ Powyżej pieczęci napis ciemnym piórem: 13. Stück, vom Cistercienser Stift zu Leubus.
} 
Sammlung, Kasten 4 (1 odcisk w laku czerwonym) ${ }^{244}$; MN Wrocław, Dział Numizmatyczno-Sfragistyczny. Inwentarz kartkowy, bez nr inw. ${ }^{245}$; nr inw. MNWr XIV-2537, k. $3^{246}$; nr inw. MNWr XIV-S-X-2342. 5. . $\mathrm{T}$ (obias) $\mathrm{A}($ bbas $) / \mathrm{L}($ ubensis $)$

Inicjały majuskułą w polu pieczęci, na początku guz w dolnym indeksie oraz po literach „T” i „L" na oznaczenie skrótu.

6. W polu pieczęci herb opactwa (na tarczy w kartuszu dzielonej w krzyż, pośrodku głowa św. Jana Chrzciciela na misie, w polu drugim i piątym szachowany dwurzędowy skos skrzyżowany z pastorałem, w polu trzecim i czwartym wspięty lew za kratą, nad kartuszem infuła w typie pretiosa, za nią pastorał o krzywaśni skierowanej na zewnątrz), po obu stronach infuły i pastorału inicjały. Na zewnątrz pola pieczęci grube obrzeżenie sznurowe i cienkie ciągłe.

7. Owalna, 22 x $20 \mathrm{~mm}$, wys. tłoka: $99 \mathrm{~mm}$, dł. osi odcisku: 21 x 19,5 mm.

8. Tłok wykonany z żelaza, uchwyt ośmioboczny, na którym numer inwentarzowy, na rancie płytki nacięcie w kształcie litery „X”; odciski w laku czerwonym $(1747,1756)$.

9. Formuła sigillacyjna nieznana ${ }^{247}$.

10. Opis: B. Marcisz-Czapla, Tłoki pieczętne i pieczęcie kościelne z terenu Śląska, w: Gloria Deo. Rzemiosto sakralne, t. 2, red. M. Korżel-Kraśna, Wrocław 2010, s. 115, nr 100.

\section{$\mathrm{Nr} 45$}

\section{Opat Tobiasz Stusche (1747-1757)}

1. Pieczęć mniejsza II, herbowa, potwierdzona w użyciu w latach 1747-1755.

3. Or.: AP Wrocław, Rep. 61, nr 293, s. 2; nr 303, s. 2; Rep. 91, nr 1227, s. 3; nr 1239c; nr 1248b; nr 1249 , s. 5.

5. $\cdot \mathrm{T}($ obias $) \cdot \mathrm{A}($ bbas $) \bullet / \mathrm{L}($ ubensis $)$

Inicjały majuskułą w polu pieczęci, przerywniki między wyrazami w formie pojedynczych guzów, guz w dolnym indeksie po literze „L” na oznaczenie skrótu.

6. W polu pieczęci herb opactwa (na tarczy w kartuszu dzielonej w krzyż, pośrodku głowa św. Jana Chrzciciela na misie, w polu drugim i piątym szachowany dwurzędowy skos skrzyżowany z pastorałem, w polu trzecim i czwartym wspięty lew za kratą, nad kartuszem infuła w typie pretiosa, za nią pastorał o krzywaśni skierowanej na zewnątrz), po obu stronach infuły i pastorału inicjały. Kartusz okolony gałązkami palmowymi o końcach skrzyżowanych u dołu. Na zewnątrz pola pieczęci grube obrzeżenie wieńcowe.

7. Owalna, $29 \times 27 \mathrm{~mm}$.

8. Odciski w laku czerwonym $(1747,1755)$; odciski przez papier podkładzie $\mathrm{z}$ wosku czerwonego (1747, 1749); odciski w wosku czerwonym w puszkach metalowych, na jednej zachowane wieczko $\mathrm{z}$ ornamentem roślinnym, przywieszone na paskach pergaminowych (2 z 1750).

9. Formuła sigillacyjna nieznana ${ }^{248}$.

${ }^{244}$ Powyżej pieczęci napis ciemnym piórem: Tobias A. v Leubus 1747-1755.

${ }^{245} \mathrm{~W}$ górnym fragmencie karty napis ciemnym piórem: 13. Stück vom Cistercienser Stift zu Leubus.

${ }^{246}$ W górnym fragmencie karty napis ciemnym piórem: 13. Stück, vom Fürstlichen Cistercienser Stift zu Leubus.

$247 \mathrm{~W}$ dokumentach występują formuły koroboracyjne odnoszące się do podpisu i pieczęci opata i innych współpieczętujących.

${ }^{248}$ Formuly sigillacyjne dokumentów (2 z 1750), przy którym zachowała się publikowana pieczęć, odnoszą się do pieczęci opata i średniej konwentu. W pozostałych dokumentach występuje formuła koroboracyjna odnosząca się do podpisu i pieczęci opata $(1747,1749)$ oraz ponadto do innych współpieczętujących $(1747,1755)$. 


\section{Nr 46}

\section{Opat Tobiasz Stusche (1747-1757)}

1. Pieczęć mniejsza III, herbowa, niepotwierdzona w użyciu.

2. Tłok: MN Wrocław, Dział Numizmatyczno-Sfragistyczny, nr inw. MNWr XIV-269.

4. Kopia: GStA PK, VIII. HA Siegel, Wappen, Genealogie, Sammlung I 22 Siegelsammlung aufgehobener Stifter und Klöster in Schlesien, t. 1, k. 3 (1 odcisk w laku czerwonym) ${ }^{249}$; t. 2, bpag. (1 odcisk w laku czerwonym ${ }^{250}$; GStA PK, VIII. HA Siegel, Wappen, Genealogie, Sammlung I 35 Stenzelsche Sammlung, Kasten 4 (1 odcisk w laku czerwonym) ${ }^{251}$; MN Wrocław, Dział Numizmatyczno-Sfragistyczny, Inwentarz kartkowy bez nr inw. ${ }^{252}$; $\mathrm{nr}$ inw. MNWr XIV-2537, k. $3^{253}$; nr inw. MNWr XIV-S-X-2334.

5. . $\mathrm{T}($ obias $) \mathrm{A}($ bbas $) \mathrm{L}($ ubensis $)$

Inicjały majuskułą w polu pieczęci, na początku guz w dolnym indeksie oraz po literach „T”, „A ” i „L” na oznaczenie skrótu.

6. W polu pieczęci herb urzędowy opata (na tarczy w kartuszu szachowany dwurzędowy skos skrzyżowany z pastorałem, na nim głowa św. Jana Chrzciciela na misie), powyżej inicjały. Na zewnątrz pola pieczęci grube obrzeżenie wieńcowe.

7. Owalna, 21 x $19 \mathrm{~mm}$, wys. tłoka: $106 \mathrm{~mm}$.

8. Płytka tłoka wykonana ze srebra, uchwyt ośmioboczny żelazny, na którym numer inwentarzowy, na uchwycie nacięcie w kształcie litery „X”.

10. Repr., opis: B. Marcisz-Czapla, Tłoki pieczętne i pieczęcie kościelne z terenu Ślaska, w: Gloria Deo. Rzemiosło sakralne, t. 2, red. M. Korżel-Kraśna, Wrocław 2010, s. 115, nr 101.

\section{Nr 47}

\section{Opat Wilhelm Steiner (1757-1769)}

1. Pieczęć większa, piesza, potwierdzona w użyciu w 1759 r.

3. Or.: AP Wrocław, Oddział Legnica, Dokumenty cechowe miasta Legnicy, sygn. 565.

\section{SIGILLUM GUILLELMI / ABBATIS LUBENSIS •}

Napis w otoku majuskułą na wstęgach, między którymi widoczne ornamenty roślinne, legendę kończy pojedynczy guz. 6 . W polu pieczęci opat $\mathrm{w}$ kukulli, $\mathrm{z}$ mucetem na ramionach, $\mathrm{w}$ infule w typie pretiosa na głowie, z pastorałem o krzywaśni zwróconej na zewnątrz w prawej ręce i księgą w lewej. Nodus pastorału w formie trzech kul nierównej wielkości, krzywaśń ozdobiona żabkami na zewnętrznej krawędzi i motywem kuli W wolucie, poniżej środkowej kuli zawieszony jest panniselus. Opat stoi w renesansowej arkadzie, ustawionej na niewysokim postumencie, z kolumnami na profilowanych cokołach, trzonach z przewiązkami i podwójnymi kapitelami, nad którymi wznosi się profilowany łuk. W tle stojącego opata zaznacza się mniejsza edykuła (lub portal) zwieńczona konchą. Po bokach widać wysunięte cokoły, na których ustawiono dwa anioły

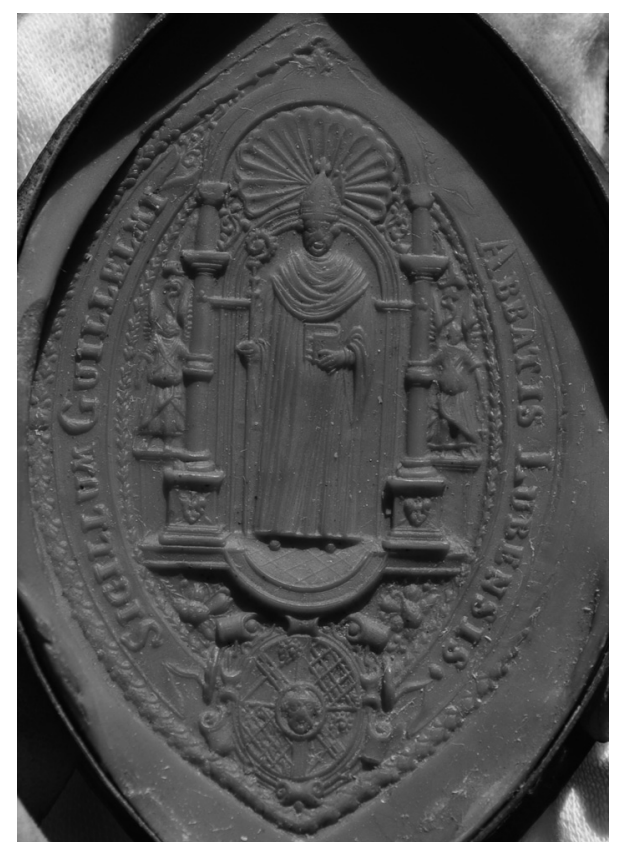

\footnotetext{
${ }^{249}$ W górnym fragmencie karty napis ciemnym piórem: 13. Stück, vom Fürstlichen Cistercienser Stift zu Leubus.

${ }^{250}$ Powyżej pieczęci napis ciemnym piórem: 13. Stück, vom Cistercienser Stift zu Leubus.

251 Powyżej pieczęci napis ciemnym piórem: Tobias (Stusche) A: v Leubus +1755.

${ }^{252} \mathrm{~W}$ górnym fragmencie karty napis ciemnym piórem: 13. Stück vom Cistercienser Stift zu Leubus.

${ }^{253} \mathrm{~W}$ górnym fragmencie karty napis ciemnym piórem: 13. Stück, vom Fürstlichen Cistercienser Stift zu Leubus.
} 
w tunikach. Poniżej arkady herb opactwa (na tarczy w kartuszu dzielonej w krzyż, pośrodku głowa św. Jana Chrzciciela na misie, w polu drugim i piątym szachowany dwurzędowy skos skrzyżowany z pastorałem, w polu trzecim i czwartym wspięty lew za kratą). Po wewnętrznej i zewnętrznej stronie wstęgi z napisem grube obrzeżenie wieńcowe.

7. Ostroowalna, 73 x $50 \mathrm{~mm}$.

8. Odcisk w wosku czerwonym w puszcze metalowej z wieczkiem, ozdobionym dwoma lekko zakrzywionymi figurami przypominającymi półksiężyc między guzami, przywieszony na pasku pergaminowym (1759).

9. Formuła sigillacyjna nieznana ${ }^{254}$.

\section{Nr 48}

\section{Opat Wilhelm Steiner (1757-1769)}

1. Pieczęć mniejsza I, herbowa ${ }^{255}$, potwierdzona w użyciu w $1757 \mathrm{r}$.

3. Or.: AP Wrocław, Rep. 91, nr 1253, s. 8.

5. $\mathrm{G}$ (uillelmus) / A(bbas) $\mathrm{L}$ (ubensis)

Inicjały majuskułą $\mathrm{w}$ polu pieczęci.

6. W polu pieczęci herb opactwa (na tarczy w kartuszu dzielonej w krzyż, pośrodku głowa św. Jana Chrzciciela na misie, w polu drugim i piątym szachowany dwurzędowy skos skrzyżowany z pastorałem, w polu trzecim i czwartym wspięty lew za kratą), zwieńczony kapeluszem rangowym między inicjałami ze sznurami, wiązaniami i chwostami po sześć w układzie 1,2, 3. Na zewnątrz pola pieczęci cienkie obrzeżenie ciągłe.

7. Okrągła, ø $18 \mathrm{~mm}$.

8. Odcisk w laku czerwonym (1757).

9. Formuła sigillacyjna nieznana ${ }^{256}$.

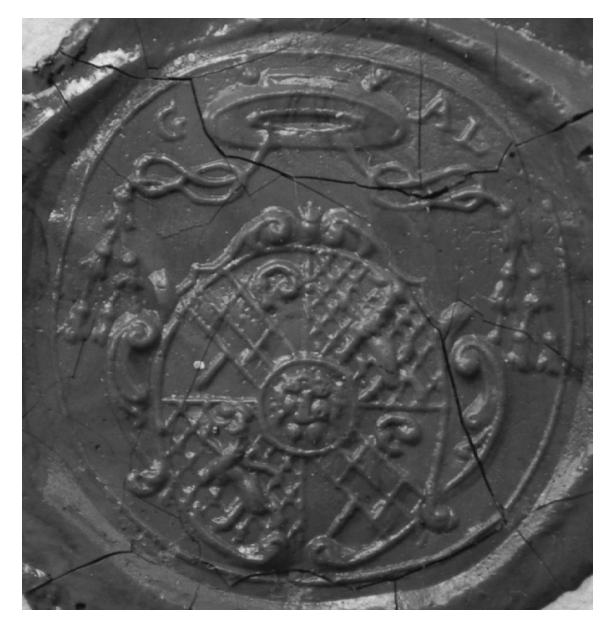

\section{Nr 49}

\section{Opat Wilhelm Steiner (1757-1769)}

1. Pieczęć mniejsza II, herbowa, potwierdzona w użyciu w latach 1764-1768.

3. Or.: AA Wrocław, Dokumenty klasztoru w Henrykowie, nr 273 (16 I 1764); AP Wrocław, Rep. 91, nr 1264, s. 4; nr 1265; nr 1266, s. 4; nr 1267a, s. 3; nr 1267b; nr 1268, s. 10.

5. $\mathrm{G}($ uillelmus $) \mathrm{A}($ bbas $) /$. L(ubensis $)$

Inicjały majuskułą $\mathrm{w}$ polu pieczęci, przerywnik między inicjałami $\mathrm{w}$ formie pojedynczego guza, guz w dolnym indeksie po literze „L” na oznaczenie skrótu.

6. W polu pieczęci herb opactwa (na tarczy w kartuszu dzielonej w krzyż, pośrodku głowa św. Jana Chrzciciela na misie, w polu drugim i piątym szachowany dwurzędowy skos skrzyżowany z pastorałem, w polu trzecim i czwartym wspięty lew za kratą, nad kartuszem infuła w typie pretiosa, za nią pastorał o krzywaśni skierowanej na zewnątrz), powyżej inicjały. $\mathrm{Na}$ zewnątrz pola pieczęci grube obrzeżenie ciągłe.

${ }^{254}$ Formuła sigillacyjna dokumentu, przy którym zachowała się publikowana pieczęć, odnosi się do pieczęci opata i większej konwentu.

255 Pieczęć została następnie przerytowana; zob. inwentarz, nr 51.

${ }^{256} \mathrm{~W}$ dokumencie występuje formuła koroboracyjna odnosząca się do podpisu i pieczęci opata, konwentu i innych współpieczętujących. 
7. Owalna, $23 \times 21 \mathrm{~mm}$.

8. Odciski w laku czerwonym (1764, 3 z 1766, 2 z 1767, 1768).

9. Formuła sigillacyjna nieznana ${ }^{257}$.

\section{Nr 50}

\section{Opat Wilhelm Steiner (1757-1769)}

1. Pieczęć mniejsza III, herbowa, potwierdzona w użyciu w 1765 r.

3. Or.: AP Wrocław, Rep. 91, nr 1261, s. 5.

5. G(uillelmus) $\mathrm{A}($ bbas $) / \mathrm{L}($ ubensis $)$

Inicjały majuskułą $\mathrm{w}$ polu pieczęci.

6. W polu pieczęci herb opactwa (na tarczy w kartuszu dzielonej w krzyż, pośrodku głowa św. Jana Chrzciciela na misie, w polu drugim i piątym szachowany dwurzędowy skos skrzyżowany z pastorałem, w polu trzecim i czwartym wspięty lew za kratą, nad kartuszem infuła w typie pretiosa, za nią pastorał o krzywaśni skierowanej na zewnątrz), po obu stronach infuły inicjały, całość zwieńczona kapeluszem rangowym ze sznurami, wiązaniami i chwostami po sześć w układzie 1, 2, 3. Na zewnątrz pola pieczęci grube obrzeżenie ciągłe.

7. Owalna, $24 \times 22 \mathrm{~mm}$.

8. Odcisk w laku czerwonym (1765).

9. Formuła sigillacyjna nieznana ${ }^{258}$.

\section{$\operatorname{Nr} 51$}

\section{Opat Wilhelm Steiner (1757-1769)}

1. Pieczęć mniejsza IV, herbowa ${ }^{259}$, potwierdzona w użyciu W $1765 \mathrm{r}$.

3. Or.: AP Wrocław, Rep. 91, nr 1262, s. 5.

5. $\mathrm{G}$ (uillelmus) / $\mathrm{A}($ bbas $) \mathrm{L}($ ubensis $)$

Inicjały majuskułą $\mathrm{w}$ polu pieczęci.

6. W polu pieczęci herb opactwa (na tarczy w kartuszu dzielonej w krzyż, pośrodku głowa św. Jana Chrzciciela na misie, w polu drugim i piątym szachowany dwurzędowy skos skrzyżowany z pastorałem, w polu trzecim i czwartym wspięty lew za kratą, nad kartuszem infuła, za nią pastorał o krzywaśni skierowanej do wewnątrz), zwieńczony kapeluszem rangowym między inicjałami ze sznurami, wiązaniami i chwostami po

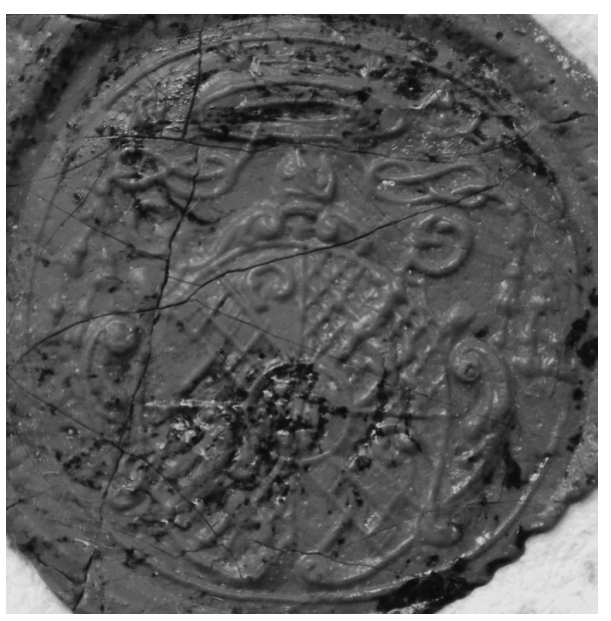
sześć w układzie 1, 2, 3. Na zewnątrz pola pieczęci cienkie obrzeżenie ciągłe.

7. Okrągła, ø $18 \mathrm{~mm}$.

8. Odcisk w laku czerwonym (1765).

9. Formuła sigillacyjna nieznana ${ }^{260}$.

\footnotetext{
${ }^{257} \mathrm{~W}$ dokumentach występują formuły koroboracyjne odnoszące się do podpisu i pieczęci opata i innych współpieczętujących $(1764,1766,1768)$ oraz podpisu i pieczęci (pieczęci i podpisów) opata i konwentu $(1766,1767)$. W dokumencie z $1766 \mathrm{r}$. brak formuły sigillacyjnej lub koroboracyjnej.

${ }^{258} \mathrm{~W}$ dokumencie występuje formuła koroboracyjna odnosząca się do podpisu i pieczęci opata, konwentu i innych współpieczętujących.

259 Pieczęć powstała w wyniku przerytowania starszego tłoka, omówionego pod nr. 48.

${ }^{260} \mathrm{~W}$ dokumencie występuje formuła koroboracyjna odnosząca się do pieczęci i podpisu opata i konwentu.
} 


\section{Nr 52}

\section{Opat Lukasz Springer (1769-1783)}

1. Pieczęć większa, piesza, potwierdzona w użyciu w 1782 r.

3. Or.: GStA PK, XVII. HA Schlesien, Rep. 91, Säkulariesierung Klöster/Stifter zu Leubus, nr 984.

5. SIGILLUM GUILL[E]LMI / ABBATIS LUBENSIS •

Napis majuskułą na wstęgach, między którymi widoczne ornamenty roślinne, legendę zamyka pojedynczy guz.

6. W polu pieczęci opat $\mathrm{w}$ kukulli, $\mathrm{z}$ mucetem na ramionach, $\mathrm{w}$ infule $\mathrm{w}$ typie pretiosa na głowie, $\mathrm{z}$ pastorałem o krzywaśni zwróconej na zewnątrz w prawej ręce i księgą w lewej. Nodus pastorału w formie trzech kul nierównej wielkości, krzywaśń ozdobiona żabkami na zewnętrznej krawędzi i motywem kuli w wolucie, poniżej środkowej kuli zawieszony jest panniselus. Opat stoi w renesansowej arkadzie, ustawionej na niewysokim postumencie, z kolumnami na profilowanych cokołach, trzonach z przewiązkami i podwójnymi kapitelami, nad którymi wznosi się profilowany łuk. W tle stojącego opata zaznacza się mniejsza edykuła (lub portal) zwieńczona konchą. Po bokach widać wysunięte cokoły, na których ustawiono dwa anioły w tunikach. Poniżej arkady herb opactwa (na tarczy w kartuszu dzielonej w krzyż, pośrodku głowa św. Jana Chrzciciela na misie, w polu drugim i piątym szachowany dwurzędowy skos skrzyżowany z pastorałem, w polu trzecim i czwartym wspięty lew za krata). Po wewnętrznej i zewnętrznej stronie wstęgi $z$ napisem grube obrzeżenie wieńcowe.

7. Ostroowalna, $73 \times 52 \mathrm{~mm}$.

8. Odcisk w wosku czerwonym w puszcze metalowej, z wieczkiem ozdobionym obrzeżeniem w formie żłobień z trzema rozetami pośrodku w pionie, przywieszony na pasku pergaminowym (1782).

9. Formuła sigillacyjna nieznana ${ }^{261}$.

\section{Nr 53}

\section{Opat Lukasz Springer (1769-1783)}

1. Pieczęć mniejsza I, herbowa, potwierdzona w użyciu w latach 1771-1780.

3. Or.: AP Wrocław, Rep. 91, nr 1274; nr 1292, s. 11; nr 1293, s. 8.

4. Kopia: GStA PK, VIII. HA Siegel, Wappen, Genealogie, Sammlung A. 32 III Siegelsammlung des Heroldsamtes (v. Nagler ?), Tafel $6^{262}$ (1 odcisk w laku czerwonym).

5. L(ucas) A(bbas) / L(ubensis)

Inicjały majuskułą w polu pieczęci, guz w dolnym indeksie po literze „L”.

6. W polu pieczęci herb opactwa (na tarczy w kartuszu dzielonej w krzyż, pośrodku głowa św. Jana Chrzciciela na misie, w polu drugim i piątym szachowany dwurzędowy skos skrzyżowany z pastorałem, w polu trzecim i czwartym wspięty lew za kratą, nad kartuszem infuła w typie pretiosa, za nią pastorał o krzywaśni skierowanej na zewnątrz), powyżej inicjały. Na zewnątrz pola pieczęci grube obrzeżenie ciągłe.

7. Owalna, 23 x $20 \mathrm{~mm}$.

8. Odciski w laku czerwonym (1771, 2 z 1780).

9. Formuła sigillacyjna nieznana ${ }^{263}$.

${ }^{261}$ Formuła sigillacyjna dokumentu, przy którym zachowała się publikowana pieczęć, odnosi się do pieczęci opata i większej konwentu.

262 Powyżej pieczęci piórem czarnym: Kloster Leubus / Lucas Springer.

${ }^{263} \mathrm{~W}$ dokumentach występują formuły koroboracyjne odnoszące się do podpisu i pieczęci (pieczęci i podpisu) opata oraz innych współpieczętujących. 


\section{Nr 54}

\section{Opat Lukasz Springer (1769-1783)}

1. Pieczęć mniejsza II, herbowa, potwierdzona w użyciu w latach 1772-1776.

3. Or.: AP Wrocław, Rep. 61, nr 360; Rep. 91, nr 1291.

5. L(ucas) A(bbas) / L(ubensis)

Inicjały majuskułą $\mathrm{w}$ polu pieczęci.

6. W polu pieczęci herb opactwa (na tarczy w kartuszu dzielonej w krzyż, pośrodku głowa św. Jana Chrzciciela na misie, w polu drugim i piątym szachowany dwurzędowy skos skrzyżowany z pastorałem, w polu trzecim i czwartym wspięty lew za kratą, nad kartuszem infuła, za nią pastorał o krzywaśni skierowanej do wewnątrz), po obu stronach infuły i pastorału inicjały, całość zwieńczona kapeluszem rangowym ze sznurami, wiązaniami i chwostami po sześć w układzie 1, 2, 3. Na zewnątrz pola pieczęci grube obrzeżenie wieńcowe.

7. Owalna, 29 x $26 \mathrm{~mm}$.

8. Odciski przez papier na podkładzie na podkładzie z wosku czerwonego $(1772,1776)$.

9. Formuła sigillacyjna nieznana ${ }^{264}$.

\section{Nr 55}

\section{Opat Franciszek Großpietsch (1783-1794)}

1. Pieczęć większa, piesza, potwierdzona w użyciu w 1793 r. 3. Or.: AP Wrocław, Oddział Legnica, Dokumenty cechowe miasta Legnicy, sygn. 163.

\section{SIGILLUM GUILLELMI / ABBAT[IS] LU[BENSIS •]}

Napis w otoku majuskułą na wstęgach, między którymi widoczne ornamenty roślinne.

6. W polu pieczęci opat $\mathrm{w}$ kukulli, $\mathrm{z}$ mucetem na ramionach, $\mathrm{w}$ infule w typie pretiosa na głowie, pastorałem o krzywaśni zwróconej na zewnątrz w prawej ręce i księgą w lewej. Nodus pastorału w formie trzech kul nierównej wielkości, krzywaśń ozdobiona żabkami na zewnętrznej krawędzi i motywem kuli w wolucie, poniżej środkowej kuli zawieszony jest panniselus. Opat stoi w renesansowej arkadzie, ustawionej na niewysokim postumencie, z kolumnami na profilowanych cokołach, trzonach z przewiązkami i podwójnymi kapitelami, nad którymi wznosi się profilowany łuk. W tle stojącego opata zaznacza się mniejsza edykuła (lub portal) zwieńczona konchą. Po bokach widać wysunięte cokoły, na których ustawiono dwa anioły w tunikach. Poniżej arkady herb opactwa (na tarczy w kartuszu dzielonej w krzyż, pośrodku głowa św. Jana Chrzciciela na misie, w polu drugim i piątym szachowany dwurzędowy

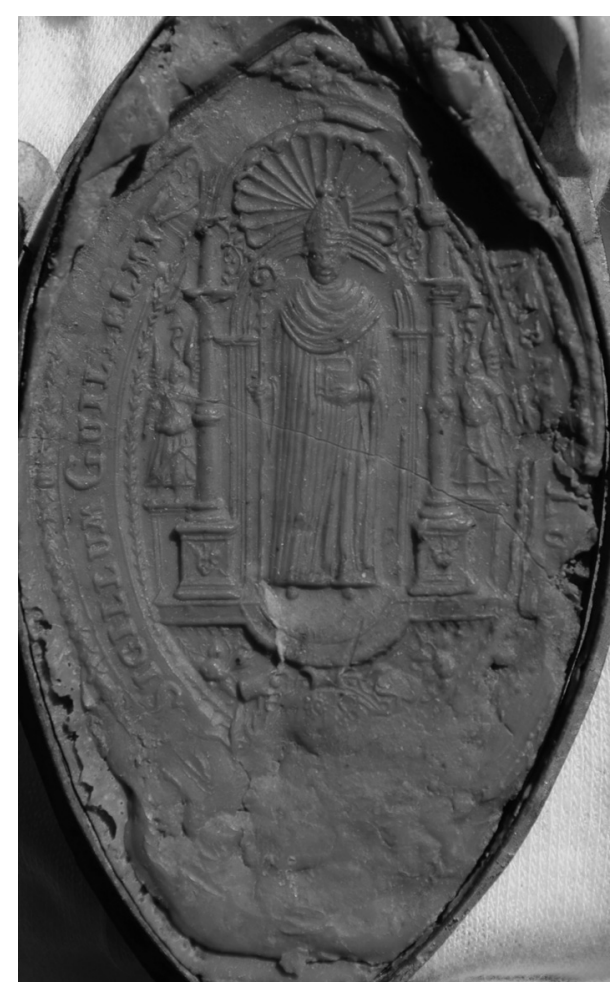
skos skrzyżowany z pastorałem, w polu trzecim i czwartym wspięty lew za kratą). Po wewnętrznej i zewnętrznej stronie wstęgi z napisem grube obrzeżenie wieńcowe.

${ }^{264} \mathrm{~W}$ dokumencie z 1772 r. występuje formuła koroboracyjna odnosząca się do podpisu i pieczęci opata, a w dokumencie z 1776 r. - do podpisów i pieczęci opata oraz magistratu miasta Wrocławia. 
7. Ostroowalna, ok. $72 \times 48 \mathrm{~mm}$.

8. Odcisk w wosku czerwonym w puszcze metalowej, z wieczkiem ozdobionym obrzeżeniem w formie żłobień z rozetą pośrodku, przywieszony na pasku pergaminowym (1793).

9. Formuła sigillacyjna nieznana ${ }^{265}$.

\section{Nr 56}

\section{Opat Franciszek Großpietsch (1783-1794)}

1. Pieczęć mniejsza I, herbowa, potwierdzona w użyciu w latach 1786-1787.

3. Or.: AP Wrocław, Rep. 85, nr 386; Rep. 91, nr 1299, s. 47; nr 1300, s. 40.

5. F(ranciscus) $\mathrm{A}($ bbas $) / \mathrm{L}$ (ubensis)

Inicjały majuskułą $\mathrm{w}$ polu pieczęci.

6. W polu pieczęci herb opactwa (na tarczy w kartuszu dzielonej w krzyż, pośrodku głowa św. Jana Chrzciciela na misie, w polu drugim i piątym szachowany dwurzędowy skos skrzyżowany $z$ pastorałem, w polu trzecim i czwartym wspięty lew za kratą, nad kartuszem infuła, za nią pastorał o krzywaśni skierowanej do wewnątrz), po obu stronach infuły inicjały. $\mathrm{Na}$ zewnątrz pola pieczęci grube obrzeżenie ciągłe.

7. Okrągła, ø $18 \mathrm{~mm}$.

8. Odciski w laku czerwonym (2 z 1786, 1787)

9. Formuła sigillacyjna nieznana ${ }^{266}$.

\section{Nr 57}

\section{Opat Franciszek Großpietsch (1783-1794)}

1. Pieczęć mniejsza II, herbowa, potwierdzona w użyciu po $1787 \mathrm{r}$.

3. Or.: AP Wrocław, Rep. 91, nr 1296, s. 6.

5. $\mathrm{F}($ ranciscus $) \cdot \mathrm{A}($ bbas $) \cdot \mathrm{L}($ ubensis $)$

Inicjały majuskułą $\mathrm{w}$ polu pieczęci, przerywniki między inicjałami w formie pojedynczych guzów.

6. W polu pieczęci uskrzydlony anioł podtrzymuje kartusz, na którym herb urzędowy opata (na tarczy w kartuszu szachowany dwurzędowy skos skrzyżowany z pastorałem, na nich głowa św. Jana Chrzciciela na misie, pole tarczy wypełnia damaskinaż), powyżej inicjały. Na zewnątrz pola pieczęci dwa obrzeżenia cienkie ciągłe i zewnętrzne grube wieńcowe. 7. Owalna, $28 \times 27 \mathrm{~mm}$.

8. Odcisk przez papier na podkładzie z ciasta (po 1787).

9. Formuła sigillacyjna nieznana.

${ }^{265}$ Formuła sigillacyjna dokumentu, przy którym zachowała się publikowana pieczęć, odnosi się do pieczęci opata i konwentu.

${ }^{266} \mathrm{~W}$ dokumentach występują formuły koroboracyjne odnoszące się do podpisu i pieczęci opata, konwentu i innych współpieczętujących (2 z 1786). W dokumencie z 1787 r. występuje formuła koroboracyjna odnosząca się do podpisu i pieczęci opata. 


\section{Nr 58}

\section{Opat Franciszek Großpietsch (1783-1794)}

1. Pieczęć mniejsza III, herbowa, potwierdzona w użyciu w 1790 r.

3. Or.: AP Wrocław, Rep. 55, nr 285.

5. $\mathrm{F}$ (ranciscus) A(bbas) L(ubensis)

Inicjały majuskułą w polu pieczęci, guzy w dolnym indeksie po każdej literze na oznaczenie skrótu.

6. W polu pieczęci herb opactwa (na tarczy w kartuszu dzielonej w krzyż, pośrodku głowa św. Jana Chrzciciela na misie, w polu drugim i piątym szachowany dwurzędowy skos skrzyżowany z pastorałem, w polu trzecim i czwartym wspięty lew za kratą, nad kartuszem infuła w typie pretiosa, za nią pastorał o krzywaśni skierowanej na zewnątrz), po obu stronach infuły inicjały. Na zewnątrz pola pieczęci trzy obrzeżenia ciągłe, pojedyncze cienkie i dwa grube.

7. Owalna, $25 \times 22 \mathrm{~mm}$.

8. Odcisk w laku czerwonym (1790).

9. Formuła sigillacyjna nieznana ${ }^{267}$.

\section{Nr 59}

\section{Opat Franciszek Großpietsch (1783-1794)}

1. Pieczęć mniejsza IV, herbowa, potwierdzona w użyciu w 1792 r.

3. Or.: GStA PK, I. HA Rep. 46 B Schlesien seit 1740, nr 168f, bpag.

5. $\mathrm{F}$ (ranciscus) A(bbas) L(ubensis)

Inicjały majuskułą $\mathrm{w}$ polu pieczęci.

6. W polu pieczęci uskrzydlony anioł podtrzymuje kartusz, na którym herb urzędowy opata (na tarczy w kartuszu szachowany dwurzędowy skos skrzyżowany z pastorałem, na nich głowa św. Jana Chrzciciela na misie), powyżej inicjały. Na zewnątrz pola pieczęci grube obrzeżenie wieńcowe.

7. Owalna, $31 \times 28 \mathrm{~mm}$.

8. Odcisk w laku czerwonym (1792).

9. Formuła sigillacyjna nieznana.

\section{Nr 60}

\section{Opat Gabriel Otto (1794-1810)}

1. Pieczęć herbowa I (?), potwierdzona w użyciu w $1810 \mathrm{r}$.

2. Tłok: zaginiony, przechowywany do 1945 r. w nieistniejącym obecnie Śląskim Muzeum Rzemiosła Artystycznego i Starożytności we Wrocławiu (Schlesisches Museum für Kunstgewerbe und Altertümer).

3. Or.: AA Wrocław, sygn. VB7w, bpag.; AP Wrocław, Rep. 83, nr 1201.

4. Kopia: GStA PK, VIII. HA Siegel, Wappen, Genealogie, Sammlung I 22 Siegelsammlung aufgehobener Stifter und Klöster in Schlesien, t. 1, k. 3 (1 odcisk w laku czerwonym) ${ }^{268}$; t. 2, bpag. (1 odcisk w laku czerwonym) ${ }^{269}$; GStA PK, VIII. HA Siegel, Wappen, Genealogie, Sammlung A. 57 Sammlung Dr. Adolf Randow, Tafel 110, nr 60270; MN Wrocław, Dział Numizmatyczno-Sfragistyczny, Inwentarz

\footnotetext{
267 Występuje formuła koroboracyjna odnosząca się do podpisów i pieczęci opata i konwentu.

${ }^{268}$ W górnym fragmencie karty napis ciemnym piórem: 13. Stück, vom Fürstlichen Cistercienser Stift zu Leubus.

${ }^{269}$ Powyżej pieczęci napis ciemnym piórem: 13. Stück, vom Cistercienser Stift zu Leubus.

${ }^{270}$ Poniżej napis ciemnym piórem: [...] Abt v. Leubus.
} 
kartkowy, bez nr inw. ${ }^{271}$; $\mathrm{nr}$ inw. MNWr XIV-2537, k. 3272; nr inw. MNWr XIV-S-X-2331, MNWr XIV-S-X-2250273.

\section{5. * SIGILLUM ABBATIAE LUBENSIS}

Napis w otoku majuskułą, w podwójnej obwódce ciągłej, litery „A” i „E” w ligaturze, legendę rozpoczyna rozeta.

6. W polu pieczęci herb opactwa (na tarczy w kartuszu dzielonej w krzyż, pośrodku głowa św. Jana Chrzciciela na misie, w polu drugim i piątym szachowany dwurzędowy skos skrzyżowany z pastorałem, w polu trzecim i czwartym wspięty lew za kratą, nad kartuszem infuła w typie pretiosa, za nią pastorał o krzywaśni skierowanej na zewnątrz). Na zewnątrz pola pieczęci, po zewnętrznej stronie napisu, grube obrzeżenie ciągłe.

7. Owalna, $35 \times 28 \mathrm{~mm}$.

8. Zaginiony tlok był wykonany $\mathrm{z}$ jaspisu oraz hematytu i osadzony w uchwycie wykonanym $\mathrm{z}$ czerwonego złota ${ }^{274}$; odciski w laku czerwonym (2 z 1810).

9. Formuła sigillacyjna nieznana ${ }^{275}$.

10. Repr., opis: A. Hryniewicz, Trzy inwentarze śląskich typariuszy posekularyzacyjnych, „Roczniki Sztuki Śląskiej”, 25, 2016, s. 254.

\section{Nr 61}

\section{Opat Gabriel Otto (1794-1810)}

1. Pieczęć herbowa II (?), niepotwierdzona w użyciu²76.

2. Tłok: MN Wrocław, Dział Numizmatyczno-Sfragistyczny, nr inw. MNWr XIV-276.

4. Kopia: GStA PK, VIII. HA Siegel, Wappen, Genealogie, Sammlung I 22 Siegelsammlung aufgehobener Stifter und Klöster in Schlesien, t. 1, k. 3 (1 odcisk w laku czerwonym) ${ }^{277}$; t. 2, bpag. (1 odcisk w laku czerwonym) ${ }^{278}$; GStA PK, VIII. HA Siegel, Wappen, Genealogie, Sammlung I 35 Stenzelsche Sammlung, Kasten 4 (1 odcisk w laku czerwonym); MN Wrocław, Dział Numizmatyczno-Sfragistyczny, Inwentarz kartkowy, bez nr inw. ${ }^{279}$; $\mathrm{nr}$ inw. MNWr XIV-2537, k. $3^{280}$; nr inw. MNWr XIV-S-X-2343.

\section{5. * SIGILLUM ABBATIAE LUBENSIS}

Napis w otoku majuskułą, w obwódce wewnętrznej sznurowej i zewnętrznej perełkowej, litery „A” $\mathrm{i}$, ,E” w ligaturze, legendę rozpoczyna rozeta.

6. W polu pieczęci herb opactwa (na tarczy w kartuszu dzielonej w krzyż, pośrodku głowa św. Jana Chrzciciela na misie, w polu drugim i piątym szachowany dwurzędowy skos skrzyżowany z pastorałem, w polu trzecim i czwartym wspięty lew za kratą, nad kartuszem infuła w typie pretiosa, za nią pastorał o krzywaśni skierowanej na zewnątrz).

7. Okrągła, ø $28 \mathrm{~mm}$, wys. tłoka: $107 \mathrm{~mm}$.

\footnotetext{
${ }^{271}$ W górnym fragmencie karty napis ciemnym piórem: 13. Stück vom Cistercienser Stift zu Leubus.

${ }^{272}$ W górnym fragmencie karty napis ciemnym piórem: 13. Stück, vom Fürstlichen Cistercienser Stift zu Leubus.

${ }^{273}$ Napisy ciemnym piórem, powyżej pieczęci: Leubus, obok późniejszy zapis: Lubiąż, poniżej pieczęci: Kloster // N - $10 \mathrm{~K}$ oraz po prawej stronie: G.d. H. v. S.

274 AP Wrocław, Kolekcja rękopisów Oddziału I, sygn. 369; zob. też komentarz w pierwszej części artykułu omawiający pieczęcie opata Gabriela Otto.

${ }_{275} \mathrm{~W}$ dokumentach występuje formuła koroboracyjna odnosząca się do pieczęci i podpisu opata i innych współpieczętujących.

276 Typariusz publikowanej pieczęci został przyporządkowany opatowi ze względu na podobieństwa legendy i ikonografii do analogicznych elementów pieczęci opisanej wyżej, pod nr. 60 .

277 W górnym fragmencie karty napis ciemnym piórem: 13. Stück, vom Fürstlichen Cistercienser Stift zu Leubus.

278 Powyżej pieczęci napis ciemnym piórem: 13. Stück, vom Cistercienser Stift zu Leubus.

${ }^{279}$ W górnym fragmencie karty napis ciemnym piórem: 13. Stück vom Cistercienser Stift zu Leubus.

${ }^{280}$ W górnym fragmencie karty napis ciemnym piórem: 13. Stück, vom Fürstlichen Cistercienser Stift zu Leubus.
} 
8. Płytka tłoka wykonana z mosiądzu, uchwyt ośmioboczny żelazny, na którym numer inwentarzowy, na uchwycie nacięcie w kształcie litery „X”.

9. Formuła sigillacyjna nieznana.

10. Repr., opis: B. Marcisz-Czapla, Tłoki pieczętne i pieczęcie kościelne z terenu Śląska, w: Gloria Deo. Rzemiosto sakralne, t. 2, red. M. Korżel-Kraśna, Wrocław 2010, s. 114, nr 96.

\section{From figural presentations to heraldic ones. Abbots of Lubiąż and their seals from the Late Middle Ages to the secularization of the monastery in 1810}

Summary: Abbot Andrzej Hoffmann (1498-1534), whose rule was at the turn of the Middle Ages and early modern era, used the great and small (secret) seal. From the time of Abbot Jan VI Hiller (1539-1552), the abbots had two additional seals (medium[?] and small) at their disposal, besides the great seal. The number of abbatial seals increased to four under Abbot Arnold Freiberger (1636-1672). Freiberger used a great seal and four small seals. An important fact has been established that the great seal was frequently re-engraved to update its keeper. In the early modern period, abbots used only two matrices of the great seal. The first seal matrix was made in the first half of the sixteenth century, commissioned by Abbot Jan V Franco (1534-1539) and was used until the early seventeenth century. The second matrix was prepared under Abbot Mateusz Rudolf (1607-1636) and remained in use until at least the late eighteenth century. This suggests the stability of the abbatial rule.

The conducted research makes it possible to argue that the seal images and inscriptions manifested the high position of the Lubiąz abbots. This enabled them to create their own identity within the community and outside. The image of St. Bernard of Clairvaux, placed on the great seals of Lubiąz abbots in the first half of the fifteenth century was replaced by the figure of the abbot in the first half of the sixteenth century. This emphasised the fact that it was a real person who wielded power. The abbot's representation was present on the seal until the end of the eighteenth century. New authority, and thus the abbot's special position, was manifested by obtaining pontificals which were presented on the abbot's seals from the times of Abbot Andrzej Hoffmann. Coats of arms were introduced on the Lubiąż abbatial seals in the first half of the sixteenth century. The abbots first used the coat of arms indicating their office, which intermittently appeared until the end of the eighteenth century; from the beginning of the seventeenth century it was accompanied by the abbey's coat of arms.

Nota o autorze: adiunkt w Instytucie Historii Uniwersytetu Śląskiego w Katowicach. Stypendysta Deutscher Akademischer Austauschdienst (DAAD 2007-2008, 2016) oraz Instytutu Herdera w Marburgu (2010). Zainteresowania badawcze: nauki pomocnicze historii ze szczególnym uwzględnieniem sfragistyki i heraldyki. Obecnie prowadzi badania nad pieczęciami i herbami cystersów na Śląsku od średniowiecza do początku XIX w.

Author: Assistant professor at the University of Silesia in Katowice, scholar of the German Academic Exchange Service (DAAD 2007-2008, 2016) and Herder Institute in Marburg (2010). His research interests include: the auxiliary sciences of history, especially sphragistics and heraldry. Currently he focuses on the Cistercian seals and coat of arms in Silesia from the Middle Ages till the beginning of the $19^{\text {th }}$ century.

Instytut Historii

Uniwersytet Śląski w Katowicach

ul. Bankowa 11

40-007 Katowice

e-mail: tkaluski@gmail.com

\section{Bibliografia}

\section{Źródla drukowane}

Aus dem ältesten Signaturbuche des Klosters Leubus, wyd. H. Grotefend, „Zeitschrift des Vereins für Geschichte und Alterthum Schlesiens", 12, 1874, nr 1, s. 202-207

Katalog duchowieństwa diecezjalnego i zakonnego na podstawie księgi święceń biskupów wroctawskich 1650 $-1810 / 12$, oprac. S. Jujeczka, H. Gerlic, W. Könighaus, Wrocław 2014 
Martin Sebastian Dittmans Chronik der Aebte von Leubus, wyd. W. Wattenbach, „Zeitschrift des Vereins für Geschichte und Alterthum Schlesiens", 1, 1856, s. 271-297

Monumenta Lubensia, wyd. W. Wattenbach, Breslau 1861

Statuta capitulorum generalium ordinis cisterciensis ab anno 1116 ad annum 1786, t. 6: Ab anno 1491 ad annum 1542, wyd. J.-M. Canivez, Louvain 1938; t. 7: Ab anno 1546 ad annum 1786, wyd. J.-M. Canivez, Louvain 1939

\section{Opracowania}

Bedos-Rezak B.M., When Ego Was Imago. Signs of Identity in the Middle Ages, Leiden-Boston 2011

France J., The Cistercians in Medieval Art, Stroud 1998

France J., Medieval Images of Saint Bernard of Clairvaux, Kalamazoo, Mich. 2007

Grüger H., Schlesisches Klosterbuch. Leubus, „Jahrbuch der Schlesischen Friedrich-Wilhelms-Universität zu Breslau", 22, 1981, s. 1-32

Harasimowicz J., Rola klasztorów cysterskich $w$ ksztaltowaniu się tożsamości kulturowej Śląska w dobie nowożytnej, w: Krzeszów uświęcony taska, red. H. Dziurla, K. Bobowski, Wrocław 1997, s. 154-170

Harc A., Harc L., Łużyniecka E., Lubiąż, w: Monasticon Cisterciense Poloniae, t. 2: Katalog męskich klasztorów cysterskich na ziemiach polskich i dawnej Rzeczpospolitej, red. A.M. Wyrwa, J. Strzelczyk, K. Kaczmarek, Poznań 1999, s. 202-217

Heslop T.A., Cistercian Seals in England and Wales, w: Cistercian Art and Architecture in the British Isles, red. Ch. Norton, D. Park, Cambridge 1986, s. 266-283

Hryniewicz A., Trzy inwentarze ślaskich typariuszy posekularyzacyjnych, „Roczniki Sztuki Śląskiej”, 25, 2016, s. $235-260$

Jamroziak E., The Cistercian Order in Medieval Europe 1090-1500, Abingdon 2013

Jażdżewski K.K., Lubiąż. Losy i kultura umysłowa śląskiego opactwa cystersów (1163-1642), Wrocław 1993

Kałuski T., Imago abbatis na pieczęciach śląskich cystersów w średniowieczu, w: Dzieje i kultura cystersów $w$ Polsce 2, red. M. Starzyński, D. Tabor, Kraków 2018, s. 395-415, 665-667

Könighaus W.P., Die Zisterzienserabtei Leubus in Schlesien von ihrer Gründung bis zum Ende des 15. Jahrhunderts, Wiesbaden 2004

Kościót klasztorny Wniebowzięcia NMP w Lubiążu. Historia, stan zachowania, koncepcja rewitalizacji, red. A. Kozieł, Wrocław 2010

Kozieł A., Michael Willmann i jego malarska pracownia, Wrocław 2013

Lejman B., ,Feminizm” programu tréściowego Sali Książęcej, w: Opactwo cystersów w Lubiażu i artyści, red. A. Kozieł, Wrocław 2008, s. 315-331

Marcisz-Czapla B., Tłoki pieczętne i pieczęcie kościelne z terenu Śląska, w: Gloria Deo. Rzemiosto sakralne, t. 2, red. M. Korżel-Kraśna, Wrocław 2010, s. 71-210

Slawik S., Die Kleidung der Cistercienser im Mittelalter. Weiße Mönche im braunen Kleid, „Analecta Cisterciensia”, 65, 2015, s. 134-151

Stróżyk P., Heraldyka opactwa cysterskiego w Leknie-Wagrowcu, w: Cystersi tekneńscy w krajobrazie kulturowym ziem polskich $w$ 850-lecie fundacji opactwa cysterskiego $w$ Leknie 1153-2003, red. A.M. Wyrwa, Łekno 2004, s. 89-104

Stróżyk P., Herby na pieczęciach cysterskich - wybrane zagadnienia, w: Pieczęcie herbowe - herby na pieczęciach, red. W. Drelicharz, Z. Piech, Warszawa 2011, s. 191-215

Stróżyk P., Pieczęcie cysterskie z opactwa w Łeknie-Wagrowcu (cz. II), „Studia i Materiały do Dziejów Pałuk”, 6, 2006, s. 139-153

Stróżyk P., Symbole władzy opata w przestrzeni klasztoru cysterskiego, w: Ingenio et humilitate. Studia z dziejów zakonu cystersów i Kościoła na ziemiach polskich, red. A.M. Wyrwa, Katowice 2007, s. 37-60

Wolnik F., Liturgia ślaskich cystersów w średniowieczu, Opole 2002

Wójcik M.L., Heraldyka klasztorów cysterskich na Ślasku, w: Polska heraldyka kościelna. Stan i perspektywy badań, red. K. Skupieński, A. Weiss, Warszawa 2004, s. 43-58

Wyrwa A.M., O stroju zakonnym cystersów w świetle wybranych źródet normatywnych i tradycji zakonnej. Zarys problemu, w: Klio viae et invia. Opuscula Marco Cetwiński dedicata, red. A. Odrzywolska-Kidawa, Warszawa 2010 , s. $547-564$ 